San Jose State University

SJSU ScholarWorks

Master's Theses

Master's Theses and Graduate Research

Spring 2019

\title{
Deformation, Sandstone Detrital Zircon Ages, and Provenance in and near the Eocene Leavenworth Fault Zone, Washington
}

Francesca Isabella Senes

San Jose State University

Follow this and additional works at: https://scholarworks.sjsu.edu/etd_theses

\section{Recommended Citation}

Senes, Francesca Isabella, "Deformation, Sandstone Detrital Zircon Ages, and Provenance in and near the Eocene Leavenworth Fault Zone, Washington" (2019). Master's Theses. 5018.

DOI: https://doi.org/10.31979/etd.ptrc-788e

https://scholarworks.sjsu.edu/etd_theses/5018

This Thesis is brought to you for free and open access by the Master's Theses and Graduate Research at SJSU ScholarWorks. It has been accepted for inclusion in Master's Theses by an authorized administrator of SJSU ScholarWorks. For more information, please contact scholarworks@sjsu.edu. 
DEFORMATION, SANDSTONE DETRITAL ZIRCON AGES, AND PROVENANCE IN AND NEAR THE EOCENE LEAVENWORTH FAULT ZONE, WASHINGTON

\author{
A Thesis \\ Presented to \\ The Faculty of the Department of Geology \\ San José State University \\ In Partial Fulfillment \\ of the Requirements for the Degree \\ Master of Science
}

by

Francesca I. Senes

May 2019 
(C) 2019

Francesca I. Senes 


\section{ALL RIGHTS RESERVED}

The Designated Thesis Committee Approves the Thesis Titled

DEFORMATION, SANDSTONE DETRITAL ZIRCON AGES, AND PROVENANCE IN AND NEAR THE EOCENE LEAVENWORTH FAULT ZONE, WASHINGTON

by

Francesca I. Senes

APPROVED FOR THE DEPARTMENT OF GEOLOGY

SAN JOSÉ STATE UNIVERSITY

May 2019
Dr. Robert Miller
Department of Geology
Dr. Jonathan Miller
Department of Geology
Dr. Dave Andersen
Department of Geology 


\begin{abstract}
DEFORMATION, SANDSTONE DETRITAL ZIRCON AGES, AND PROVENANCE IN AND NEAR THE EOCENE LEAVENWORTH FAULT ZONE, WASHINGTON.
\end{abstract}

by Francesca I. Senes

The North Cascades is an excellent area to study basins and strike-slip faults that formed during regional transtension. This structural, petrographic, and $\mathrm{U}-\mathrm{Pb}$ geochronological study focuses on the Eocene Leavenworth fault (LVF), which separates Eocene non-marine clastic rocks of the Chumstick Formation and older Swauk Formation. The LVF has been interpreted as a dextral strike-slip fault active during Chumstick deposition and as a reverse fault. Poles to beds $(n=207)$ in the Swauk Formation trend WNW, oblique to the $\sim 320^{\circ}$-striking LVF, and commonly dip SSW, defining a girdle and a fold axis plunging $4^{\circ}$ toward $297^{\circ}$. Beds $(n=50)$ in the Chumstick Formation trend NW and generally dip NE, and poles to beds define a fold axis plunging $13^{\circ}$ towards $306^{\circ}$. Overall, $70 \%$ of folds in the formations trend $\mathrm{NW}$ to $\mathrm{WNW},<30^{\circ}$ counter-clockwise to the main strand of the LVF, compatible with dextral transpression. Most faults in the Swauk and Chumstick formations strike $>45^{\circ}$ or $<30^{\circ}$ to the main strand of the LVF. Their movement sense is unknown. Source terranes for the Swauk Formation likely include the Cascades crystalline core to the $\mathrm{N}$ and $\mathrm{NE}$ and a combination of other relatively local sources to the N, NE, and SW. Detrital zircon maximum depositional ages in the Swauk Formation range from $67.2 \pm 1.9$ to $50.46 \pm$ 0.17 Ma, constraining the timing of deposition and early folding of the Swauk Formation. Distinctive $\sim 91$ Ma tonalitic clasts in Chumstick conglomerate were likely transported $\sim 20 \mathrm{~km}$ from their source by dextral slip of the Leavenworth fault zone. 


\section{ACKNOWLEDGMENTS}

I would like to take this opportunity to thank the people that made this thesis possible. First and foremost I want to thank my family, who have always encouraged and supported me. Especially my parents, who have devoted their lives to giving me the best possible future, and for this, I would like to dedicate this thesis to them. To Robert Duffala, your motivation and constant optimism has helped me greatly through this process. Thank you for being my support during times when everything seemed impossible. I would like to extend special gratitude and admiration to my thesis advisor, Bob Miller, for giving me the opportunity to work in the North Cascades, for his incredible mentorship and guidance through my graduate studies, and for his insight in the field and in the office. I value greatly all the time and effort you put into making this thesis possible. I thank my thesis committee members, Dave Andersen and Jonathan Miller, your doors were always open and I appreciate your insightful revisions and knowledge. I especially give thanks to my field assistant Natasha Budimirovic for her encouragement and companionship which kept me sane through my field work. I would like to express gratitude to my fellow geology graduate students and friends, especially Kelly Dustin and Katie Bryant. I knew I could go to you with any questions and you were always reliable. Thank you for listening to me practice my thesis defense and giving me creative feedback. Most importantly, I am thankful for your friendship. Lastly, I would like to thank Paul Umhoefer for his insightful ideas and discussions, and Melissa Gundersen and Mike Eddy for their collaboration throughout this project. This research was supported by the National Science Foundation grant EAR-1119358 to Robert Miller. 


\section{TABLE OF CONTENTS}

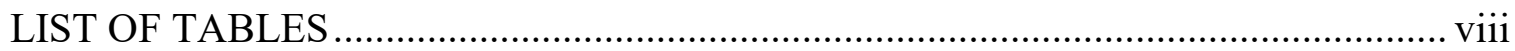

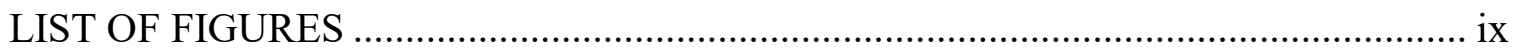

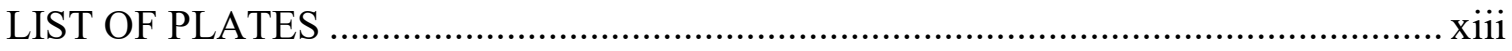

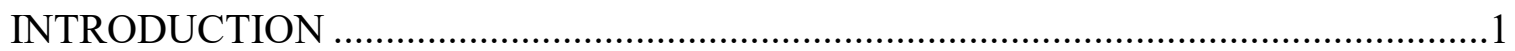

OVERVIEW OF THE MAIN ROCK UNITS IN THE LEAVENWORTH FAULT

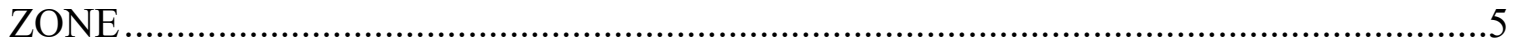

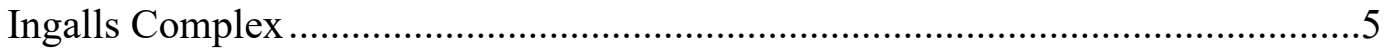

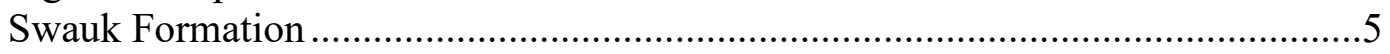

Teanaway Formation and Dikes ...................................................................

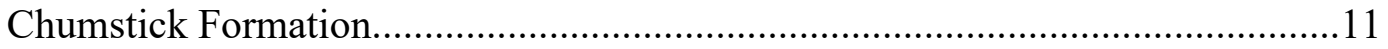

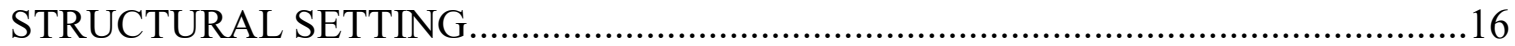

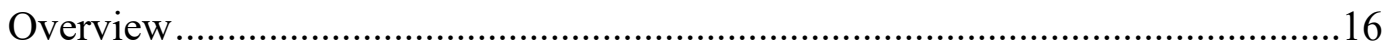

Leavenworth Fault Zone: Geometry and Models .................................................18

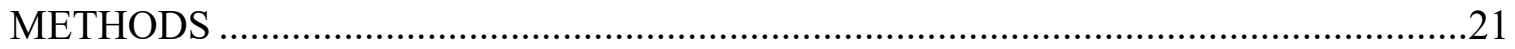

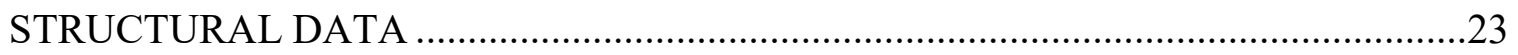

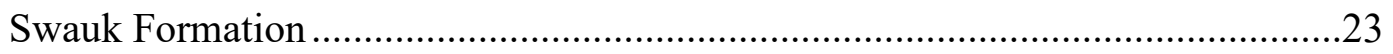

Chumstick Formation....................................................................................43

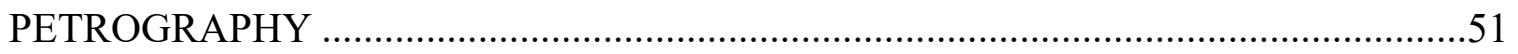

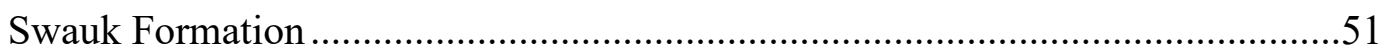

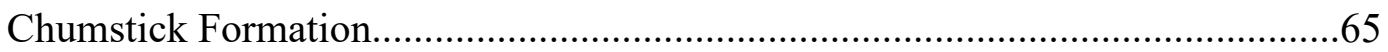

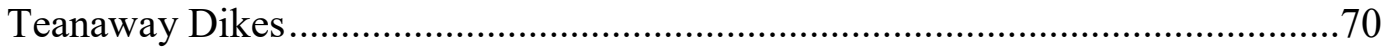

GEOCHRONOLOGY AND PROVENENCE OF UNITES ...........................................73

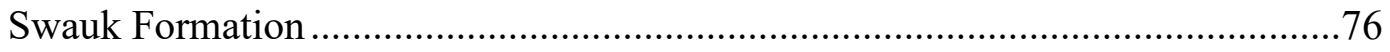

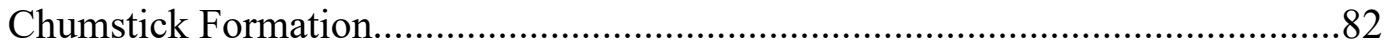

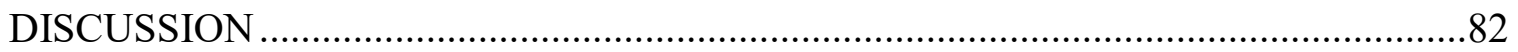

Summary and Analysis of the Structural Data of the Swauk Formation................83

Summary and Analysis of Structural Data of the Teanaway Dikes........................89

Summary and Analysis of Structural Data from the Chumstick Formation...........91

Summary and Analysis of Structural Data from the Swauk and Chumstick

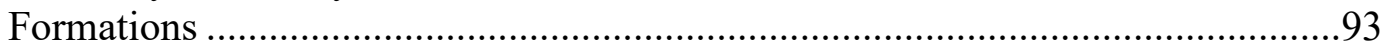

Summary and Analysis of Petrography of the Swauk and Chumstick Formations 
Geochronology and Provenance of Units

CONCLUSIONS.

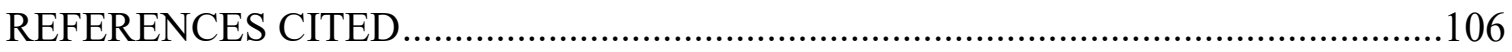

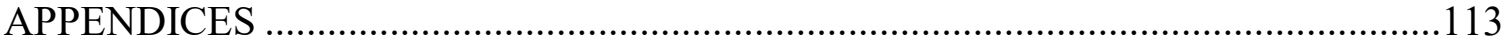

Appendix A: Geochronology Sample UTM Locations ....................................113

Appendix B: Sample point counting data ....................................................114 


\section{LIST OF TABLES}

Table 1. Stratigraphy of the Eastern Part of the Swauk Formation ...............................

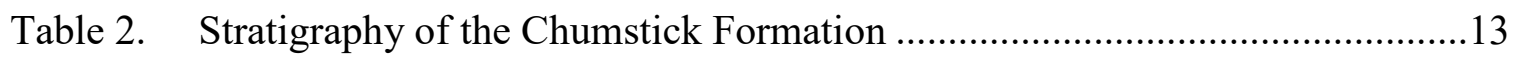

Table 3. Overview of the crystallization ages of plutons in the Cascades core.............75

Table 4. Overview of detrital zircon ages of metamorphic units in the Cascades

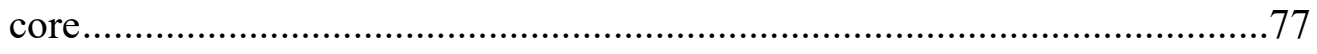

Table 5. QFL percentages based on point counts for sandstone samples in the Swauk and Chumstick formations......................................................................96

Table A.1. UTM locations of dated samples taken from the Swauk and Chumstick formations

Table B.1. Detailed mineral percentage modes based on point counts for all samples in the Swauk and Chumstick formations ....................................................114 


\section{LIST OF FIGURES}

Figure 1. Simplified geologic map emphasizing major Eocene structures of the Cascades core and adjacent areas

Figure 2. Map of North Cascades core with a polygon of the study area ......................4

Figure 3. Geologic map of the Tronsen Ridge area and surrounding area ....................8

Figure 4. Schematic stratigraphic sections of the Swauk Formation and Chumstick Formation, and their respective members and ages.....................................9

Figure 5. Tonalitic clasts in the Devil's Gulch Member, probably originating from the Mt. Stuart batholith

Figure 6. Map of faults and folds between the Leavenworth fault zone and the Entiat fault zone

Figure 7. Geologic map emphasizing bedding and foliation attitudes, and locations of cross sections in the Ruby Creek-Windmill Point and Tip-Top areas ...........24

Figure 8. Stereographic projection of poles to beds of the Ruby Creek-Windmill Point area

Figure 9. Outcrop showing a fault and fracturing in the Ruby Creek-Windmill Point area

Figure 10. Geologic map emphasizing orientations of faults in the Ruby CreekWindmill Point and Tip-Top areas

Figure 11. Stereographic projection of NW-striking faults and rakes (dots) in the Ruby Creek-Windmill Point area

Figure 12. Stereographic projection of NE-striking faults and rakes (dots) in the Ruby Creek-Windmill Point area

Figure 13. Geologic map emphasizing dikes in the Ruby Creek-Windmill Point and Tip-Top areas

Figure 14. Stereographic projection of poles to dikes intruding the Swauk Formation .32

Figure 15. Outcrop exposing a contact of a Teanaway dike and Swauk sandstone in the Ruby Creek-Windmill Point area 
Figure 16. Stereographic projection of poles to beds in the Swauk Formation and Chumstick Formation in the Tip-Top area....

Figure 17. Stereographic projection of faults and rakes (dots) in the Tip-Top area .......36

Figure 18. Geologic map showing orientations of beds, and cross sections B-B' and C-

$\mathrm{C}^{\prime}$ in the Tronsen Ridge area.

Figure 19. Panoramic view looking east from U.S. Highway 97 of the lower and upper Tronsen Ridge members of the Swauk Formation ......................................38

Figure 20. Stereographic projection of poles to beds on Tronsen Ridge area ...............40

Figure 21. Geologic map emphasizing orientations of beds on Mission Ridge 41

Figure 22. Stereographic projection of poles to beds in the Swauk Formation and Chumstick Formation on Mission Ridge.

Figure 23. Stereographic projection of all poles to beds in the Swauk Formation

Figure 24. Stereographic projection of all poles to fault planes in the Swauk Formation.

Figure 25. Geologic map of orientations of beds and faults, and cross section D-D' in the Beehive Reservoir area. 46

Figure 26. Stereographic projection of faults and rakes (dots) in the Tip-Top area of the Chumstick Formation

Figure 27. Stereographic projection of poles to beds in the Beehive Reservoir area .....49

Figure 28. Stereographic projection of faults and rakes (dots) in the Beehive Reservoir area

Figure 29. Stereographic projection of all poles to beds in the Chumstick Formation ..52

Figure 30. Map of the field area showing the location of dated samples and samples petrographically analyzed

Figure 31. Ternary plots for Swauk Formation sandstones

Figure 32. Sample FS280 of the Swauk Formation in the Ruby Creek-Windmill Point area. 
Figure 33. Sample FS151 of the Swauk Formation between the Ruby Creek-Windmill Point area and Tronsen Ridge.....

Figure 34. Sample FS149 of the Swauk Formation between the Ruby Creek-Windmill Point area and Tronsen Ridge

Figure 35. Sample FS147 of the Swauk Formation between the Ruby Creek-Windmill

Point area and Tronsen Ridge....

Figure 36. Sample FS140 of the upper Tronsen Ridge Member of the Swauk Formation.

Figure 37. Sample FS145 of the upper Tronsen Ridge Member of the Swauk Formation.

Figure 38. Sample FS224 of the lower Tronsen Ridge Member of the Swauk Formation....

Figure 39. Sample FS224A of the lower Tronsen Ridge Member of the Swauk Formation .....

Figure 40. Sample FS13 of Devil's Gulch Member of the Chumstick Formation near Camas Creek.

Figure 41. Sample FS253 of the Chumstick Formation southwest of Beehive Reservoir

Figure 42. Photomicrographs of Teanaway dikes.

Figure 43. Geologic map emphasizing potential sources for Eocene clastic rocks and rocks in the Cascades core and adjacent units

Figure 44. Relative probability plot of detrital zircon ages with MDAs for all dated samples

Figure 45. Geologic map of the study area highlighting folds

Figure 46. Geologic map of the Ruby Creek-Windmill Point and Tip-Top areas highlighting faults

Figure 47. Geologic map of Gundersen's (2017) Domain 7 with respect to the study area and the Leavenworth fault zone. 
Figure 48. Geologic map showing detrital zircon sample locations in western, central, and eastern transects of Gundersen (2017) and this study

Figure 49. Kernal density plots of detrital zircon ages from 0-200 Ma in the western, central, and eastern transects through the Swauk Formation 


\section{LIST OF PLATES}

Plate 1. Geologic Map of the Leavenworth Fault Zone....................supplemental 


\section{INTRODUCTION}

The North Cascades of Washington is an excellent area to study basins and strike-slip faults that formed during regional transtension (Johnson, 1984; Evans, 1988). In this orogen, the Eocene collapse of the Cretaceous and Paleogene crystalline core of the North Cascades, a NW-striking plutonic and metamorphic complex that stretches from central Washington to southwestern British Columbia, overlapped rapid deposition in nonmarine, fault-bounded basins (Haugerud et al., 1991; Miller et al., 2016). Two of the major Eocene basins are the Swauk and the Chumstick basins. The thick clastic sediments of the Swauk basin were folded before these rocks were intruded by the Eocene (49.3 Ma) Teanaway dikes, which are associated with the basalt-dominated Teanaway Formation. The clastic sediments of the Chumstick Formation were deposited shortly following the intrusion of the Teanaway dikes (Tabor et al., 1982, 1984) (Fig. 1).

Major Paleogene high-angle faults that formed during transtension in the region are, from east to west, the Ross Lake fault, Entiat fault, Leavenworth fault, and Straight Creek fault (Fig. 1). They mostly trend NW, but the Straight Creek fault strikes north-south (Misch, 1966; Tabor et al., 1982, 1987). The Ross Lake fault zone is a complex structure with both Eocene normal slip and dextral strike-slip (Miller, 1994). For the most part, this fault separates high-grade gneisses and plutons from low-grade rocks (Misch, 1966). The Entiat fault strikes NW and in part separates the Chumstick basin from crystalline rocks. The Entiat fault also divides the two blocks that comprise the North Cascades core. Southwest of the fault is the Wenatchee block, which contains 96-88 Ma plutons and host rocks, and to the northeast are the 96-45 Ma plutons of the Chelan block, which intrude 


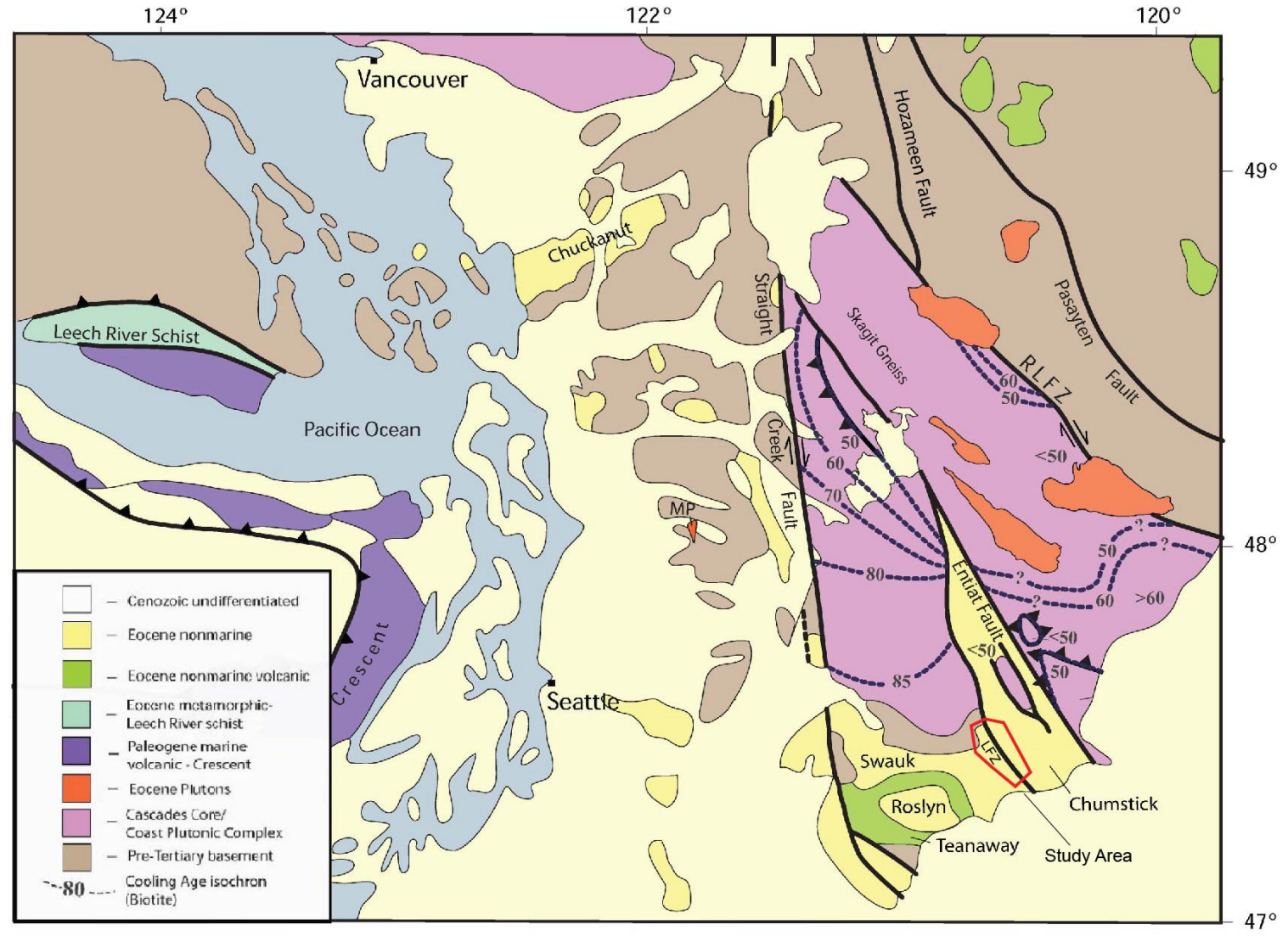

Figure 1. Simplified geologic map emphasizing major Eocene structures of the Cascades core and adjacent areas. Study area shown in red. MP $=$ Mount Pilchuck, LFZ = Leavenworth fault zone, and RLFZ =Ross Lake fault zone. Cooling ages in the Cascades core also shown. Figure modified from Miller et al. (2016). 
the Napeequa unit and Cascade River-Holden unit of the core (Tabor et al., 1987) (Fig. 2).

The Straight Creek fault is one of the most significant structures in the North Cascades (Fig. 1). It trends north-south and separates crystalline rocks to the east from low-grade, accreted oceanic and arc terranes to the west (Misch, 1966; Tabor et al., 1984). The Straight Creek fault dextrally offsets pre-Cenozoic rocks 80 to $190 \mathrm{~km}$, as well as the Eocene Swauk Formation from the Chuckanut Formation (e.g., Tabor et al., 1989; Umhoefer and Miller, 1996). Offset began by $48 \mathrm{Ma}$ in the south and ceased by 34 Ma (Tabor et al., 1984; Umhoefer and Miller, 1996).

East of the Straight Creek fault is the Leavenworth fault zone, a NW-striking fault with NW and N-S-striking segments (Fig. 1). The Leavenworth fault merges with the Entiat fault at the northern end of the Chumstick basin (Cater and Crowder, 1967). The Leavenworth fault zone is up to $\sim 5 \mathrm{~km}$ wide, and separates clastic rocks of the Chumstick Formation from those of the Swauk Formation in the southeast, and Chumstick Formation rocks from plutonic and metamorphic rocks of the Wenatchee block in the northwest (Tabor et al., 1987). The movement history of the fault is complex and widely debated. It is the main focus of this study and is discussed in further detail below. 


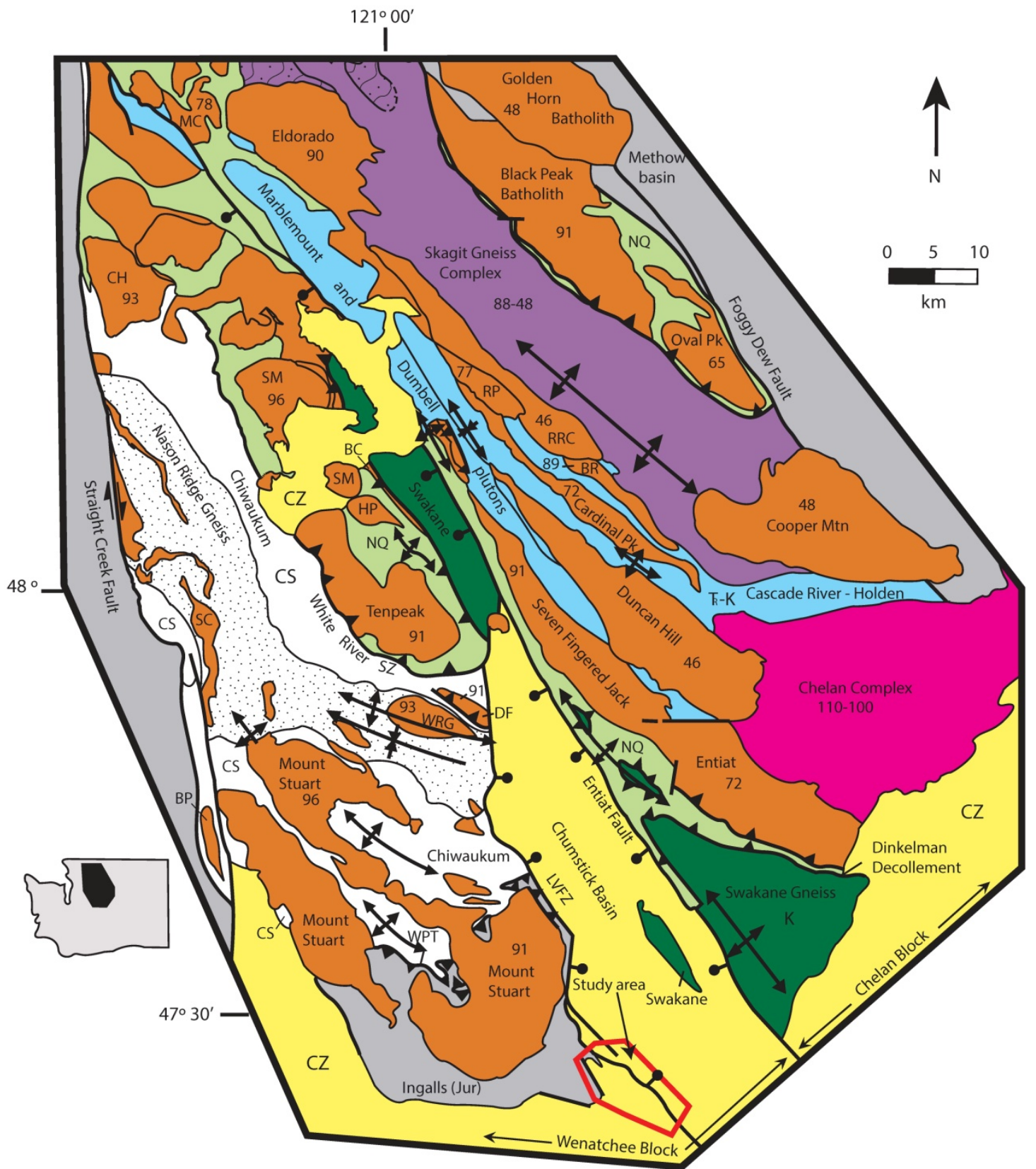

Figure 2. Map of North Cascades core with a polygon of the study area. LVFZLeavenworth fault zone. Note crystallization ages of the plutons. Unit abbreviations include: BC-Buck Creek Pass pluton; BP-Beckler Peak stock; BR-Bearcat Ridge Orthogneiss; CH-Chaval pluton; CP-Cardinal Peak pluton; CS-Chiwaukum Schist; CZCenozoic undifferentiated (mid-Eocene to Quaternary); DF-Dirtyface pluton; HP-High Pass pluton; MC-Marble Creek pluton; NQ-Napeequa unit; RRC-Railroad Creek pluton; RP-Riddle Peaks pluton; SC-Sloan Creek plutons; SM-Sulphur Mountain pluton; SZshear zone; WPT-Windy Pass thrust; WRG-Wenatchee Ridge Gneiss. Figure modified from Miller et al. (2009a). 


\section{OVERVIEW OF THE MAIN ROCK UNITS IN THE LEAVENWORTH FAULT ZONE}

\section{Ingalls Complex}

The mostly Late Jurassic Ingalls Complex is located west of the Leavenworth fault (Fig. 2). It was thrust onto the Chiwaukum Schist of the Cascade core in the Cretaceous, and wraps around the south end of the 96-91 Ma Mt. Stuart batholith (Southwick, 1974; Tabor et al., 1982; Miller, 1985). The ophiolite consists of tectonized ultramafic rocks in fault contact with a large spectrum of mafic rocks, and is overlain by pelagic sedimentary rocks (Tabor et al., 1982; Miller, 1985; Metzger et al., 2002; MacDonald et al., 2008). Metamorphic grade ranges from prehnite-pumpellyite facies in the south, to amphibolite facies in the north (Southwick, 1974; Tabor et al., 1982, 1987; Miller, 1985). Finegrained meta-sedimentary rocks are also present in the northeast (Tabor et al., 1982; Harper et al., 2003). Contacts within the Ingalls ophiolite strike east-west (Tabor et al., 1982; Miller, 1985) and major internal structures are two east-west-striking zones of serpentinite mélange (Miller, 1985).

\section{Swauk Formation}

The early Eocene Swauk Formation is located southwest of the Leavenworth fault and south of the Ingalls Complex and Mt. Stuart batholith (Fig. 2). To the west, it is bounded by the dextral Straight Creek fault (Tabor et al., 1982).

The Swauk Formation is estimated to be $\sim 8,000 \mathrm{~m}$ in thickness (Tabor et al., 2000), and is separated from the Teanaway Formation by an angular unconformity. The stratigraphy in the western part has been poorly studied, but the upper $\sim 2.5 \mathrm{~km}$ of the eastern part has been described in detail (Taylor, 1985). Deposits are of fluvial and 
lacustrine origin, and the main criteria used to distinguish the members of the Swauk Formation are the interbeds of sandstone and shale, the amount of conglomerate in each unit, the thickness of the conglomerate beds, and the size of the clasts in the conglomerate (Tabor et al., 1982; Taylor et al., 1988). Other criteria used in the eastern part of the formation include the overall thickness of beds and relative stratigraphic positions (Cheney and Hayman, 2009). The facies of the Swauk Formation in the eastern part of the basin that are relevant to this study are summarized in Table 1 (Tabor et al., 1982; Fraser, 1985; Taylor et al., 1988).

Feldspathic to lithofeldspathic, fine- to medium-grained sandstone dominates the Formation (Tabor et al., 1982). In the eastern part of the Swauk Formation, directly west of Tronsen Ridge (Fig. 3), sandstones are thin- to thick-bedded, have cross-beds, and are interbedded with siltstones and shales (Tabor et al., 1982). Pebbly sandstone and conglomerate are also present (Taylor et al., 1988; Cheney and Hayman, 2009) (Fig. 4).

The $\geq 1100$-m-thick Tronsen Ridge Member is located in the eastern part of the upper Swauk Formation (Fig. 3), and is particularly relevant for this study. It is mainly composed of shale, lithofeldspathic sandstone, and pebble conglomerate. Cross-bedding suggests a fluvial depositional environment. The Tronsen Ridge Member is interbedded with thick- to very thick-bedded, white arkosic sandstone to the northeast, also known as the sandstone facies of Red Hill, which is thought to be the uppermost part of the Swauk Formation (Tabor et al., 1982; Taylor et al, 1988).

The clastic rocks of the Swauk Formation interfinger with the $51.3 \pm 0.029$ Ma tuffs of the Silver Pass Member, a volcanic unit in the upper part of the Swauk Formation (Fig. 
Table 1: Stratigraphy of the Eastern Part of the Swauk Formation.

\begin{tabular}{|c|c|c|}
\hline Facies & Thickness & Lithology \\
\hline $\begin{array}{l}\text { Arkosic Sandstone } \\
\text { (sandstone facies of } \\
\text { Red Hill) }\end{array}$ & $\sim 390 \mathrm{~m}$ & $\begin{array}{l}\text { Poorly sorted, alternating coarse and fine members, } \\
\text { thick- to very thick-bedded, white sandstone } \\
\text { interbedded with darker shale of the Tronsen Ridge } \\
\text { facies. }\end{array}$ \\
\hline $\begin{array}{l}\text { Shale Facies of } \\
\text { Tronsen Ridge }\end{array}$ & $\geq 1100 \mathrm{~m}$ & $\begin{array}{l}\text { Thinly bedded, cross-bedded, dark grey or tan } \\
\text { micaceous lithofeldspathic sandstone, dark siltstone } \\
\text { and shale. Light-colored fine-grained sandstone and } \\
\text { siltstone. Rare thick bedded and cross-bedded } \\
\text { sandstone and pebble conglomerate. }\end{array}$ \\
\hline $\begin{array}{l}\text { Conglomerate and } \\
\text { Monolithic } \\
\text { Fanglomerate } \\
\text { Breccia }\end{array}$ & $\geq 900 \mathrm{~m}$ & $\begin{array}{l}\text { Lower and upper units separated by shale facies. } \\
\text { Boulder to pebble conglomerate, crudely bedded, } \\
\text { and trough cross-bedded. Clasts are predominately } \\
\text { granitic and metamorphic rock. Pebble dominated } \\
\text { debris-flow deposits. }\end{array}$ \\
\hline
\end{tabular}

Note: Lithology descriptions from Tabor et al. (1982), Fraser (1985), and Taylor et al. (1988). 

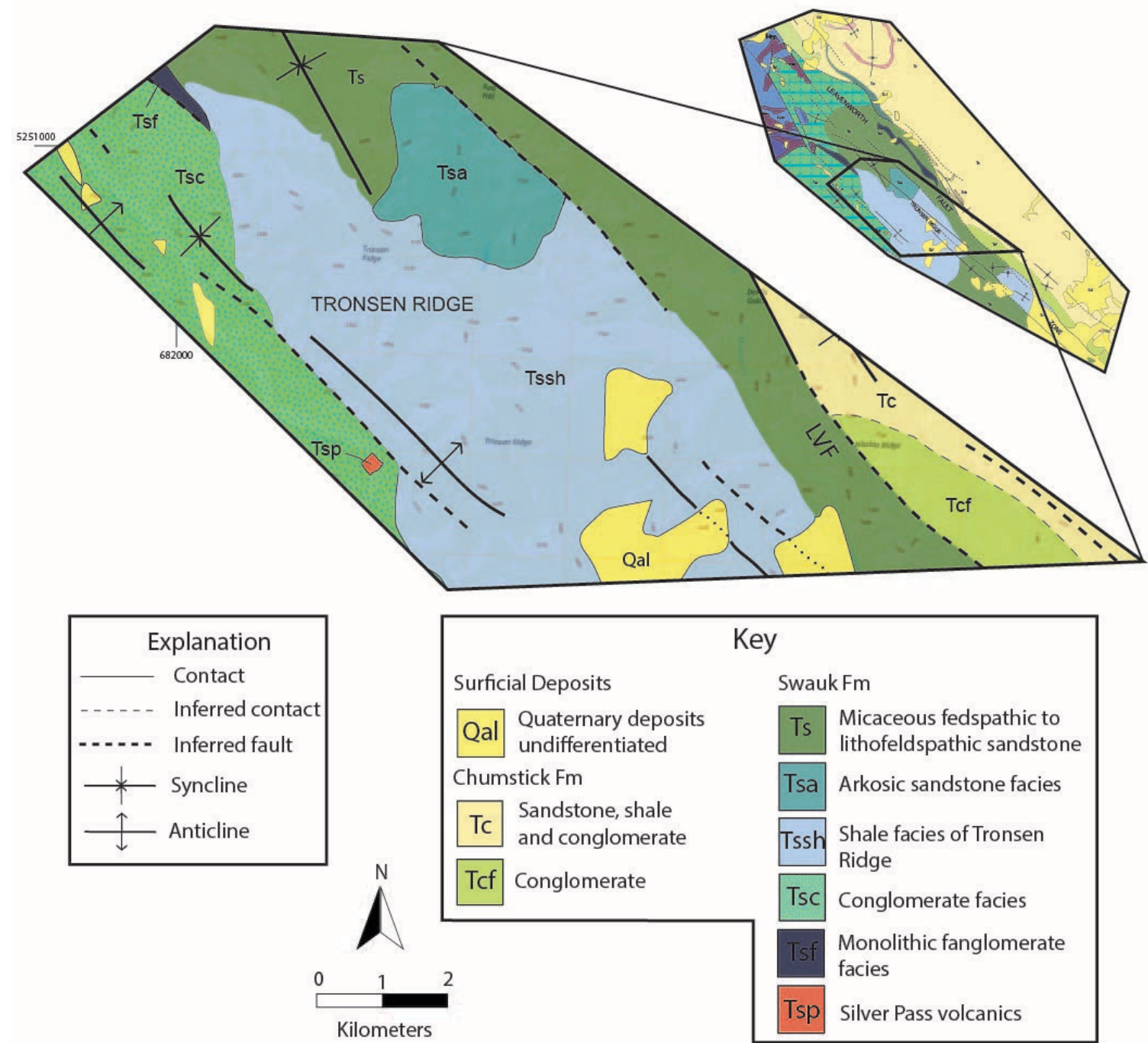

Figure 3. Geologic map of the Tronsen Ridge area and surrounding area. Units, contacts, and folds are taken from Tabor et al. (1982). LVF=Leavenworth fault. 

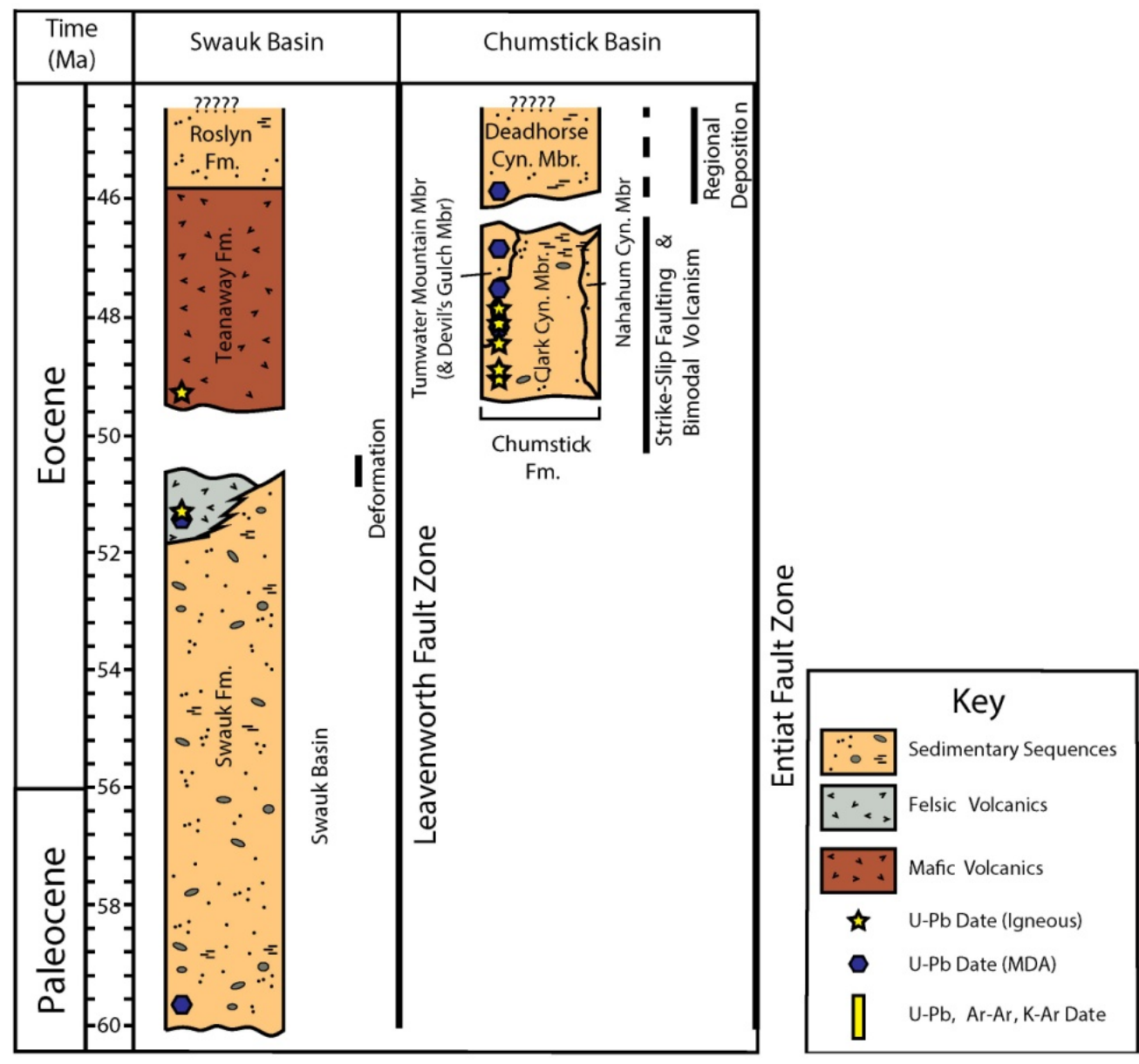

Figure 4. Schematic stratigraphic sections of the Swauk Formation and Chumstick Formation, and their respective members and ages. Modified from Eddy et al. (2016). 
4) (Tabor et al., 1982, 2000; Eddy et al., 2016). This member consists of andesitic and rhyolitic tuffs interbedded with clastic rocks (Tabor et al., 1982).

The eastern part of the Swauk Formation is openly to tightly folded, with fold wavelengths of $100 \mathrm{~m}$ to $2 \mathrm{~km}$ and steep axial planes (Tabor et al., 1982; Doran, 2009). Folds typically have N- to NW-trending axes (Tabor et al., 1984, 1989), at less than $45^{\circ}$ to the Entiat-Leavenworth fault system. Close to Tronsen Ridge, E-W-trending folds in the Swauk Formation have sinuous axial traces (Cheney and Hayman, 2009). Mafic Teanaway dikes (49.3 Ma.) intrude the folds and help bracket the timing of the folding (Tabor et al., 1984; Eddy et al., 2016; Miller et al., 2016).

\section{Teanaway Formation and Dikes}

The Teanaway Formation is composed mostly of mafic lavas, but ranges to rhyolitic in composition (Clayton, 1973). These volcanic rocks accumulated after the Swauk Formation was deformed, uplifted and eroded, and their source may be a shield volcano in the southwestern part of the outcrop belt (Clayton, 1973; Tabor et al., 1982). A flow in the eastern part of the Teanaway outcrop belt is $49.341 \pm 0.033 \mathrm{Ma}$ (Eddy et al., 2016).

The Teanaway dikes are a swarm of basaltic dikes that intrude the Swauk Formation and are presumably the same age as the Teanaway lavas (Foster, 1958; Tabor et al., 1982; Doran, 2009; Eddy et al., 2016) (Fig. 4). They extend over $75 \mathrm{~km}$ from east to west and $18 \mathrm{~km}$ from north to south (Foster, 1958). Their thickness averages between 12 and $20 \mathrm{~m}$ (Doran, 2009). In the eastern part of the Swauk Formation, more than $85 \%$ of the dikes strike NE, with a mean orientation of $040^{\circ}$, a dip of $78^{\circ}$, and an average thickness of 14 m (Mendoza, 2008; Miller et al., 2016). The dike orientations in the east 
indicate sub-horizontal extension towards $310^{\circ} / 130^{\circ}$, which is sub-parallel to slightly counter-clockwise of the regional strike. These orientations are broadly similar to those in the western and central parts of the Swauk basin, where dikes strike NNE (Doran et al., 2009).

\section{Chumstick Formation}

The Chumstick Formation is bounded on the east by the high-angle Entiat fault and on the west by the Leavenworth fault (Tabor et al., 1982, 1987; Evans, 1994; Cheney and Hayman, 2009) (Fig. 4). High-precision U-Pb geochronology of the oldest tuff above the sediments constrains the depositional age of the western Chumstick Formation between 49.147- 47.847 Ma (Eddy et. al., 2016). The Formation is made up of perhaps as much as $12 \mathrm{~km}$ of fluvial and lacustrine rocks, consisting of micaceous arkosic sandstone, shale, and conglomerate, as well as numerous tuffs that are interbedded with the clastic rocks. The Chumstick Formation is also intruded by felsic dikes, and is unconformably overlain by the gently folded, Oligocene Wenatchee Formation (Gresens et al., 1981; Tabor et al., 1982; Evans, 1994). Sandstone in the Chumstick Formation is distinguished from that of the Swauk Formation, in that the Chumstick has generally coarser grains, is dominantly arkosic in composition, has abundant lags of pebbles in the sandstone, the presence of coal, numerous tuff layers, and the Devil's Gulch Member (Evans, 1994; Cheney and Hayman, 2009).

The Chumstick Formation is split into five stratigraphic members based on lithofacies associations, compositions, and sedimentological features: the Clark Canyon Member; Tumwater Mountain Member; which includes the Devil's Gulch Member; Nahahum 
Canyon Member; and Deadhorse Canyon Member (Evans, 1994). These are summarized in Table 2, and the Devil's Gulch Member, which is critical for interpretation of the Leavenworth fault, is described in more detail below.

The oldest part of the Chumstick Formation is the $\sim 8-8.5$-km-thick Clark Canyon Member, which extends to the eastern boundary of the Leavenworth fault zone (Evans, 1994; Donaghy, 2015). It is composed of fluvial conglomerate, sandstone and mudrock, and contains numerous interstratified tuffs, measuring from $30 \mathrm{~cm}-2 \mathrm{~m}$ in thickness, which are dated as 49.1 - 47.9 Ma (Eddy et al., 2016). The upper part of the Clark Canyon Member interfingers with the Tumwater Mountain Member (Evans, 1994).

The Tumwater Mountain Member is a narrow tabular body exposed directly east of the Leavenworth fault (Fig. 4). Its thickness measures up to $1 \mathrm{~km}$, and it is thickest between two northwest-trending strands of the fault zone. The member is composed of conglomerate, sandstone, and mudrock, but lacks the tuffs of the Clark Canyon Member (Evans, 1994; Donaghy, 2015). Proximal facies are more evident than in the Clark Canyon Member, and there is more soft-sediment deformation (Evans, 1994).

The Nahahum Canyon Member is $\sim 1.2-1.5-\mathrm{km}$-thick, is restricted to the eastern part of the Chumstick basin, and is not considered further (Gresens et al., 1981; Tabor et al.,

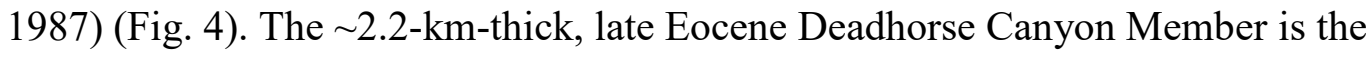
youngest part of the Chumstick Formation. It is limited to the northernmost and southernmost parts of the basin (Fig. 4). It is finer-grained, lacks tuffs, and has a higher concentration of felsic volcanic clasts than the underlying members (Evans, 1994).

The Devil's Gulch Member is 185-m-thick and is exposed along the northern and 
Table 2. Stratigraphy of the Chumstick Formation.

\begin{tabular}{|c|c|c|}
\hline Facies & Thickness & Lithology \\
\hline $\begin{array}{l}\text { Deadhorse Canyon } \\
\text { Member }\end{array}$ & $\sim 2.2 \mathrm{~km}$ & $\begin{array}{l}\text { Fine-grained sandstone and } \\
\text { mudstone, lacks tuff, and contains } \\
\text { distinctive felsic volcanic clasts. }\end{array}$ \\
\hline $\begin{array}{l}\text { Nahahum Canyon } \\
\text { Member }\end{array}$ & $\sim 1.2-1.5 \mathrm{~km}$ & Sandstone and mudstone. \\
\hline $\begin{array}{l}\text { Tumwater Mountain } \\
\text { Member }\end{array}$ & $<1 \mathrm{~km}$ & $\begin{array}{l}\text { Conglomerate, sandstone, and } \\
\text { mudrock; lacks tuffs, and is also } \\
\text { characterized by a coarse-grained } \\
\text { facies adjacent to the LVFZ. }\end{array}$ \\
\hline $\begin{array}{r}\text { Devil's Gulch } \\
\text { Member }\end{array}$ & $185 \mathrm{~m}$ & $\begin{array}{l}\text { Unsorted and unstratified } \\
\text { diamictite. Clasts are dominantly } \\
\text { tonalite. Ultramafic and phyllite } \\
\text { clasts are also found. }\end{array}$ \\
\hline $\begin{array}{l}\text { Clark Canyon } \\
\text { Member }\end{array}$ & $8-8.5 \mathrm{~km}$ & $\begin{array}{l}\text { Conglomerate, sandstone, } \\
\text { mudrocks, and } 18 \text { inter-stratified } \\
\text { airfall and ash-flow tuffs. The } \\
\text { lowest part is intruded by dikes, and } \\
\text { the upper part interfingers with the } \\
\text { Tumwater Mountain Member. It is } \\
\text { restricted to the western subbasin of } \\
\text { the Chumstick Formation. }\end{array}$ \\
\hline
\end{tabular}

Note: Lithology descriptions from Gresens et al. (1981), Tabor et al. (1982, 1987), Evans (1994), and Donaghy (2015). 
southern parts of the Leavenworth fault (Tabor et al., 1982; Taylor, 1988). The origin of the Devil's Gulch Member is controversial. It is the most distinctive unit in the Leavenworth fault zone (Tabor et al., 1982) (Tcf on Fig. 3), consisting of conglomeratic sandstone and unsorted and unstratified diamictite, with rounded clasts up to $150 \mathrm{~cm}$ in diameter (Tabor et al., 1982; Taylor et al., 1988). Clasts are mostly porphyritic, tonalitic, and monolithic (Fig. 5), but in places, ultramafic clasts predominate, and phyllites are also found (Cashman and Whetten, 1974; Tabor et. al., 1982; Cheney and Hayman, 2009). Zircons in clasts have been dated using laser ablation inductively coupled mass spectrometry, and are $91.7 \pm 1.5 \mathrm{Ma}$ to $90.6 \pm 1.5 \mathrm{Ma}$ (LaCasse, 2013). Potential sources for the coarse tonalitic clasts include the Mt. Stuart batholith, Tenpeak pluton, and Dirtyface pluton (Fig. 2). LaCasse (2013) concluded that, due to the closer proximity of the Mt. Stuart batholith, it is the most likely source.

Taylor et al. (1988) proposed that the member was originally deposited in the Swauk basin during uplift of the east side of the Leavenworth fault. Following a reverse in motion to west-side-up, Devil's Gulch blocks were downdropped into the Chumstick basin. In contrast, studies by Gresens (1981), Evans (1988), and Cheney and Hayman (2007) suggest that thick conglomerate sections of the Devil's Gulch Member represent some of the first sediments deposited in the Chumstick basin. Donaghy (2015) and Eddy et al. (2016) also consider it to be a marginal facies of the Chumstick Formation. I utilize the more recent interpretations, and consider the member part of the Chumstick Formation. 


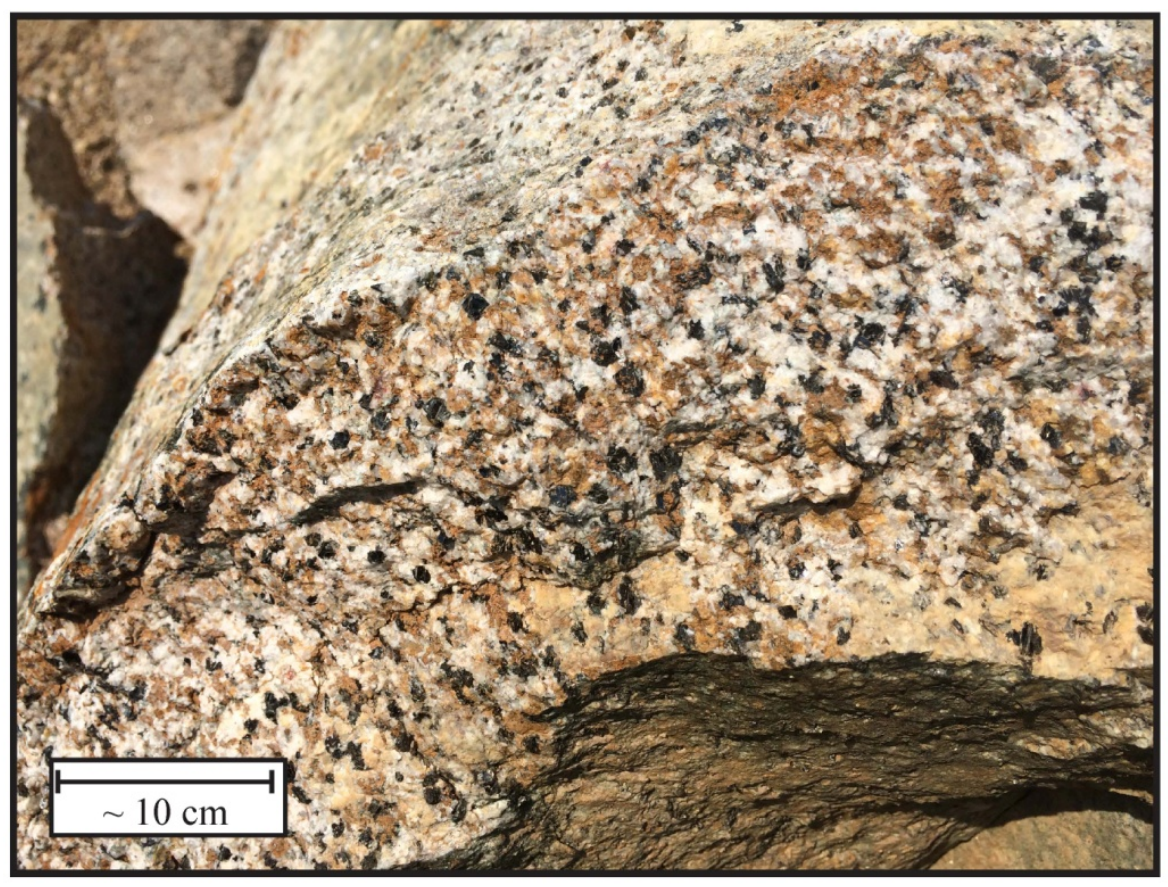

Figure 5. Tonalitic clasts in the Devil's Gulch Member, probably originating from the Mt. Stuart batholith. 


\section{STRUCTURAL SETTING}

\section{Overview}

The structural and depositional history of the Swauk Formation has been interpreted in different ways. Taylor et al. (1988) proposed that the Swauk Formation was deposited within a regional network of right-lateral strike-slip faults, and that its sedimentation patterns were most likely governed by dextral offset on the Straight Creek and Leavenworth fault systems. Evans (1994) suggested that the Swauk Formation was deposited in an extensional half graben, which he called the Swauk basin. Eddy et al. (2016) proposed that Swauk deposition largely predated the Leavenworth fault. Restoration of 100-150 km of dextral motion on the Straight Creek-Fraser fault places the Chuckanut and Swauk formations adjacent to one another (Fig. 1), and Eddy et al. (2016) inferred that these formations accumulated within a single depositional system between $\leq$ 59.9 and $>49.9$ Ma.

The Chumstick Formation was deposited in the Chumstick basin (Fig. 2), also referred to as the Chiwaukum graben (Evans, 1994) or the Chiwaukum structural low (Cheney and Heyman, 2009), which initiated prior to $49 \mathrm{Ma}$ (Eddy et al., 2016). The Eagle Creek fault divides the Chumstick basin (Fig. 6), forming a younger subbasin to the east, and the basement of the Chumstick Formation is the Cretaceous Swakane Biotite Gneiss, which crops out in the Eagle Creek anticline (Fig. 2) (Tabor et al., 1982; Evans, 1994). In the most recent model, the Chumstick basin formed as a strike-slip basin between the Leavenworth fault and the Entiat fault (Donaghy, 2015; Eddy et al., 2016). Evans (1994) proposed that the Chumstick basin was dominated by early extension and 


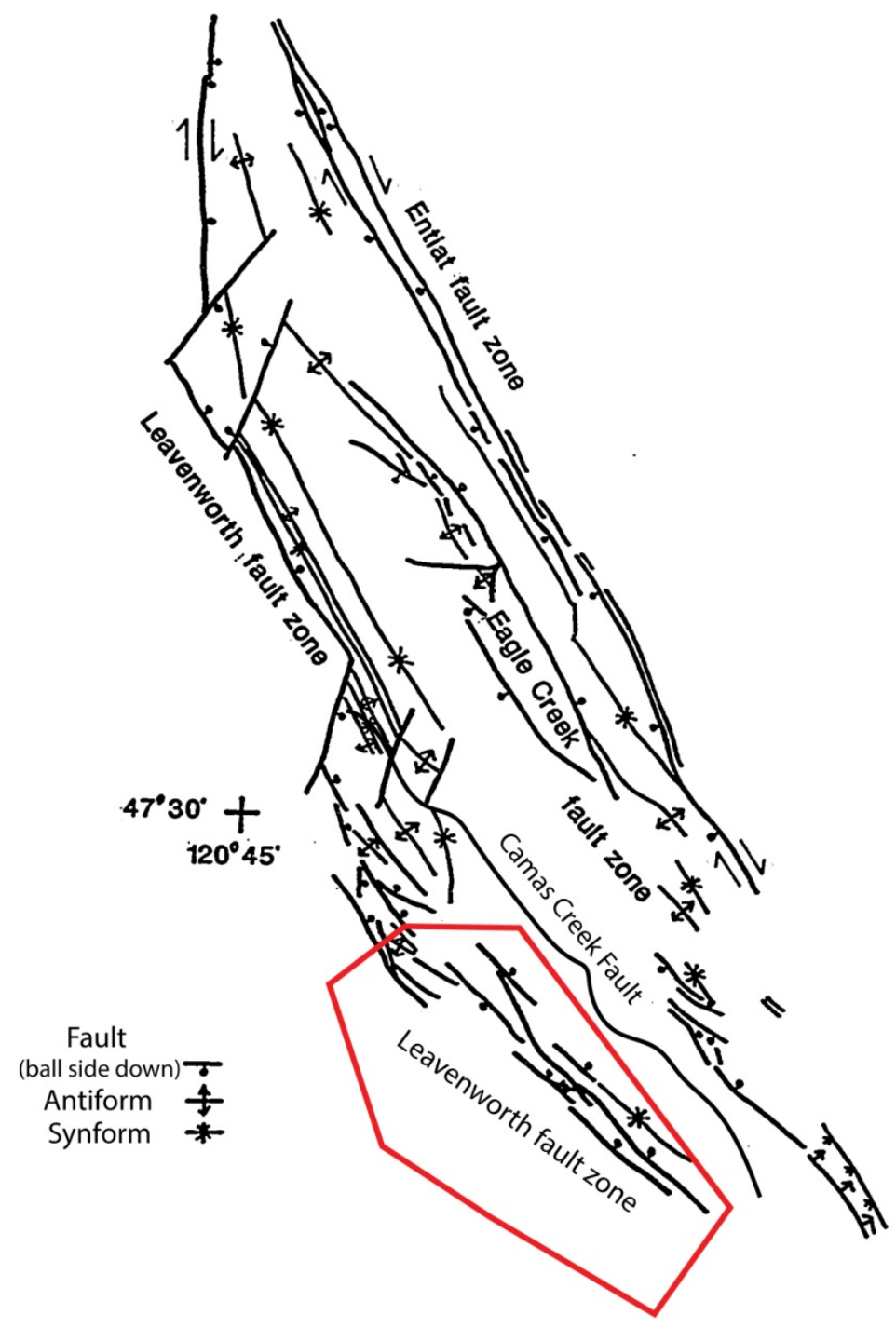

Figures 6. Map of faults and folds between the Leavenworth fault zone and the Entiat fault zone. Study area is shown in red. Figure modified from Evans (1988). 
later influenced by strike-slip motion. Folding during dextral transpression followed the deposition of the Chumstick Formation (Evans, 1994). In contrast, Cheney and Hayman (2009) contended that the structure of the Chumstrick rocks is dominated by high-angle reverse faults and that deposition was not influenced by strike-slip faulting.

The lower part of the Chumstick Formation is exposed in a homocline that dips $40^{\circ}$ west between the Leavenworth fault zone and the NW-striking Eagle Creek fault zone (Fig. 6). Northeast of the Eagle Creek fault zone is the doubly plunging Eagle Creek anticline (Tabor et al., 1982). The strata of the Clark Canyon Member, which lies between these fault zones, are also deformed into a series of small anticlines and synclines, which trend parallel to $40^{\circ}$ counter-clockwise to the Leavenworth fault and the Eagle Creek fault (Fig. 6) (Donaghy, 2015). The Eagle Creek fault ends in a set of splays to the WNW, whereas to the southeast it is buried by the Miocene Columbia River Basalt (Evans, 1994). Its orientation parallel to the Entiat fault, NW-SE trends of fold axes, and data from sedimentary rocks between the Eagle Creek and Entiat faults, provide evidence that the Eagle Creek fault is a major dextral oblique-slip fault (Evans, 1994).

\section{Leavenworth Fault Zone: Geometry and Models}

The movement history of the Leavenworth fault is controversial, as some have interpreted the fault to record strike-slip and others inferred that it is a reverse fault (e.g. Taylor et al., 1988; Evans et al., 1989; Evans, 1994; Cheney and Hayman, 2009). The timing of offset is also debated. Some workers concluded that subsidence of the Chumstick basin initiated at $\sim 48 \mathrm{Ma}$ (Tabor et al., 1984). In this model, subsidence began, and motion along the Leavenworth fault changed from east-side-up to west-side- 
up, and the active trace of the Leavenworth fault shifted up to $1 \mathrm{~km}$ westward, according to Taylor et al. (1988) and Evans (1994). Taylor et al. (1988) noted that alternating pulses of extension and deformation are common in strike-slip basins, and they proposed that the Swauk Formation formed in such a basin. Following deposition and folding, the Swauk Formation was intruded by the Teanaway dike swarm (Tabor et al., 1984).

Evans $(1994)$ and Tabor et al. $(1982,1984)$ concluded that initial movement was pre$44 \mathrm{Ma}$, and proposed a second episode of tectonic partitioning, deformation, and uplift of the Swauk basin, causing the reversal of movement sense (west-side-down to east-sidedown) of the Leavenworth fault at 44-42 Ma. This episode is marked by dextral faulting and folding with fold orientations consistent with north-south dextral shear on the Straight Creek fault, and NW-trending fold axes in the Chumstick Formation (Taylor et al., 1988) (Fig. 6). This event was followed by another episode of tectonic quiescence from $\sim$ 41-37 Ma, when deposition in the Chumstick Formation continued, and an episode of overtopping of the fault zone occurred. Between 37-34 Ma, NW-striking en enchelon faults formed, which suggest dextral transpression (Cashman and Whetten, 1974; Evans, 1988; Taylor et al., 1988).

Evans $(1988,1994)$ and other workers (Gresens, 1981; Taylor et al., 1988; La Casse, 2013) also proposed that offset of tonalitic fanglomerate deposits of the Devil's Gulch Member by approximately $30 \mathrm{~km}$ from a likely source resulted from dextral strike-slip on the Leavenworth fault.

In another model, the Leavenworth fault zone is a post-depositional, reverse fault (Cheney and Hayman, 2009). The evidence cited for this model is the northwest-trending 
Miocene folds in the Columbia River Basalt that can be traced into older rocks. Cheney and Hayman (2009) contended that the outcrop pattern of the Chumstick Formation is controlled by a regional Micocene syncline, rather than restricted to an Eocene basin. Cheney and Hayman (2009) suggested that folds oriented parallel to the Leavenworth fault formed during reverse motion along the fault. They also reported that slickensides near the Camas Creek fault, a strand of the Leavenworth fault in their model, are consistent with reverse motion (Fig. 6) (Cheney and Hayman, 2009).

Most recently, Eddy et al. (2016) determined high-precision zircon ages that supported the interpretation that the Straight Creek fault postdates the Swauk Formation. Accumulation on the then adjacent Swauk and Chuckanut formations occurred along Wor SW-flowing streams between $\leq 59.9$ and $51.3 \mathrm{Ma}$, which was followed by a reversal in paleoflow direction to the NE between 51.3 and $>49.9 \mathrm{Ma}$. Accumulation ended before 49.9 and was followed by NNE-SSW-directed shortening and basin inversion attributed to the accretion of Siletzia (Eddy et al., 2016; Miller at al., 2016). The oldest tuff age of 49.1 Ma in the Chumstick basin demonstrates that sediment accumulation there initiated close in time to the eruption of the lower Teanaway Formation (49.3 Ma.), and that the Chumstick rocks are younger than the Swauk Formation (Eddy et al., 2016).

High sediment accumulation rates of 2-7 m/k.y. for the Clark Canyon Member, and the rapid lateral movement of depocenters, suggest that the Chumstick Formation was deposited in a strike-slip basin (Eddy et al., 2016). The Nahahum Canyon Member of the Chumstick Formation provides further evidence for syndepositional faulting between $\leq 46.9$ and $>44.4 \mathrm{Ma}$, such as a coarse-grained facies adjacent to the Eagle Creek and 
Entiat faults, basin axial paleoflow, and soft sediment deformation (Evans, 1994).

\section{METHODS}

Geologic mapping and collection of structural data were conducted for six weeks during the summer of 2014. This project utilized previous 1:100,000 mapping done by Tabor et al. (1982), as well as 7.5 minute topographic maps $(1: 24,000)$ to conduct structural mapping of $\sim 50 \mathrm{~km}^{2}$ of both sides of the Leavenworth fault zone in more detail than had been previously done. Structures both outside and within the fault zone were mapped. I looked for systematic changes in strikes and dips of beds, rotation of beds, and orientations of faults and folds in both the Swauk and Chumstick formations. I also measured smaller brittle structures, such as slickensides, slickenside striae, small faults, and Riedel shears. Structural measurements were plotted on stereographic projections using Stereonet 9 (Allmendinger, 2017).

The extent of the Leavenworth fault zone was determined by mapping bed strikes and fold hinge lines at various distances from the main fault and then comparing those to regional orientations to assess whether they have been rotated. On the west side of the fault, orientations and thicknesses were determined for the Teanaway basaltic dikes that intrude the Swauk Formation. These dikes help evaluate the regional strain field and the potential effects of the Leavenworth fault in modifying the strain field.

Fourteen samples were made into thin sections at San Jose State University to determine their petrography. Nine of these are sandstones and were analyzed on the basis of mineral mode, grain size, sorting, rounding, sphericity, and microstructures, to determine their constituents and provenance. One low-grade metamorphic sample from 
the Ingalls ophiolite complex (FS13) was also analyzed for texture, and four Teanaway dikes were analyzed for modal mineralogy. Point counting analysis was conducted on the sandstones and the metamorphic sample. Three hundred points were counted for each thin section and spaced in an even grid of $4.0 \mathrm{~mm}$ using a Point-counting stage. The sandstone samples were then plotted on a QFL ternary diagram (Dickinson and Suczek 1979) comparing the relative amounts of quartz, feldspar, and lithic clasts for further classification and to determine provenance.

Five samples were prepared for $\mathrm{U} / \mathrm{Pb}$ detrital zircon geochronology using standard separation techniques. The equipment used at San Jose State University were a crushing mill and a steel disk mill (to reduce grain size). A Wilfley table was then used to separate the zircons from other minerals, followed by a Frantz magnetic separator, and two heavy liquid separations using Bromoform and Methyliodide. Finally, picking, mounting, and Back-Scattered Electron (BSE) imaging using Laser Ablation-Inductively Coupled Plasma Mass Spectrometry (LA-ICPMS) was performed at the LaserChron lab in Tucson, Arizona. Method $\mathrm{YC} 2 \sigma(3+)$ was used to determine maximum depositional ages (Dickinson and Gehrels, 2009). One sample (FS145) was re-evaluated by M.P. Eddy at the Massachusetts Institute of Technology by performing single zircon Chemical Abrasion-Isotope Dilution-Thermal Ionization Mass Spectrometry (CA-ID-TIMS) analysis in order to more precisely constrain the maximum depositional age of the Swauk deposition. 


\section{STRUCTURAL DATA}

\section{Swauk Formation}

Structural mapping of the Swauk Formation was conducted in four main areas: Ruby Creek-Windmill Point, Tip-Top, Tronsen Ridge, and Mission Ridge. These areas extend discontinuously for $\sim 25 \mathrm{~km}$ along the Leavenworth fault zone and as far as $5 \mathrm{~km}$ from the main trace of the fault, which has a general NW strike of $\sim 320^{\circ}$ in the study area (Fig. 1 and Plate 1).

The Ruby Creek-Windmill Point area (Fig. 7) is located east of the Ingalls Complex and is mostly bounded by two NW-striking strands of the Leavenworth fault, which are separated by $\sim 2-4 \mathrm{~km}$. In this area, the strike of the Leavenworth fault ranges from $\sim 300$ $320^{\circ}$. Bedding $(n=119)$ has a general NW strike and SW dip, with some beds dipping NE. There is no systematic change in strike in the Ruby Creek-Windmill Point area. Strikes average $168^{\circ}$, and dips range from $\sim 5-87^{\circ}$, with a mean of $\sim 52^{\circ} \mathrm{SW}$. Poles to beds $(\mathrm{n}=119)$ form a girdle indicating a fold axis plunging $004^{\circ}$ towards $299^{\circ}$. There is a significant scatter indicating non-cylindrical folding, and a clear maximum of $121^{\circ}, 60^{\circ}$ SW reflecting the dominant SW dips (Fig. 8). Folds $(\mathrm{n}=6)$ of $\sim 0.5-2.5 \mathrm{~km}$ wavelength have average trends of $292^{\circ}$, defined by bedding reversals. Fold interlimb angles in the Ruby Creek-Windmill Point area range from $\sim 33-60^{\circ}$, and line-length balancing assuming flexural-slip folding yields a total of $\sim 0.6-1.1 \mathrm{~km}$ of shortening (Fig. 7). Faults in the Ruby Creek-Windmill point area (Figs. 9 and 10) have relatively inconsistent strikes. Forty-nine faults were separated into NW-striking and NE-striking sets, and forty-three out of those forty-nine faults had slickensides and measurable rakes. 


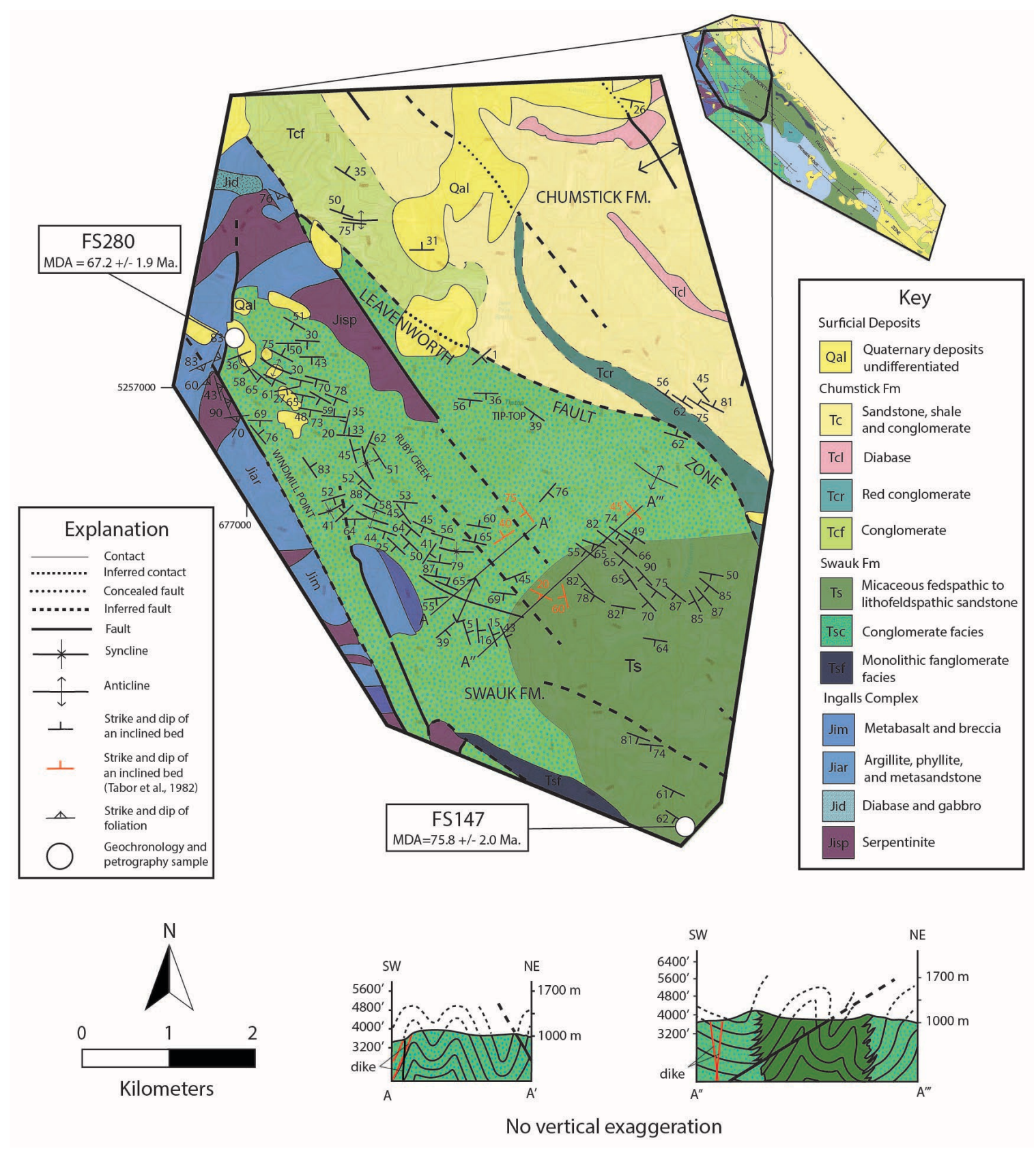

Figure 7. Geologic map emphasizing bedding and foliation attitudes, and locations of cross sections in the Ruby Creek-Windmill Point and Tip-Top areas. Not all structural data are shown. Thin lines in cross sections indicate traces of bedding, thick lines represent faults, and red lines represent dikes. Inset shows the location of the Ruby Creek-Windmill Point and Tip-Top transects within the study area. 


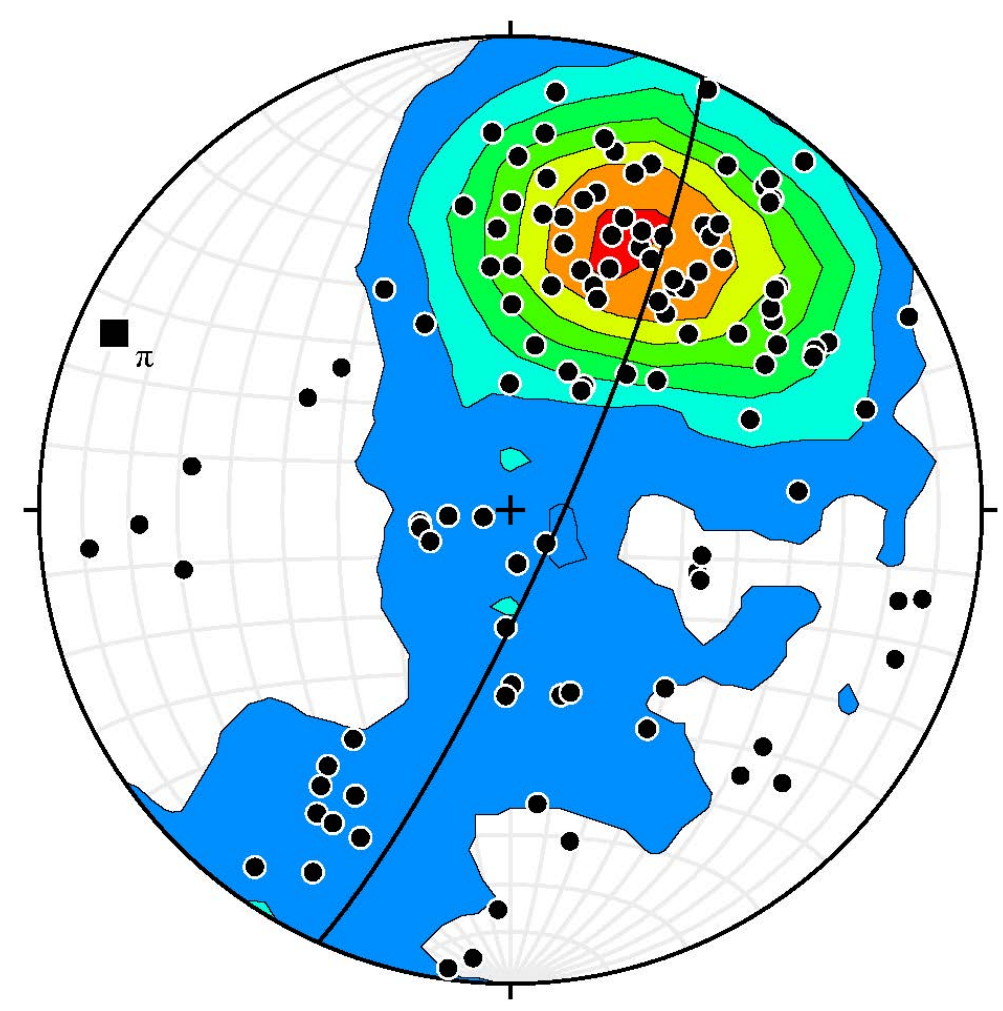

$\mathrm{n}=119$

Figure 8. Stereographic projection of poles to beds in the Ruby Creek-Windmill Point area. Contour interval of $2 \sigma$, using Kamb (1959) method. $\Pi$ axis $=004^{\circ}, 299^{\circ}$. Maximum of $121^{\circ}, 60^{\circ} \mathrm{SW}$. 


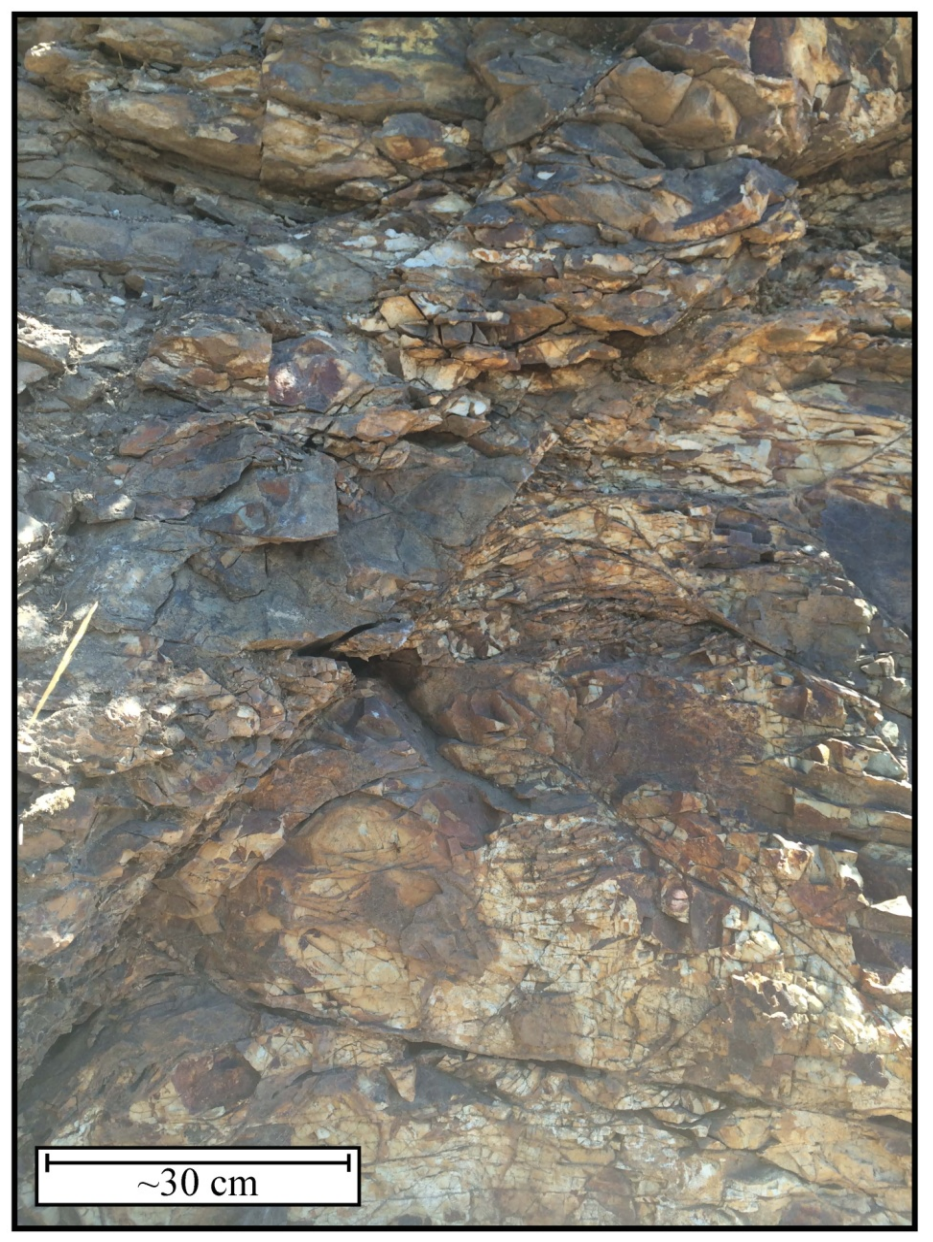

Figure 9. Outcrop showing a fault and fracturing in the Ruby Creek-Windmill Point area. 


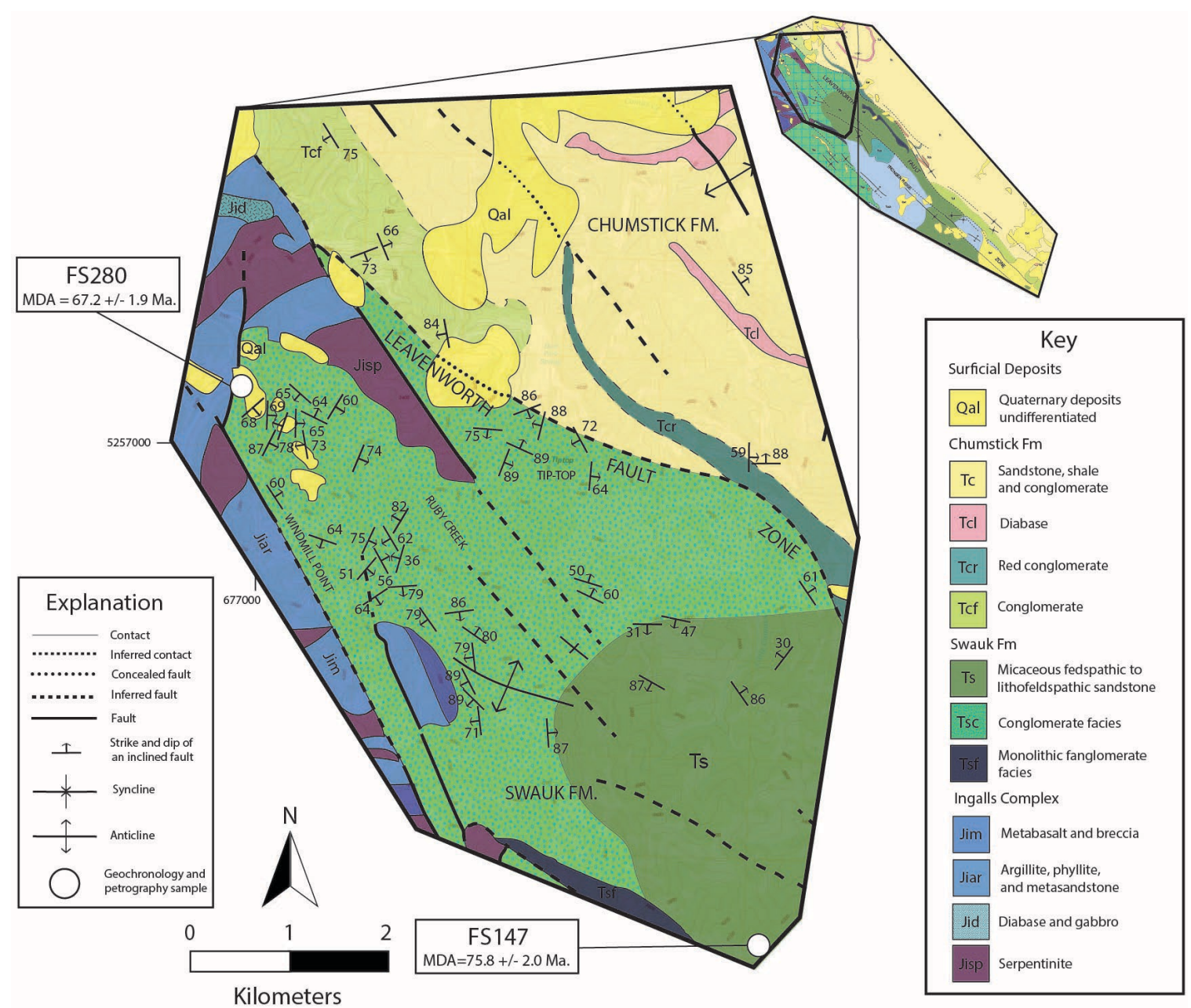

Figure 10. Geologic map emphasizing orientations of faults in the Ruby Creek-Windmill Point and Tip-Top areas. Not all faults are shown. 
NW-striking faults $(n=21)$ are moderately to generally steeply dipping (average of $72^{\circ}$ ), have an average strike of $332^{\circ}$, and a maximum of $331^{\circ}, 85^{\circ} \mathrm{NE}$. NE-striking faults $(n=28)$ are steeply dipping (average of $\left.73^{\circ}\right)$, have an average strike of $033^{\circ}$, and a maximum of $033^{\circ}, 79^{\circ} \mathrm{SE}$. In addition, 19 out of the $49 \mathrm{NW}$ - and NE-striking faults strike $>45^{\circ}$ clockwise $\left(005-045^{\circ}\right)$ from the main strand of the Leavenworth fault. Six of the 49 faults strike $31-40^{\circ}$ clockwise from the main fault $\left(356^{\circ}-360^{\circ}\right)$. Sixteen of the 49 faults strike $<30^{\circ}$ from the fault; half strike clockwise $\left(324^{\circ}-345^{\circ}\right)$ and the other half strike parallel and counter-clockwise $\left(301^{\circ}-320^{\circ}\right)$ from the fault.

Rakes of slickensides on the fault planes are scattered, but are mostly moderate to high (Fig. 11). Rakes in the NW-striking fault planes $(\mathrm{n}=19)$ average $81^{\circ}$ with a maximum of $83^{\circ}$ to the NW. Rakes in the NW quadrant are low to high and rakes in the SE quadrant are low to moderate. Overall, rakes on NW-striking faults show significant scatter, and $74 \%$ are $>45^{\circ}$. Rakes in the NE-striking fault planes $(\mathrm{n}=24)$ are mostly scattered and moderate (average of $40^{\circ}$ ) with a maximum of $43^{\circ}, 063^{\circ}$ (Fig. 12). Rakes in the NE quadrant are low to moderate and form minor clusters, and rakes in the SW quadrant are moderate to high, and show significant scatter and no clusters. Overall, fiftyfour per cent of rakes on NE-striking faults are $>45^{\circ}$.

Dikes intruding the Swauk Formation are concentrated in the Ruby Creek-Windmill Point area (Fig. 13). From southwest to northeast, and approaching the Leavenworth fault zone, most dikes ( $\mathrm{n}=19)$ appear to rotate by $\sim 80^{\circ}$ from NW-striking to NE-striking. Dikes have a mean strike of $\sim 209^{\circ}$, and dips range from $\sim 18-89^{\circ}$, with a mean dip of $75^{\circ} \mathrm{NW}$. Dikes have a maximum of $179^{\circ}, 87^{\circ} \mathrm{W}$ (Fig. 14). Dike thickness ranges from $\sim 2-34 \mathrm{~m}$, 


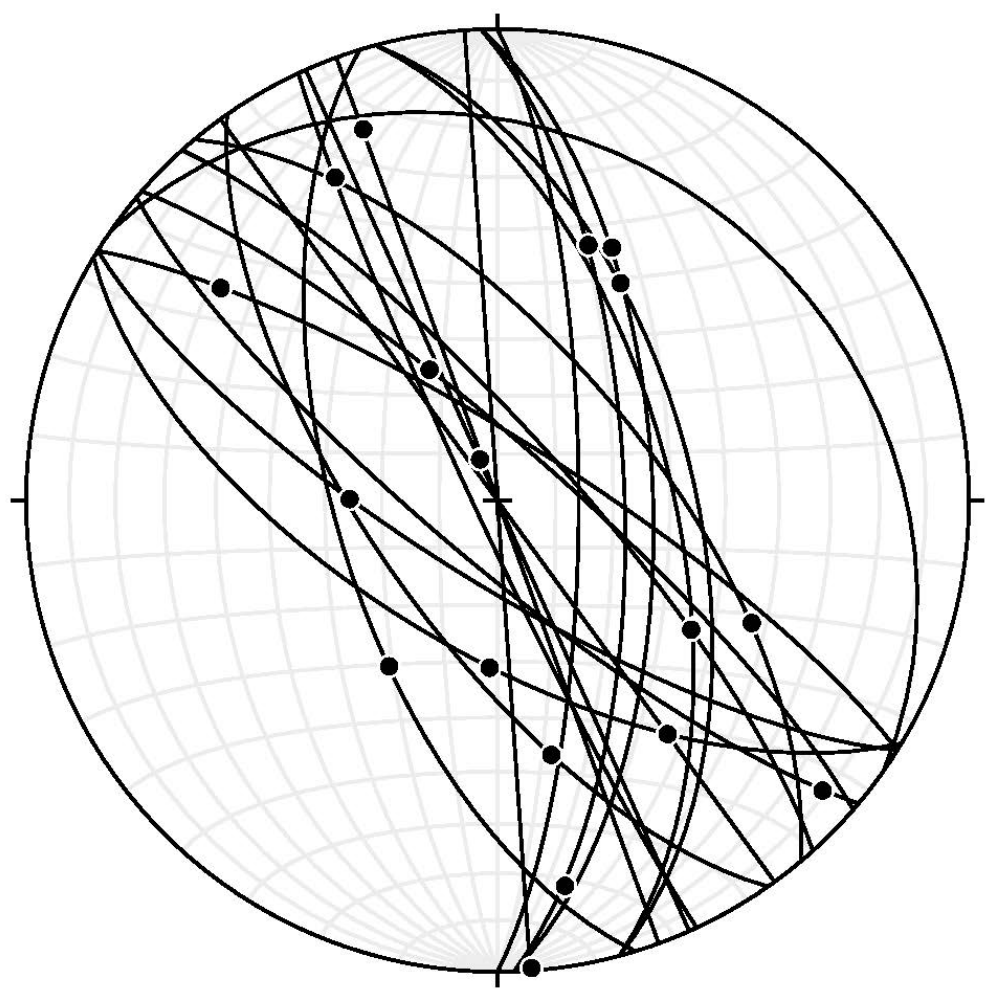

$\mathrm{n}=21$

Figure 11. Stereographic projection of NW-striking faults and rakes (dots) in the Ruby Creek-Windmill Point area. Two faults without rakes are also included. Maximum of faults is $331^{\circ}, 85^{\circ} \mathrm{NE}$. 


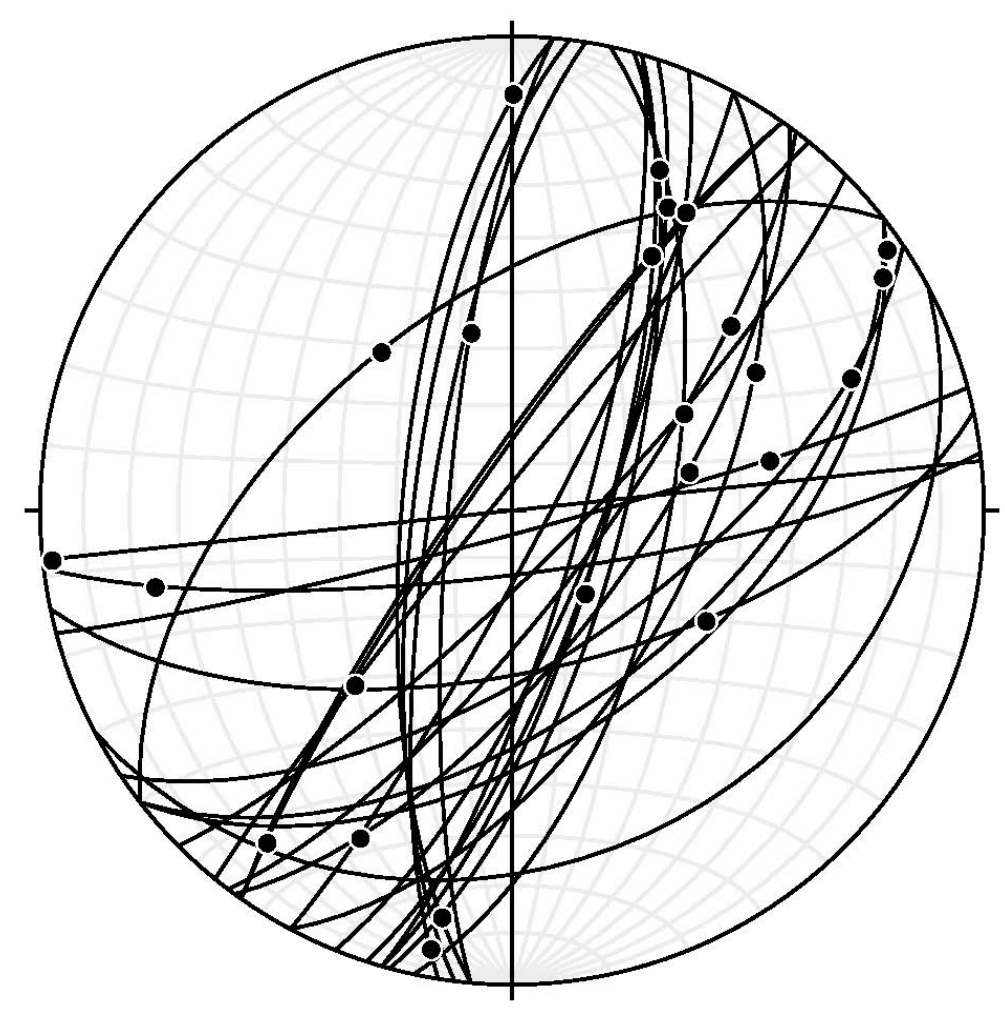

$\mathrm{n}=28$

Figure 12. Stereographic projection of NE-striking faults and rakes (dots) in the Ruby Creek-Windmill Point area. Faults without rakes $(n=4)$ are also included. Maximum of faults is $033^{\circ}, 79^{\circ} \mathrm{SE}$. 


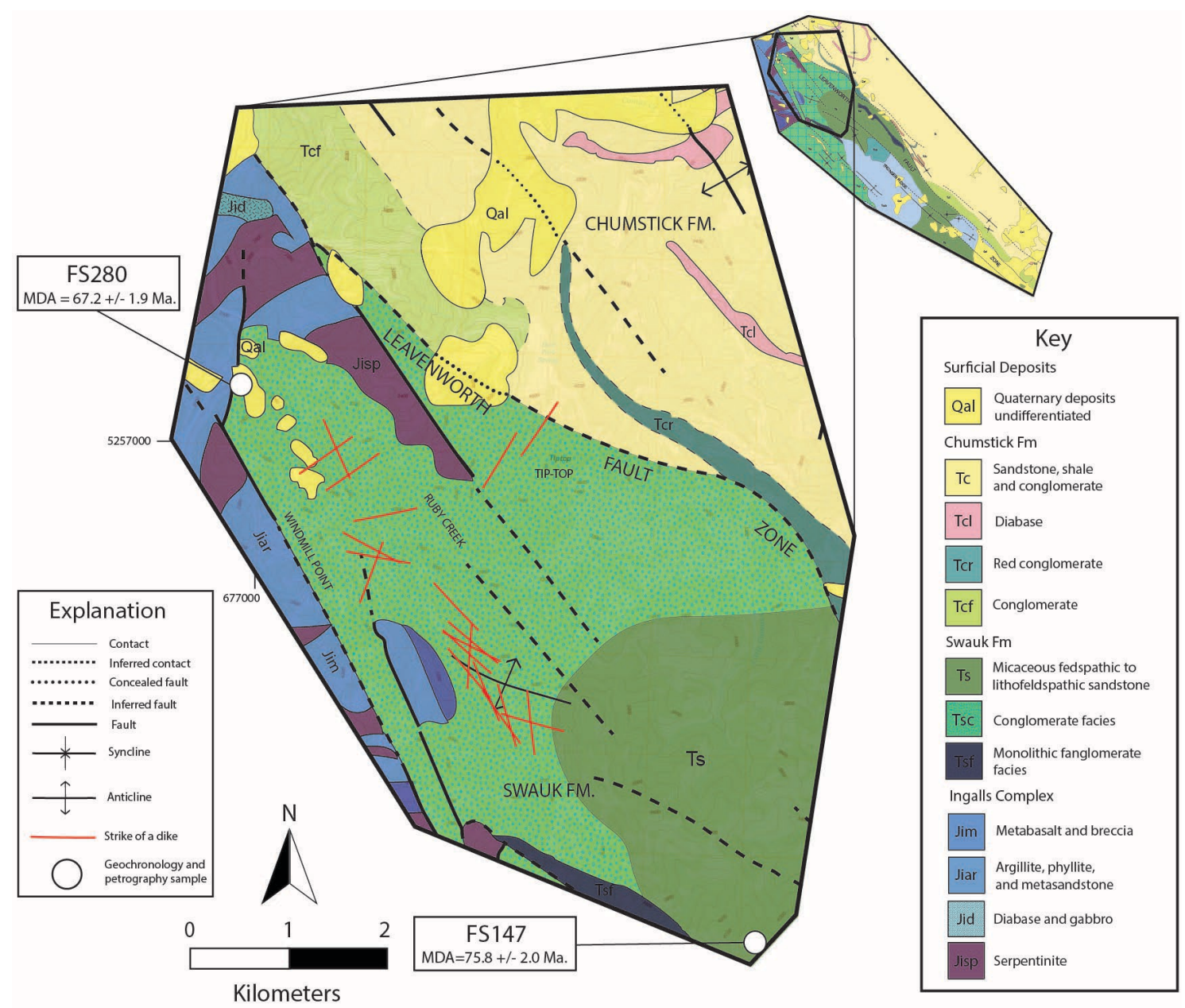

Figure 13. Geologic map emphasizing dikes in the Ruby Creek-Windmill Point and TipTop areas. Not all dikes are shown. 


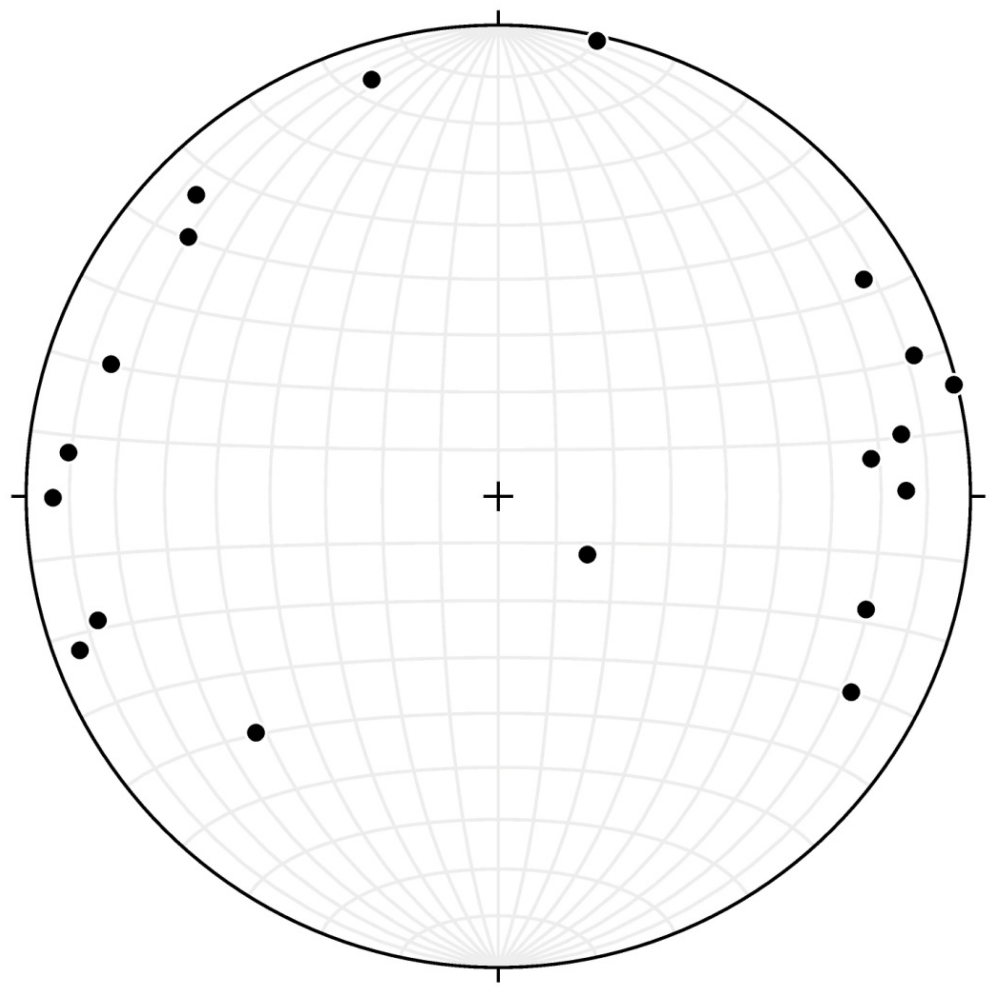

$\mathrm{n}=19$

Figure 14. Stereographic projection of poles to dikes intruding the Swauk Formation. Maximum of $179^{\circ}, 87^{\circ} \mathrm{SW}$. 
and averages $\sim 15 \mathrm{~m}$ (Fig. 15).

Tip-Top (Fig. 7) is located east and southeast of the Ruby Creek-Windmill Point area and lies within the $\sim 3-\mathrm{km}$-wide Leavenworth fault zone. Measurements were taken on both sides of the Leavenworth fault, as far as $0.5 \mathrm{~km}$ from the main fault strand. Poles to beds $(n=28)$ in the Swauk Formation (Fig. 16) show that most beds strike SE with a mean of $\sim 122^{\circ}$, and dips are to the SW, ranging from $\sim 0-90^{\circ}$, and have a mean of $\sim 66^{\circ}$. There is a reversal in dip orientation from SW to NE, as the main strand of the Leavenworth fault is approached. Bed orientations in the Chumstick Formation are discussed below.

Fault planes in the Tip-Top area $(n=22)$ strike mostly NW and NE, and average $342^{\circ}$ and $061^{\circ}$, respectively, and dip to the $\mathrm{NE}$ and $\mathrm{SE}$ with a range of $\sim 5-90^{\circ}$ and an average of $62^{\circ}$ and $71^{\circ}$, respectively (Fig. 17). Fault planes have a maximum of $150^{\circ}, 86^{\circ} \mathrm{SW}$. In addition, two out of 26 measured faults strike $>45^{\circ}$ clockwise $\left(019^{\circ}\right.$ and $\left.020^{\circ}\right)$ from the main strand of the Leavenworth fault, eight faults strike $44-31^{\circ}$ from the main fault, five of which strike clockwise $\left(333^{\circ}-003^{\circ}\right)$ and 3 of which strike counter-clockwise $\left(281^{\circ}\right.$ $287^{\circ}$ ) to the main fault. Sixteen faults strike $<30^{\circ}$ to the main fault, 8 of which strike counter-clockwise $\left(295^{\circ}-317^{\circ}\right)$ and 3 of which strike clockwise $\left(330^{\circ}-348^{\circ}\right)$ to the main fault.

Overall, rakes show significant scatter. Fault planes that strike NE have shallow to steep rakes, whereas fault planes that strike NW have mostly steep rakes. Shallow rakes show some clusters. All rakes average $51^{\circ}$, and $59 \%$ are $>45^{\circ}$.

Tronsen Ridge is located west of the main segment of the Leavenworth fault (Fig. 18). Two transects southwestward across this ridge from U.S. Highway 97 (Fig. 19), 


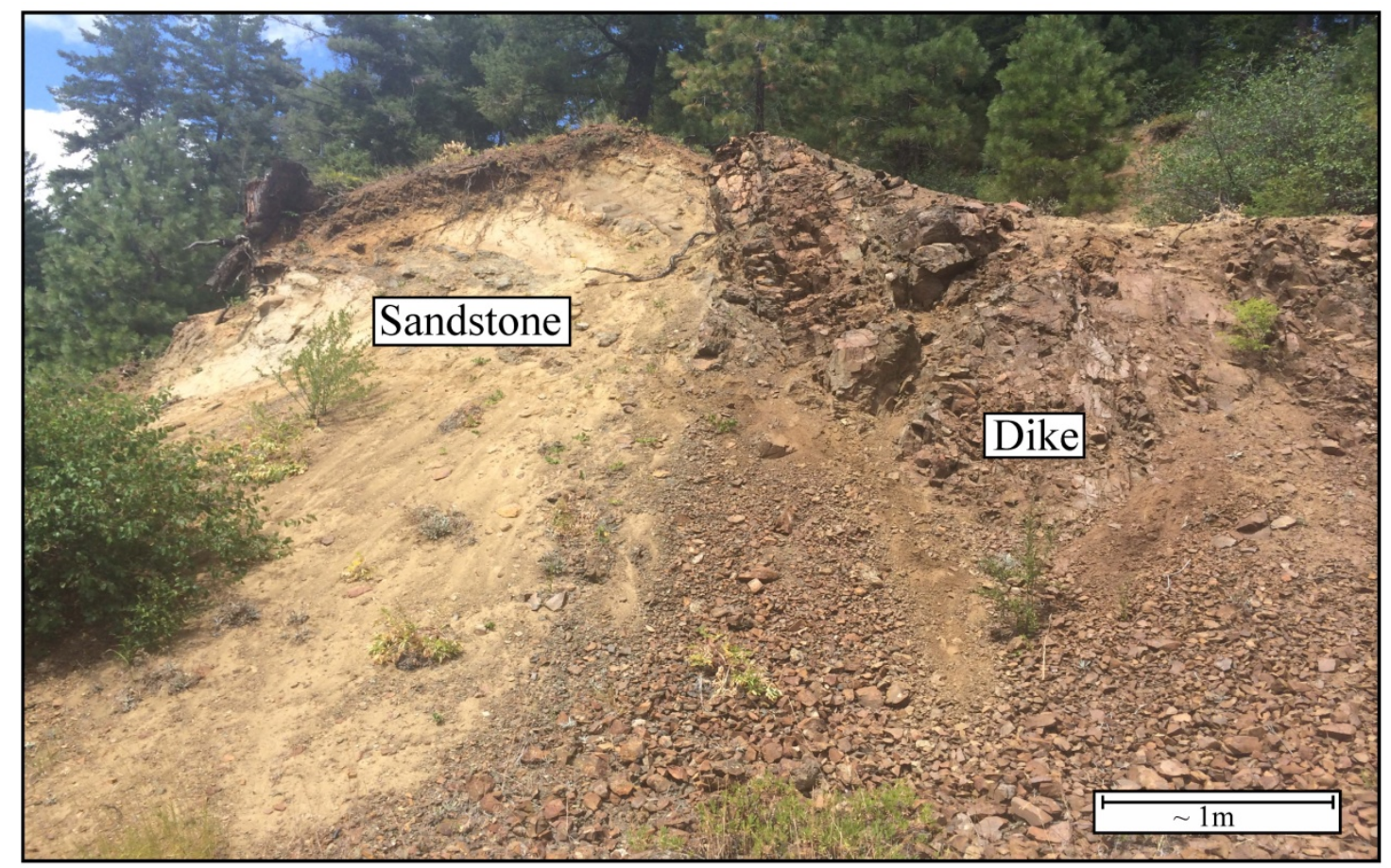

Figure 15. Outcrop exposing a contact of a Teanaway dike and Swauk sandstone in the Ruby Creek-Windmill Point area. 


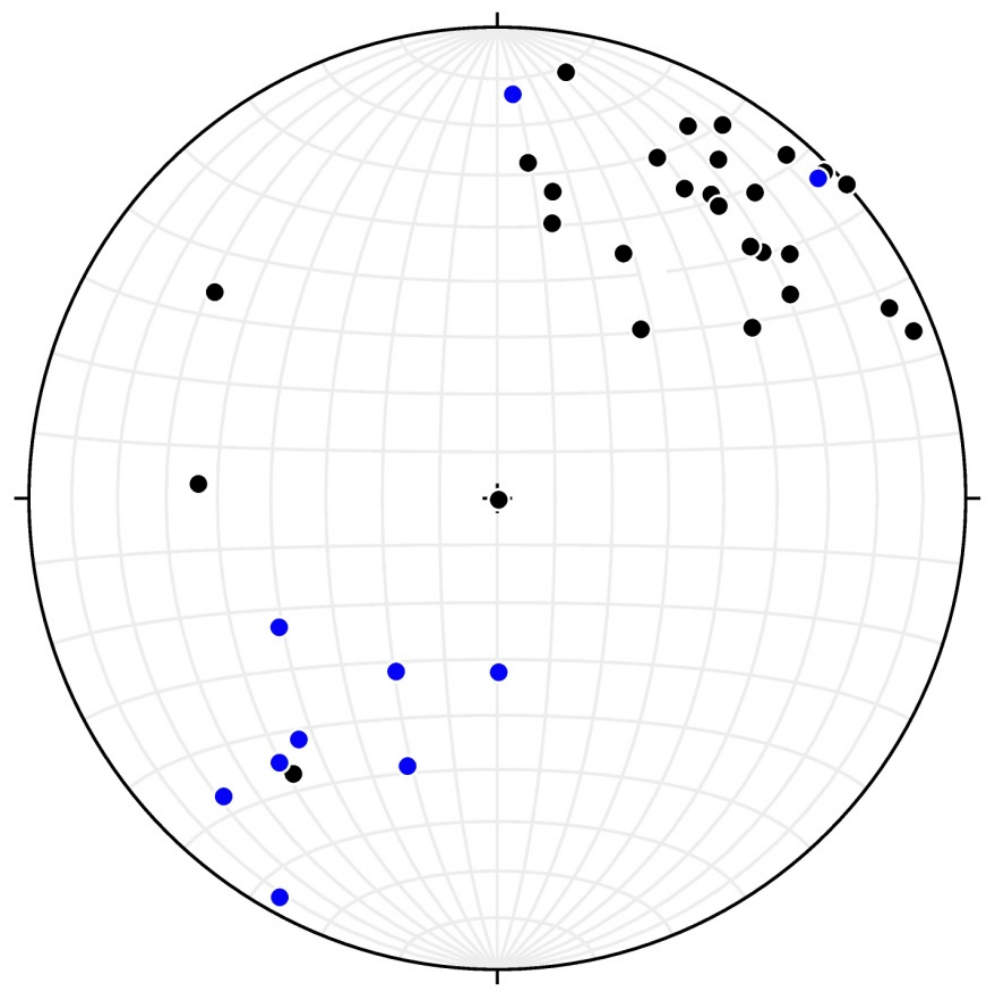

Swauk $n=28$

Chumstick $n=10$

Figure 16. Stereographic projection of poles to beds of the Swauk Formation (black) and Chumstick Formation (blue) in the Tip-Top area. The maximum for the Swauk beds is $127^{\circ}, 70^{\circ} \mathrm{SW}$, and the maximum for the Chumstick beds is $304^{\circ}, 61^{\circ} \mathrm{NE}$. 


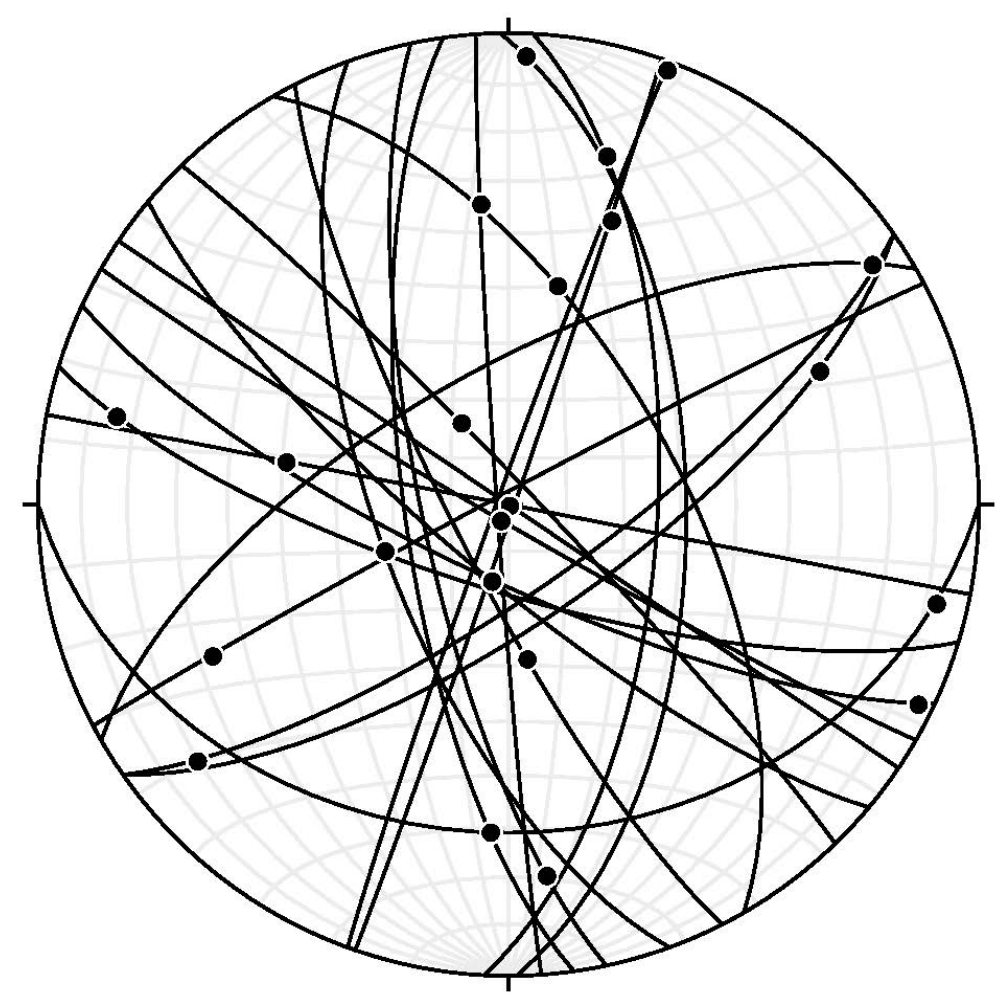

$\mathrm{n}=22$

Figure 17: Stereographic projection of faults and rakes (dots) in the Tip-Top area. Maximum of faults is $150^{\circ}, 86^{\circ} \mathrm{SW}$. 

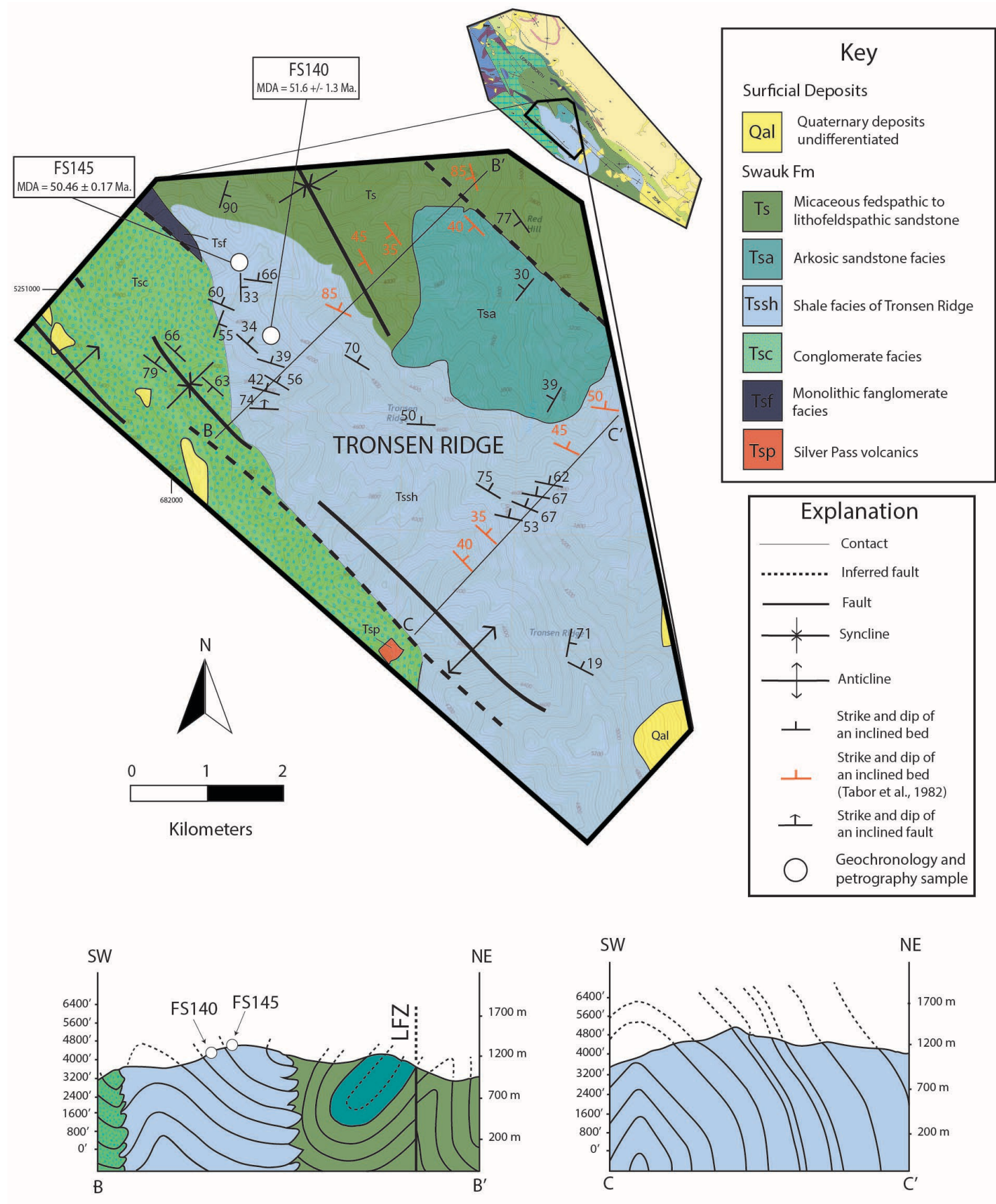

No vertical exaggeration

Figure 18. Geologic map showing orientations of beds $(n=24)$, and cross sections B-B' and $\mathrm{C}^{-} \mathrm{C}^{\prime}$ in the Tronsen Ridge area. Not all data are shown. Thin lines in cross sections indicate traces of bedding. 


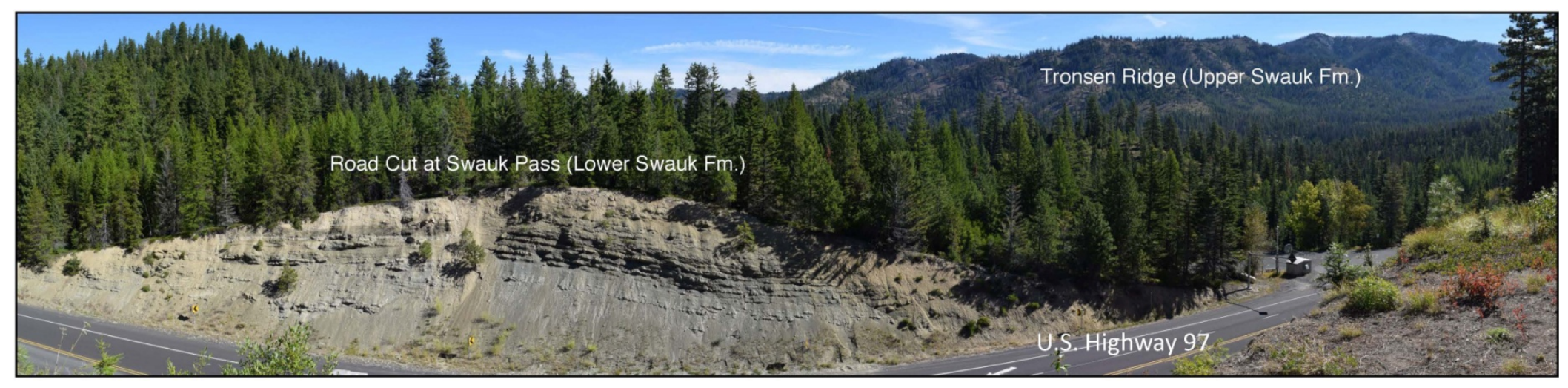

Figure 19. Panoramic view looking east from U.S. Highway 97 of the lower and upper Tronsen Ridge members of the Swauk Formation. Modified from Eddy et al. (2017). 
cross the $\sim 5 \mathrm{~km}$ width of the fault zone. Here, the Leavenworth fault strikes $\sim 330^{\circ}$. Beds $(n=27)$ in the northern transect of the Tronsen Ridge transect strike NW with a mean of $\sim 300^{\circ}$, and dips range from $\sim 33-79^{\circ}$ to the NE, and have a mean of $\sim 53^{\circ}$ (Fig. 18). As a NW-trending syncline and a small NW-striking strand of the Leavenworth fault are approached, bed dips rotate from NE-dipping to SW-dipping. In the southern transect, beds strike WNW with a mean of $\sim 300^{\circ}$, and dips range from $\sim 67-39^{\circ}$ to the NE, with a mean of $\sim 56^{\circ}$. Bed strikes overall on Tronsen Ridge have a maximum of $295^{\circ}, 62^{\circ} \mathrm{NE}$. The poles to beds define a girdle, and a fold axis plunging $008^{\circ}$ towards $300^{\circ}$ (Fig. 20). The significant scatter of poles indicates non-cylindrical folding (Fig. 20). Four fold axial traces mapped on Tronsen Ridge average $321^{\circ}$. Most fold interlimb angles are $\sim 85^{\circ}$, and line-length balancing yields $\sim 1.7-2.2 \mathrm{~km}$ of cumulative shortening (Fig. 18).

The southernmost study area in the Swauk Formation was along Mission Ridge (Fig. 21). Here, the fault zone is $\sim 2 \mathrm{~km}$ wide, and the Leavenworth fault strikes $\sim 310^{\circ}$. In the Swauk Formation, measurements were taken $<1.5 \mathrm{~km}$ west of the Leavenworth fault. Bed strikes $(n=33)$ are oblique to the strike of the Leavenworth fault zone, averaging $\sim 291^{\circ}$, and have a predominant SW-SSW dip ranging from $\sim 20-84^{\circ}$, and a mean of $\sim 54^{\circ}$. Beds have a maximum of $289^{\circ}, 59^{\circ} \mathrm{SW}$. Three folds of $\sim 200 \mathrm{~m}-1.3 \mathrm{~km}$ wavelength defined by bedding reversals have trends averaging $286^{\circ}$. Poles to beds in the Mission Ridge area in the Swauk Formation plot as a poorly defined girdle indicating a fold axis plunging $003^{\circ}$ towards $287^{\circ}$ (Fig. 22). The significant scatter indicates non-cylindrical folding. Bed orientations in the Chumstick Formation are discussed below.

For the entire study area, poles to beds $(n=207)$ in the Swauk Formation indicate a 


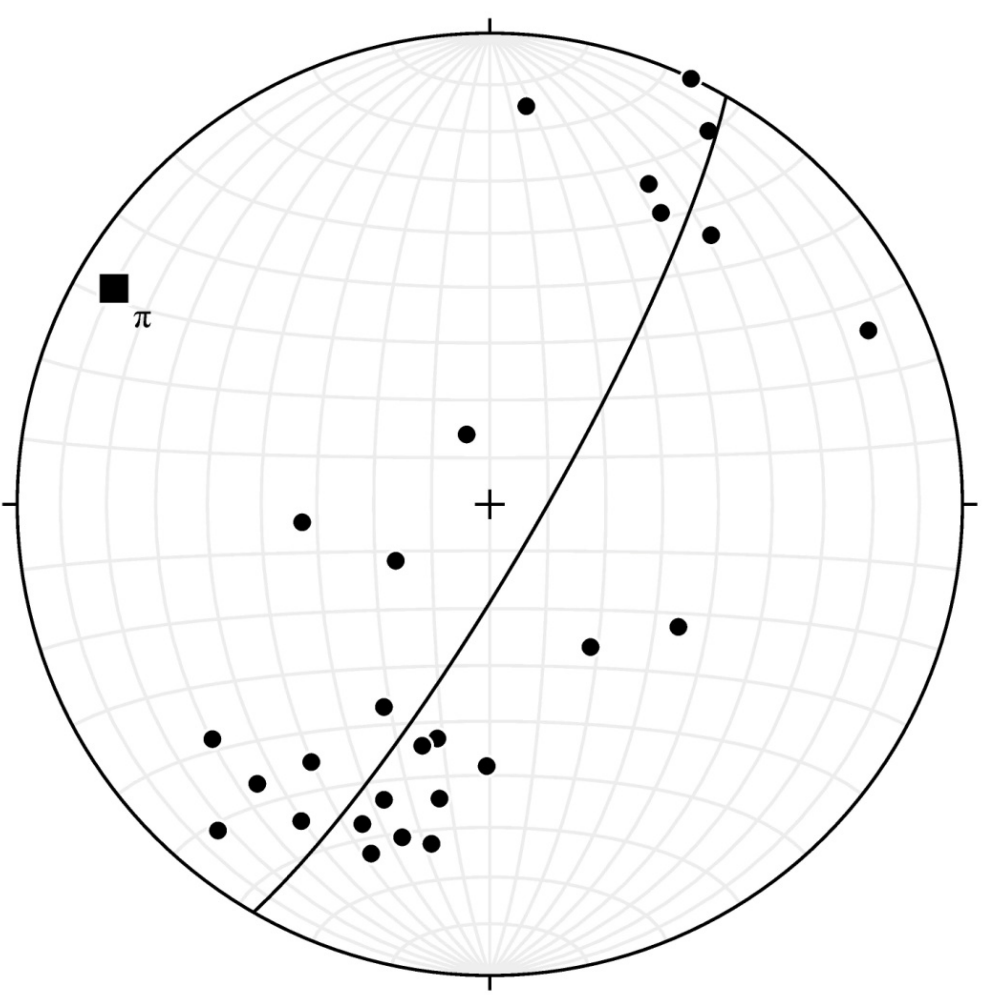

$\mathrm{n}=27$

Figure 20. Stereographic projection of poles to beds on Tronsen Ridge. $\Pi=08^{\circ}, 300^{\circ}$. Maximum of $295^{\circ}, 62^{\circ} \mathrm{NE}$. 

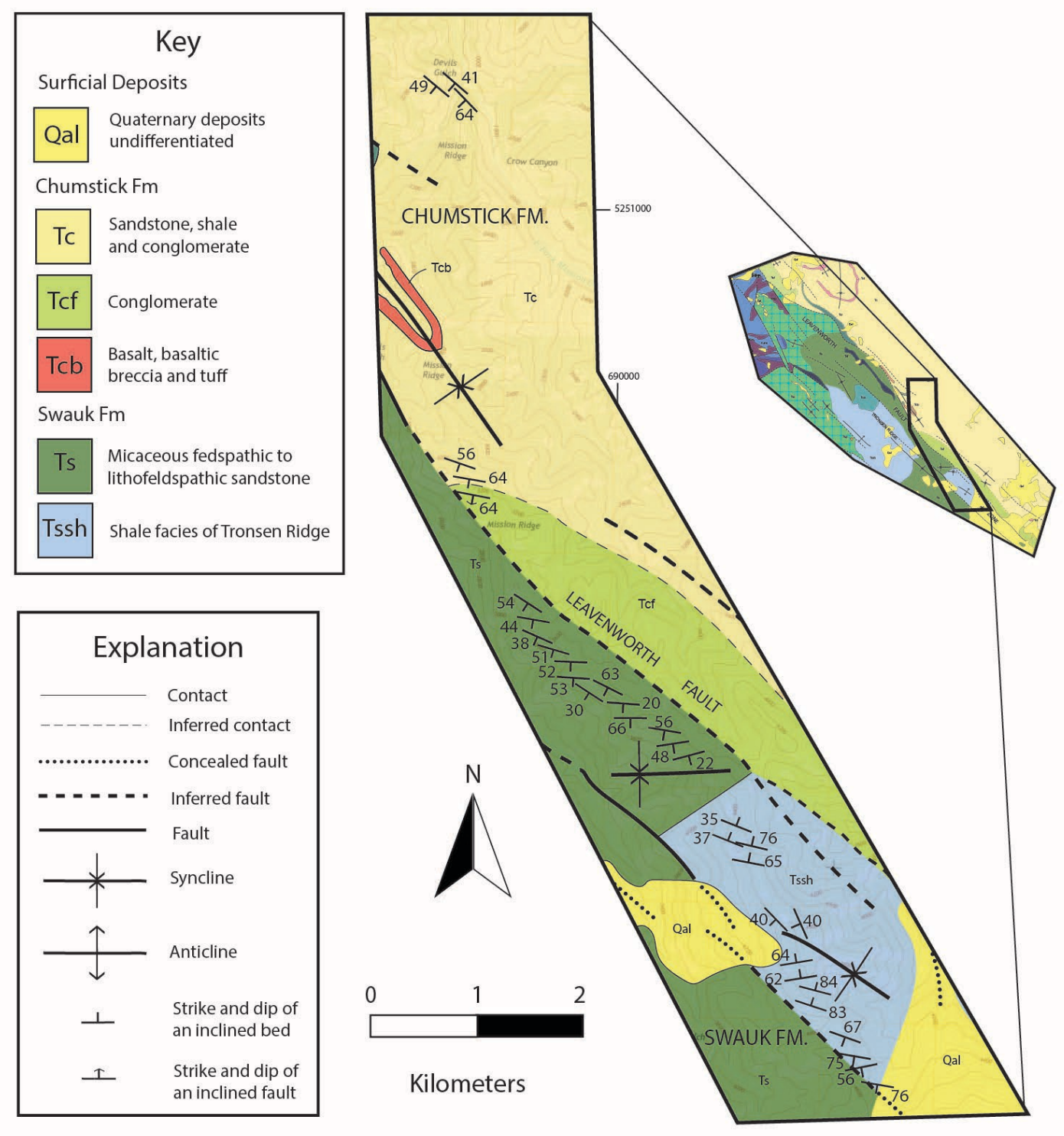

Figure 21. Geologic map emphasizing orientations of beds $(n=27)$ on Mission Ridge. Not all data are shown. 


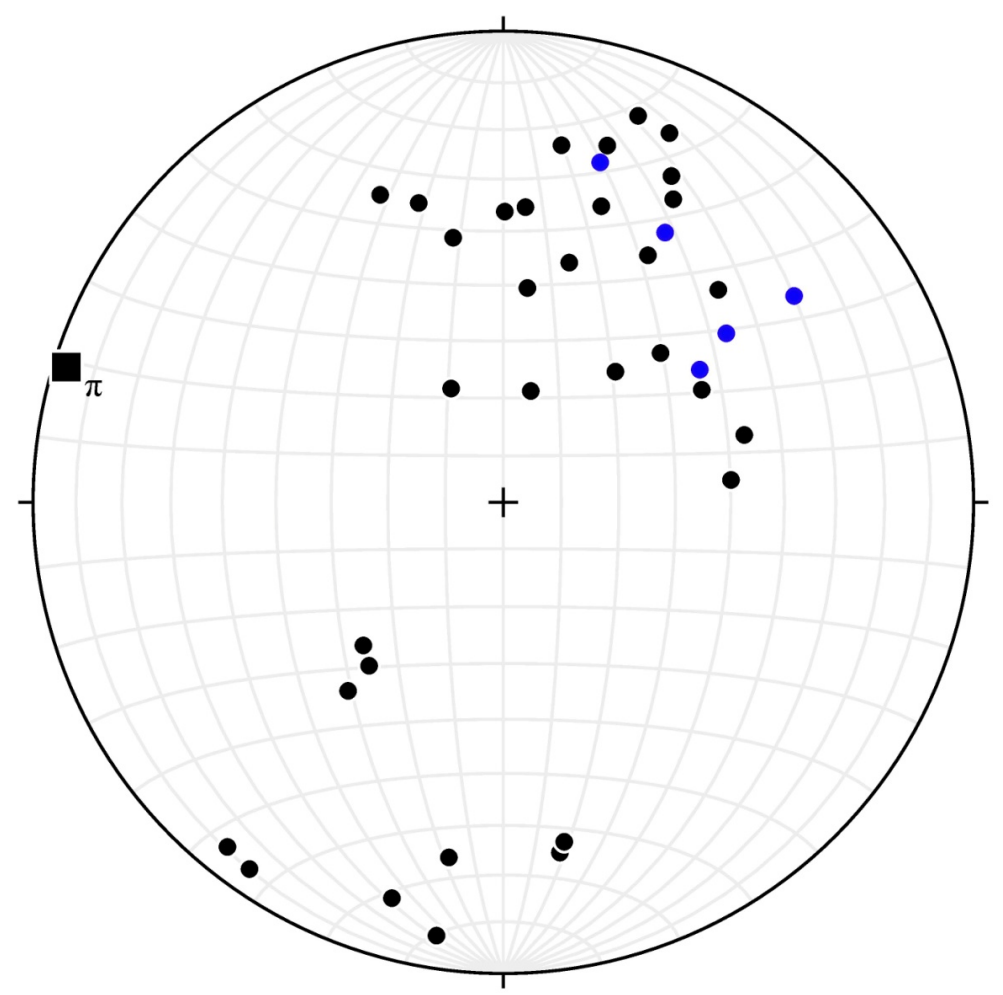

Swauk $n=33$

Chumstick $n=5$

Figure 22. Stereographic projection of poles to beds in the Swauk Formation (black) and Chumstick Formation (blue) on Mission Ridge. Fold axis $(\pi)$ and bed maximum for the Swauk Formation are $03^{\circ}, 287^{\circ}$ and $289^{\circ}, 59^{\circ} \mathrm{SW}$, respectively, and the maximum for the Chumstick Formation is $131^{\circ}, 54 \mathrm{SW}^{\circ}$. 
maximum of $119^{\circ}, 61^{\circ} \mathrm{SSW}$. Dips of Swauk beds average $55^{\circ}$. They define a girdle and a fold axis plunging $4^{\circ}$ toward $297^{\circ}$ (Fig. 23). There is a significant scatter of attitudes indicating non-cylindrical folding. Folds mapped in the Swauk Formation $(\mathrm{n}=15)$ of $\sim 0.5$ $2.5 \mathrm{~km}$ wavelength trend NW to $\mathrm{WNW}$, and range from $\sim 270-340^{\circ}$. Most folds trend $\sim 290-330^{\circ}$, and the average is $\sim 298^{\circ}$, counter-clockwise from the main strand of the Leavenworth fault.

Poles $(\mathrm{n}=65)$ to all fault planes in Swauk rocks have scattered strikes, with concentrations striking NE and NW, and dipping to the SE and NE. The maximum is $359^{\circ}, 84^{\circ} \mathrm{E}$ (Fig. 24).

\section{Chumstick Formation}

From north to south, mapping in the Chumstick Formation was conducted primarily in the Tip-Top area (Fig. 7), along Mission Ridge (Fig. 21), and in the Beehive Reservoir area (Fig. 25). These areas extend as far as $\sim 3 \mathrm{~km}$ from the main trace of the Leavenworth fault.

In the Tip-Top area of the Chumstick Formation (Fig. 7), beds ( $\mathrm{n}=10)$ strike NW with a mean of $\sim 298^{\circ}$, have a predominant NE dip ranging from $30-86^{\circ}$, and have a mean dip of $\sim 60^{\circ}$ NE. Poles to beds indicate a maximum of $304^{\circ}, 61^{\circ} \mathrm{NE}$ (Fig. 16). Fault strikes in the Tip-Top area are relatively consistent (Figs. 7 and 10); strikes are SSW with a mean of $\sim 184^{\circ}$, and dips are steep to the SE and NW, with a mean of $\sim 76^{\circ}$ (Fig. 26). In addition, two out of the nine measured faults strike $>45^{\circ}$ counter-clockwise $\left(052^{\circ}\right.$ and $065^{\circ}$ ) from the main strand of the Leavenworth fault; one fault strikes $40^{\circ}\left(280^{\circ}\right)$ to the fault, and six strike $<30^{\circ}$ to the fault, five of which strike clockwise $\left(322-350^{\circ}\right)$, and one 


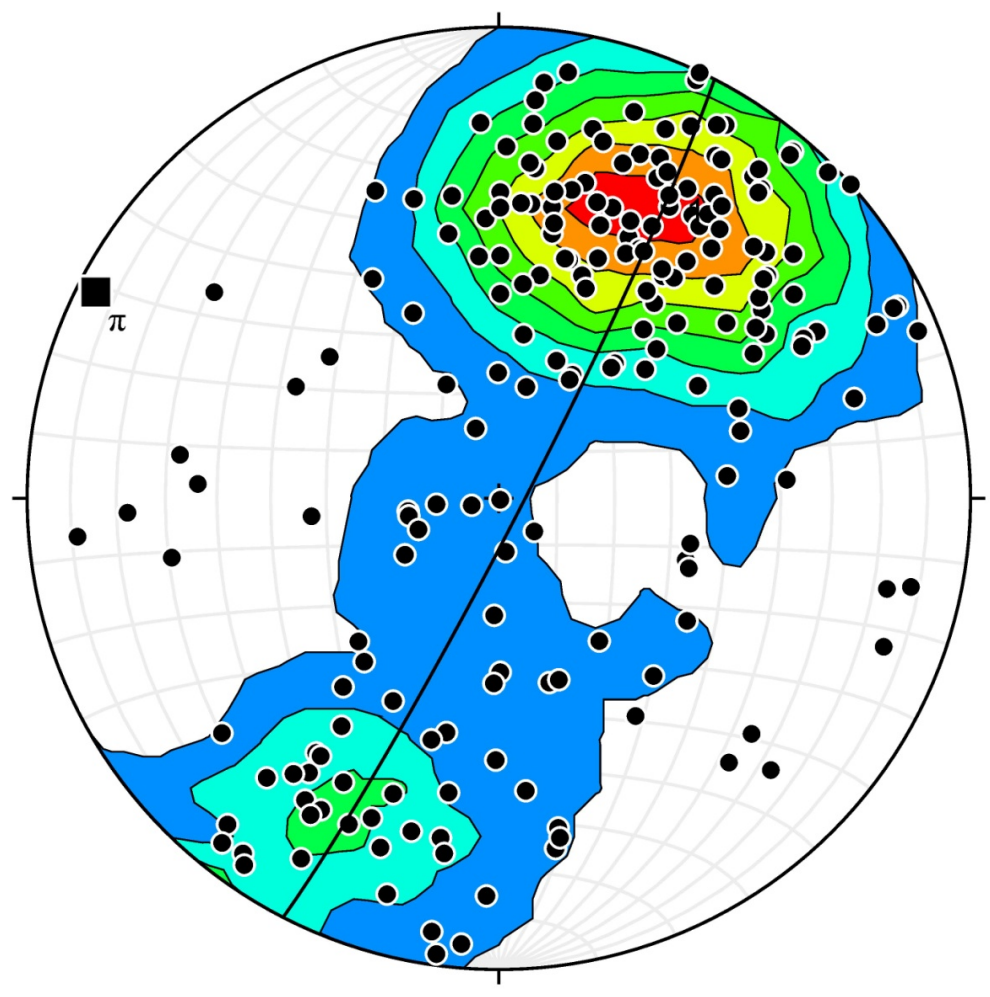

$\mathrm{n}=207$

Figure 23. Stereographic projection of all poles to beds in the Swauk Formation. Kamb (1959) method, contour interval of $2 \sigma . \Pi=4^{\circ}, 297^{\circ}$. Maximum of $119^{\circ}, 61^{\circ} \mathrm{SSW}$. 


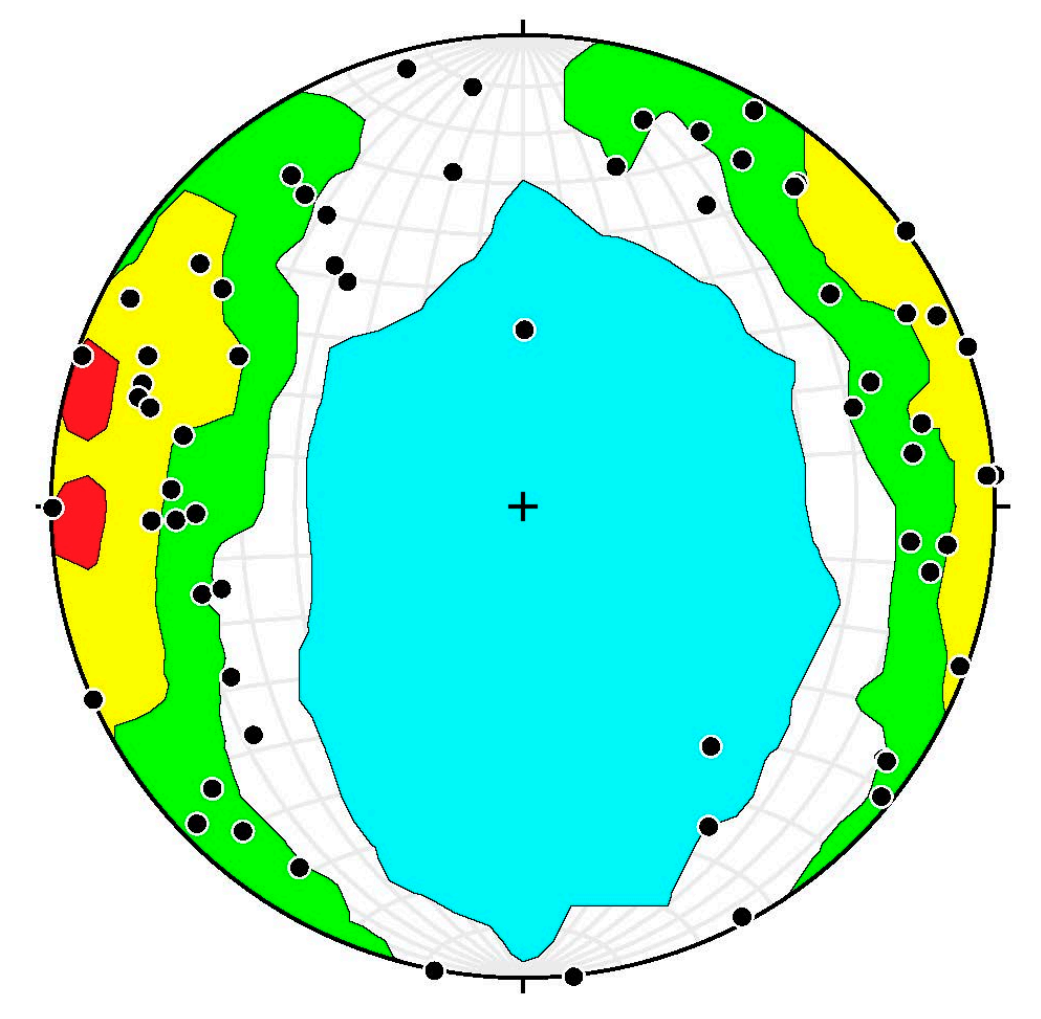

$\mathrm{n}=65$

Figure 24. Stereographic projection of all poles to fault planes in the Swauk Formation. Kamb (1959) method, contour interval of $2 \sigma$. Maximum of $359^{\circ}, 84^{\circ} \mathrm{E}$. 


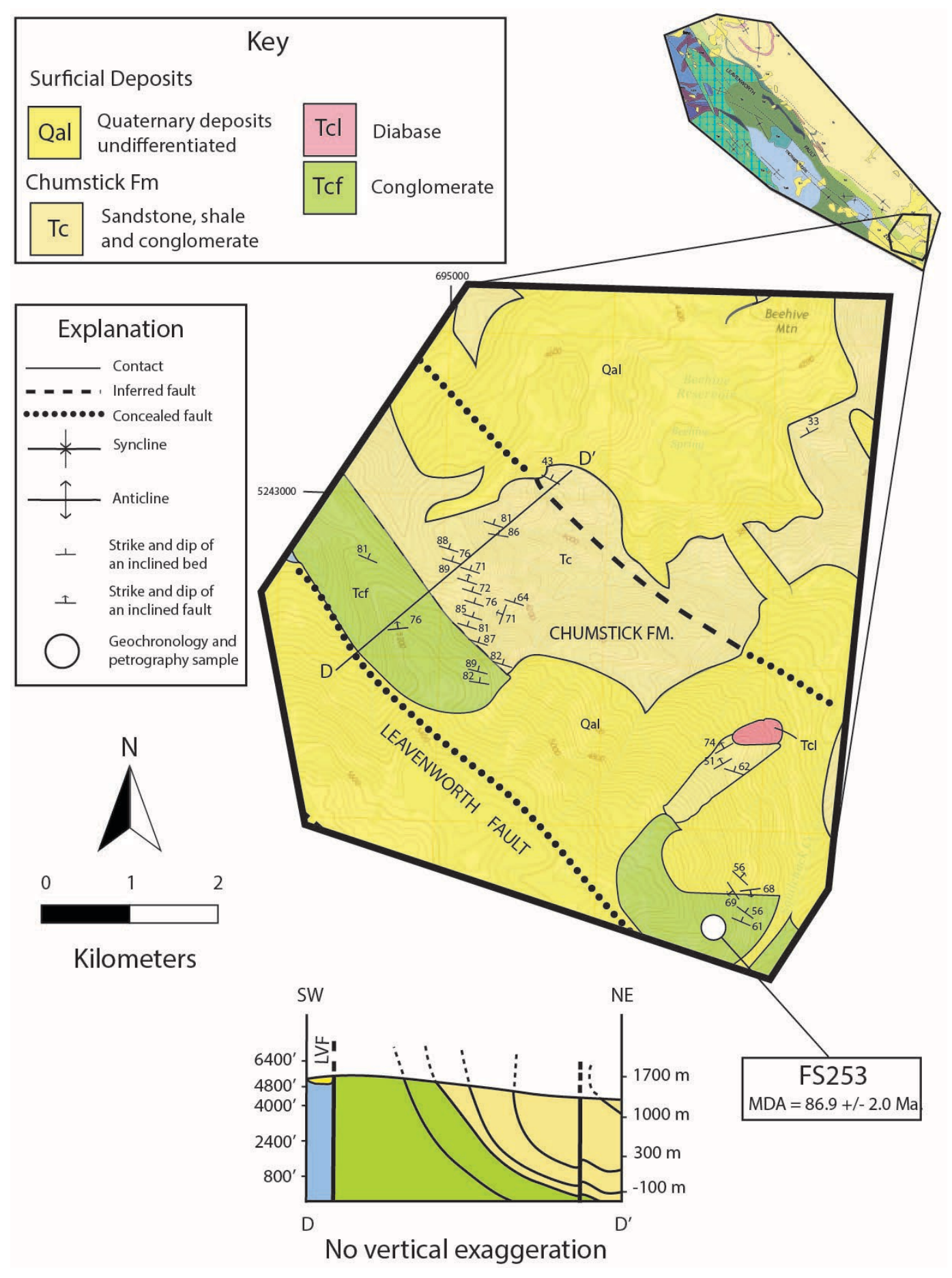

Figure 25. Geologic map of orientations of beds $(n=19)$ and faults $(n=8)$, and cross section D-D' in the Beehive Reservoir area. Not all data are shown. Thin lines in cross sections indicate traces of bedding. 


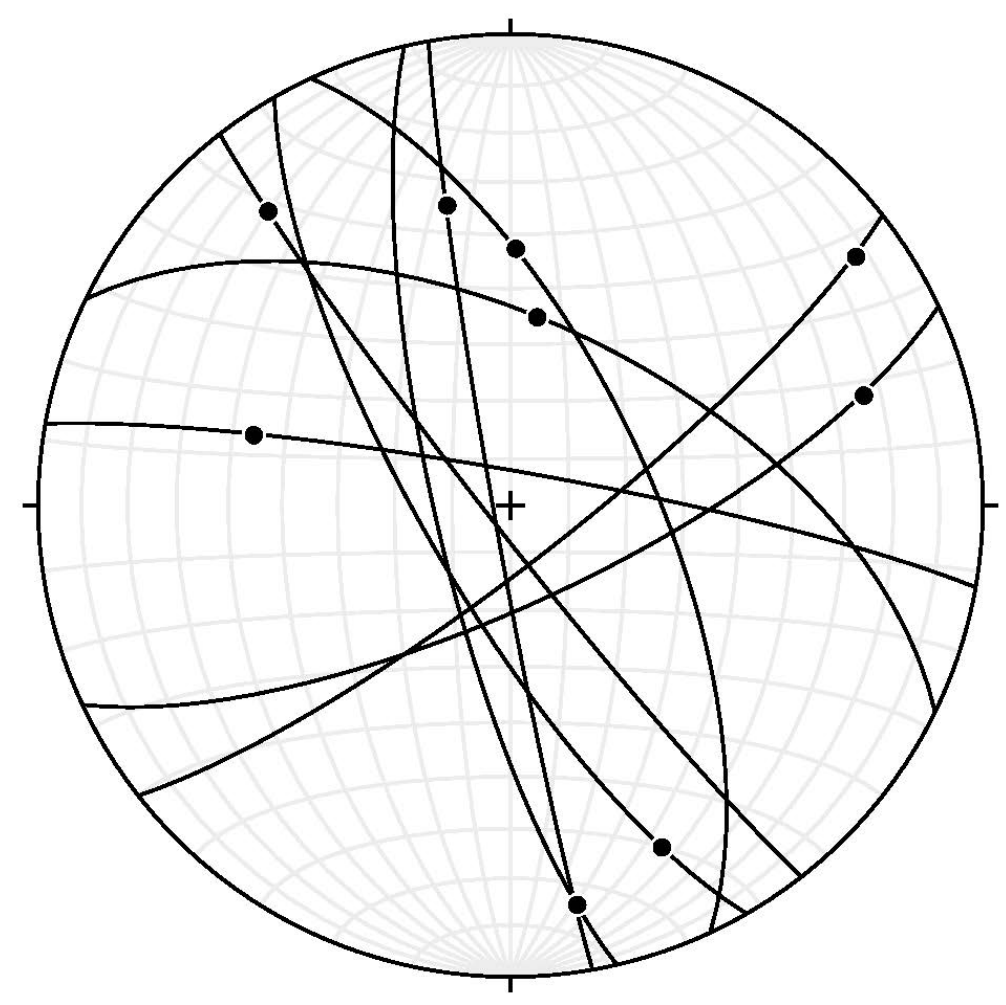

$\mathrm{n}=9$

Figure 26. Stereographic projection of faults and rakes (dots) in the Tip-Top area of the Chumstick Formation. 
of which strikes counter-clockwise $\left(296^{\circ}\right)$ to the Leavenworth fault. Fault strikes average $264^{\circ}$. Rakes are scattered, vary from $\sim 11-80^{\circ}$, and average $50^{\circ}$. Fifty-five per cent of rakes are $>45^{\circ}$ (Fig. 26).

Mission Ridge extends as far as $\sim 3 \mathrm{~km}$ east of the main segment of the Leavenworth fault (Fig. 21). The few beds ( $\mathrm{n}=5$ ) cluster and have a mean strike of $\sim 131^{\circ}$, a SW dip that ranges from $\sim 41-64^{\circ}$, and a mean of $\sim 55^{\circ}$ (Fig. 22). Broad folding is indicated by bedding rotation from NW strikes $\sim 2 \mathrm{~km}$ from the fault to WNW strikes near the fault (Fig. 21). In addition, Tabor et al. (1982) mapped an anticline and two synclines in the Chumstick Formation on Mission Ridge (Fig. 21).

The Beehive Reservoir study area (Fig. 25) extends as far as $\sim 2 \mathrm{~km}$ east of the main fault. Here, the Leavenworth fault zone is $\sim 1.5 \mathrm{~km}$ wide, and strikes $\sim 315^{\circ}$. Beds ( $\mathrm{n}=35$ ) strike NW with a mean of $\sim 301^{\circ}$; dips are to the NE, range from $33-90^{\circ}$, and have a mean of $\sim 75^{\circ}$. Poles to beds $(n=35)$ indicate a maximum of $302^{\circ}, 76^{\circ}$ NE (Fig. 27).

In the Beehive Reservoir area, the 16 measured faults have $>3 \mathrm{~m}$ displacement. Ten of these faults strike $>45^{\circ}$ from the main strand of the Leavenworth fault, eight of which strike clockwise $\left(020-031^{\circ}\right)$, and two of which strike counter-clockwise $\left(085^{\circ}\right.$ and $\left.270^{\circ}\right)$. Six out of the 16 measured faults strike $<30^{\circ}$ from the Leavenworth fault, five of which strike counter-clockwise (300-311 $)$ to the fault, and one of which strikes clockwise $\left(326^{\circ}\right)$ to the fault. Fault planes with rakes strike NW and NE with a mean of $\sim 001^{\circ}$, dip $\mathrm{NE}$ and NW with a mean of $71^{\circ}$, and have a maximum of $271^{\circ}, 77^{\circ} \mathrm{N}$. Rakes are primarily moderate to steep and range from $3-89^{\circ}$, with an average of $56^{\circ}$ (Fig. 28).

Overall, beds $(\mathrm{n}=50)$ in the study areas in the Chumstick Formation strike NW 


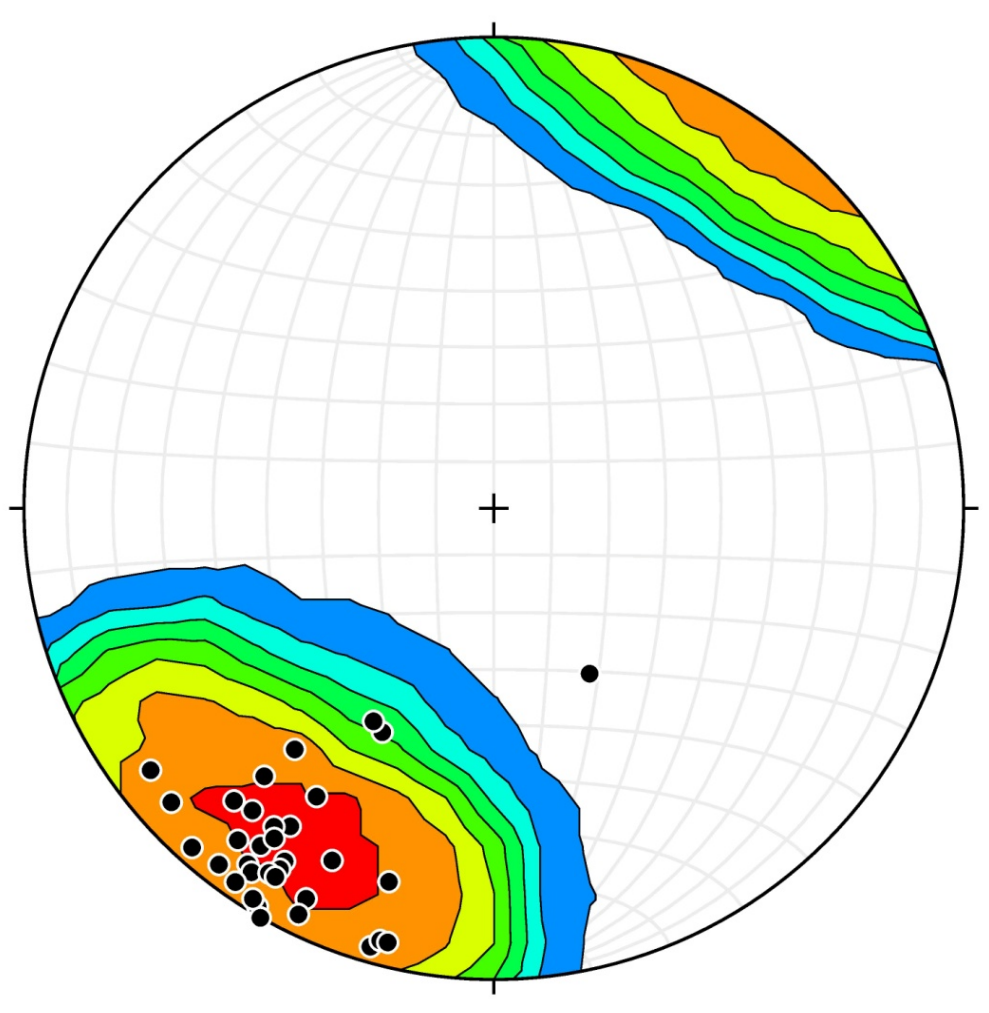

$\mathrm{n}=35$

Figure 27. Stereographic projection of poles to beds in the Beehive Reservoir area. Kamb (1959) method, contour interval of $2 \sigma$. 


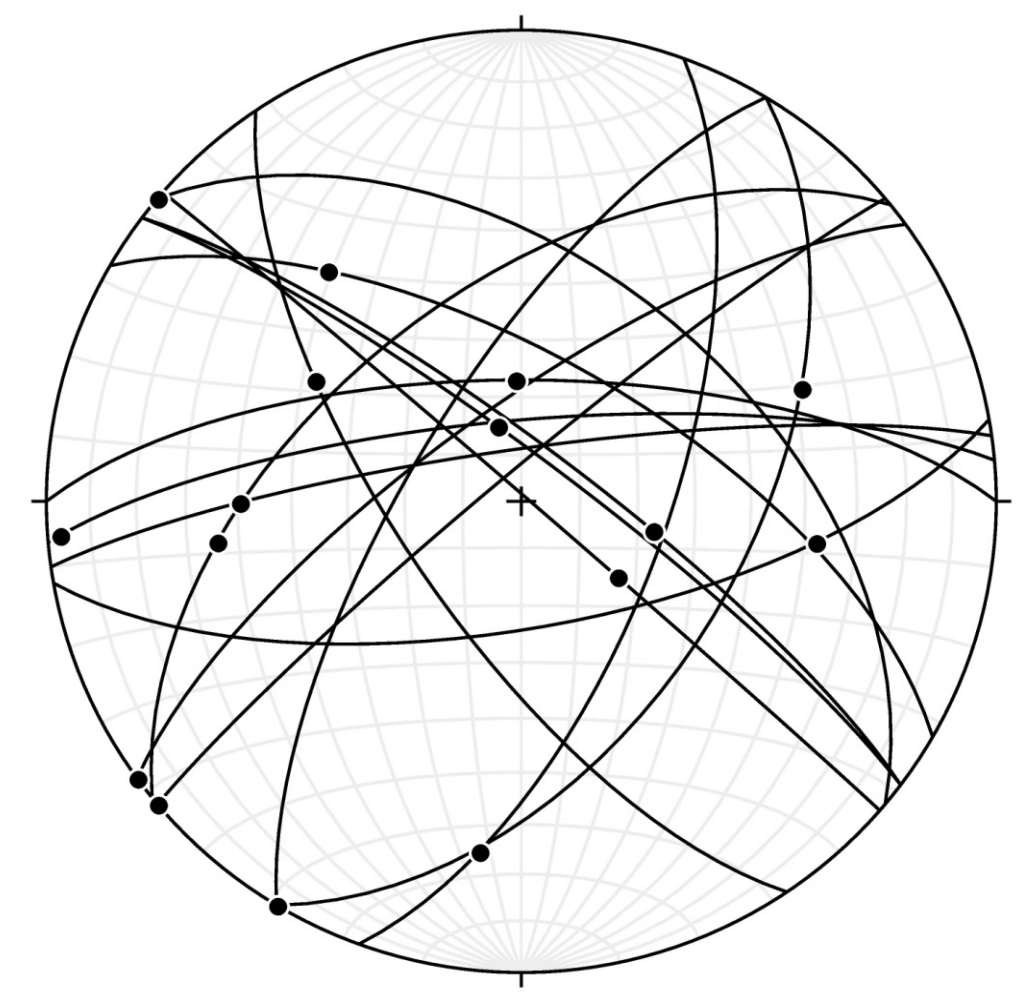

$\mathrm{n}=16$

Figure 28. Stereographic projection of faults and rakes (dots) in the Beehive Reservoir area. Maximum $=271^{\circ}, 77^{\circ} \mathrm{NNE}$. 
(averaging $\sim 306^{\circ}$ ) and dip mostly to the $\mathrm{NE}$ (mean of $66^{\circ}$ ). On a stereographic projection, poles to beds (Fig. 29) define a girdle with a maximum $\left(304^{\circ}, 80^{\circ} \mathrm{NE}\right)$, and indicate a fold axis plunging $13^{\circ}$ towards $306^{\circ}$. Six folds of $\sim 200 \mathrm{~m}-1.3 \mathrm{~km}$ wavelength trend NW $\left(\sim 270^{\circ}-360^{\circ}\right)$, and average $\sim 312^{\circ}$.

\section{PETROGRAPHY}

\section{Swauk Formation}

The goal of the petrographic study is to analyze the constituents of each clastic sample and to gain a better understanding of the provenance of the grains and rock fragments. A total of 8 sandstones from the Swauk Formation were analyzed for petrographic and point counting analysis, and results were plotted on a QFL ternary diagram (Dickinson and Suczek, 1979, Dickinson et al., 1983). The samples are described in stratigraphic order, and they are from Ruby Creek-Windmill Point (FS280, FS151, FS149) and Tronsen Ridge and vicinity (FS140, FS145, FS147, FS224, FS224A) (Fig. 30).

All Swauk sandstones consist dominantly of quartz, plagioclase (commonly fractured), lithics and micas. They are lithic arkose, subarkose, and feldspathic litharenite, plotting mostly in the transitional continental field, the recycled orogenic field, the dissected arc provenance field, and the mixed field on a QFL ternary diagram (Fig. 31). Secondary calcite and chlorite are abundant in some samples. Mineral modes for the set of samples before normalizing the data plotted in the QFL ternary diagrams (Appendix B) are as follows: quartz ranges from $\sim 36-68 \%$ and averages $\sim 49 \%$; feldspars range from $\sim 14-32 \%$ and average $\sim 23 \%$; and biotite ranges from $\sim 3-8 \%$ and averages $\sim 5 \%$. 


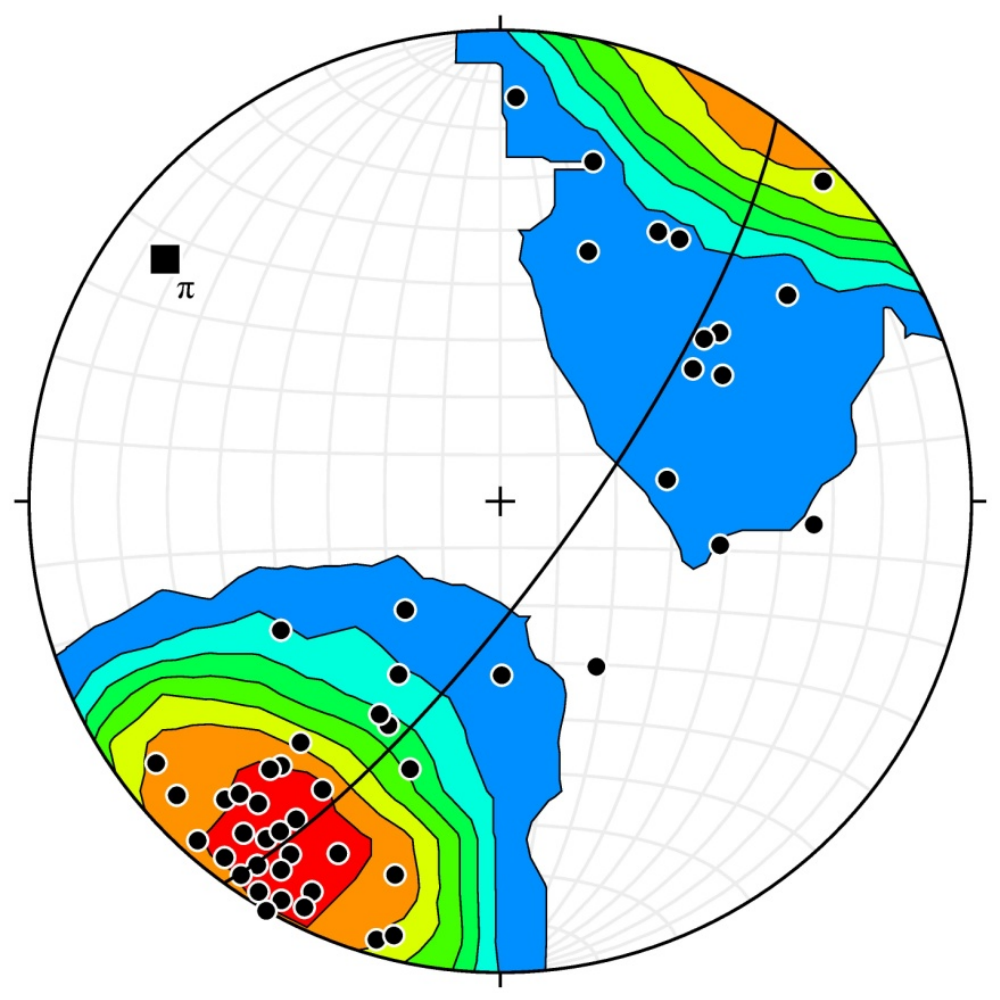

$\mathrm{n}=50$

Figure 29. Stereographic projection of all poles to beds in the Chumstick Formation. Kamb (1959) method, contour interval of $2 \sigma . \Pi=306^{\circ}, 13^{\circ}$. Maximum of $304^{\circ}, 80^{\circ} \mathrm{NE}$. 


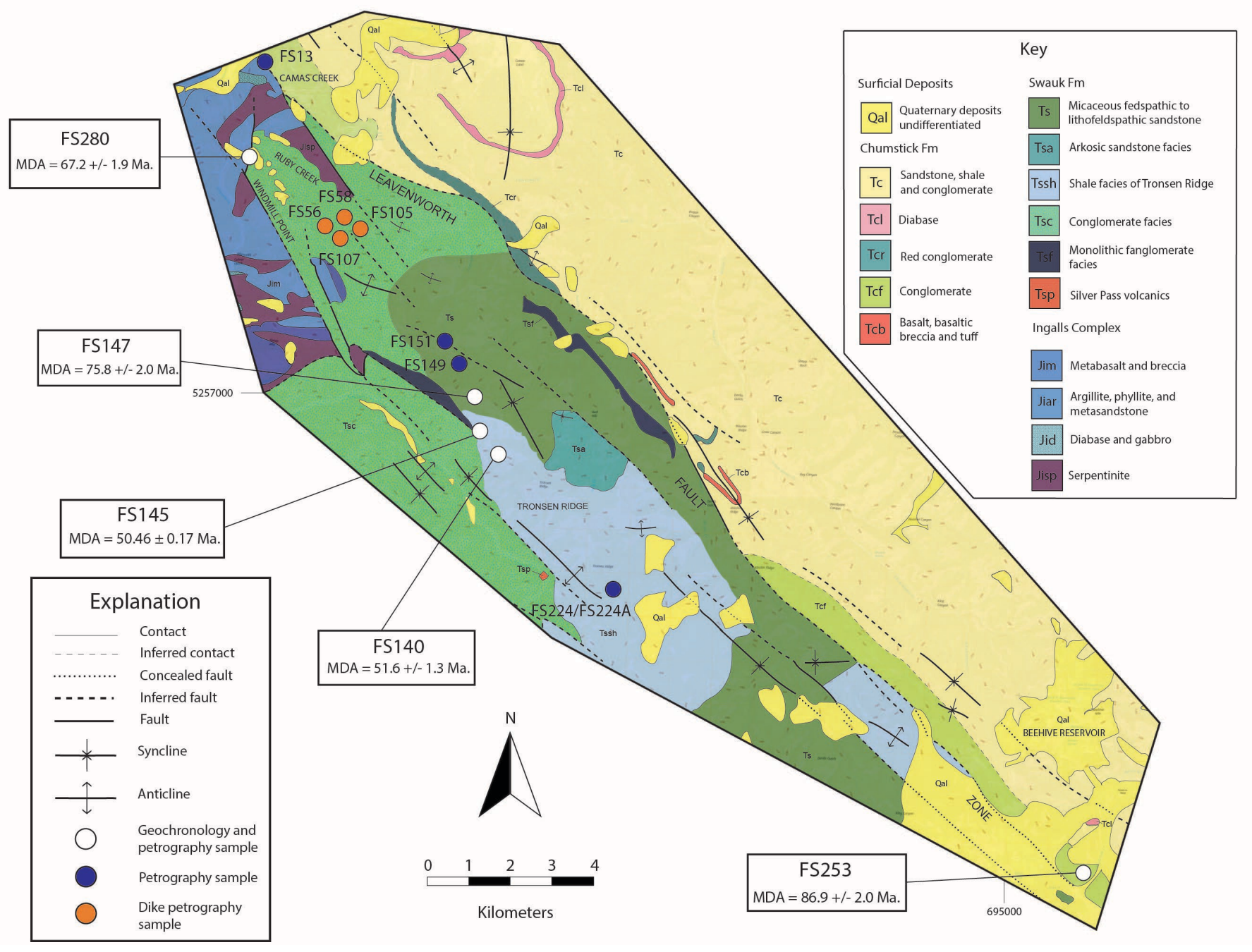

Figure 30. Map of the field area showing the location of dated samples and samples petrographically analyzed. Maximum depositional ages (MDA) are also listed. See Appendix A for list of UTM locations of dated samples. 

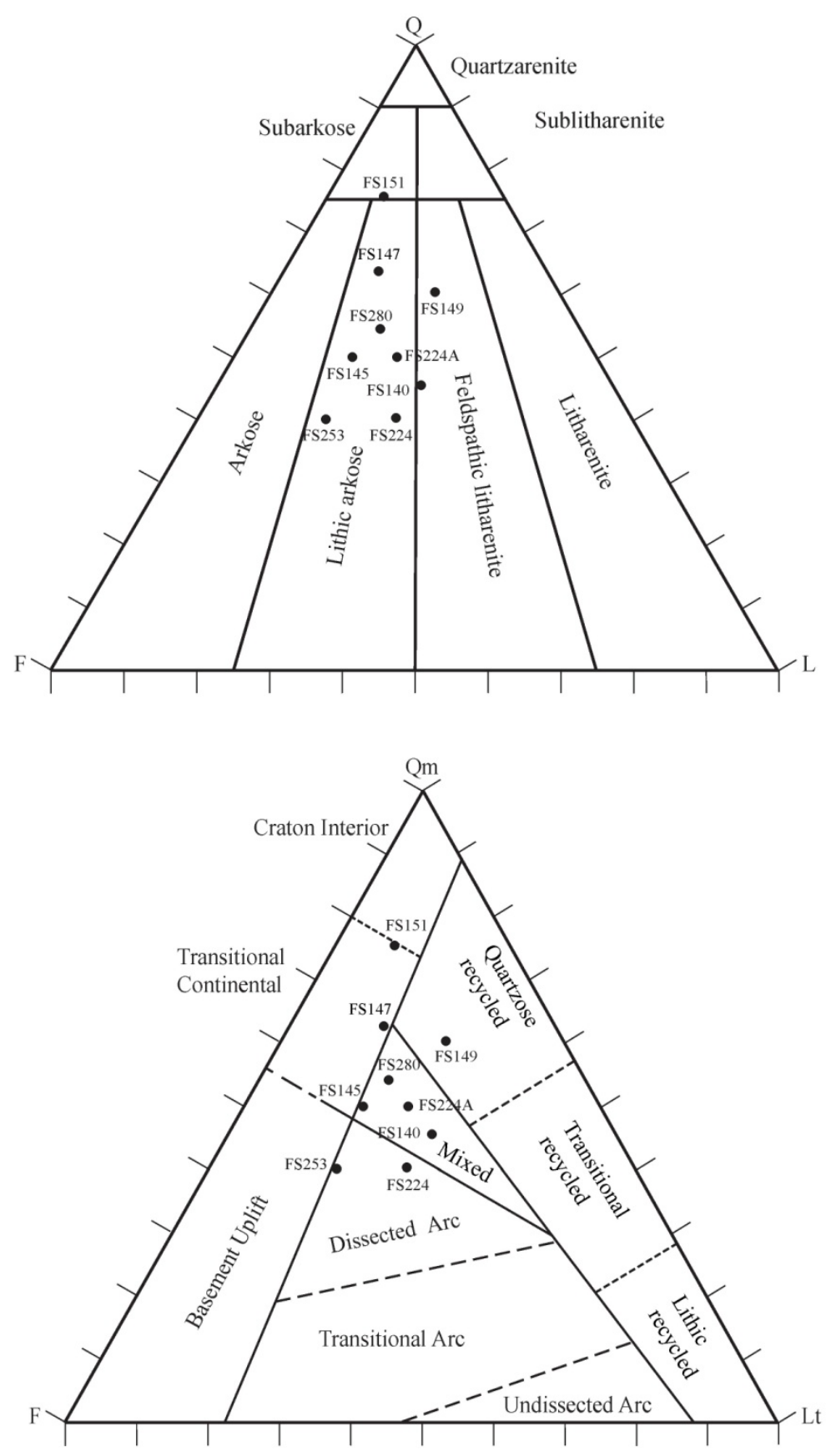

Figure 31. Ternary plots for Swauk Formation sandstones and FS253 of the Chumstick Formation. Samples plot primarily as lithic arkoses and feldspathic litharenites and in the transitional continental, dissected arc, mixed, and quartzoze recycled provenance fields (Dickinson et al., 1983). Q-F-Lt values were normalized to equal 100\%. See Appendix B for detailed point counting data. 
Miscellaneous and unidentified components include muscovite, oxides, and cement. Chert, unidentified metamorphic clasts, and/or volcanic rock fragments are common in most samples (Appendix B) and are described in more detail below.

Sample FS280 (MDA $=67.2 \pm 1.9$ Ma.) was collected at the northwestern end of the Ruby Creek-Windmill Point transect (Fig. 30). The sandstone is clast supported and mostly coarse grained. On a QFL ternary diagram, this sample is a lithic arkose (Fig. 31). In addition to the typical minerals, minor minerals include hornblende, oxides, microcline, clinozoisite, and epidote. Overall, this sample contains $\sim 6 \%$ metamorphic fragments, including phyllite, serpentinite, well-foliated, fine-grained chlorite-muscoviteschist, biotite schist, $\sim 4 \%$ mafic volcanic fragments, $\sim 3 \%$ felsic volcanic fragments, and $\sim 4 \%$ chert fragments. Volcanic fragments are too small to further classify using a petrographic microscope. There are clasts with myrmekitic texture, and quartz grains have minor Boehm lamellae. Grains are poorly sorted, sub-angular to angular, and have a low sphericity (Fig. 32).

Sample FS151 was collected $\sim 6 \mathrm{~km}$ south of FS280, between the Ruby CreekWindmill Point area and Tronsen Ridge (Fig. 30), and the outcrop is composed of 50\% fine-grained sandstone and 50\% shale interbeds (Fig. 33A). This sample was mapped as micaceous feldspathic to lithofeldspathic sandstone by Tabor et al. (1982); however, on a QFL diagram, the sample is a fine-grained subarkose (Fig. 31). In addition to the typical minerals, this sample has sericitized plagioclase, and folded biotite is common between quartz grains. Clinozoisite occurs in minor amounts. Overall, this sample contains $\sim 7 \%$ mafic volcanic rock fragments, $\sim 1 \%$ metamorphic fragments, including fine-grained 

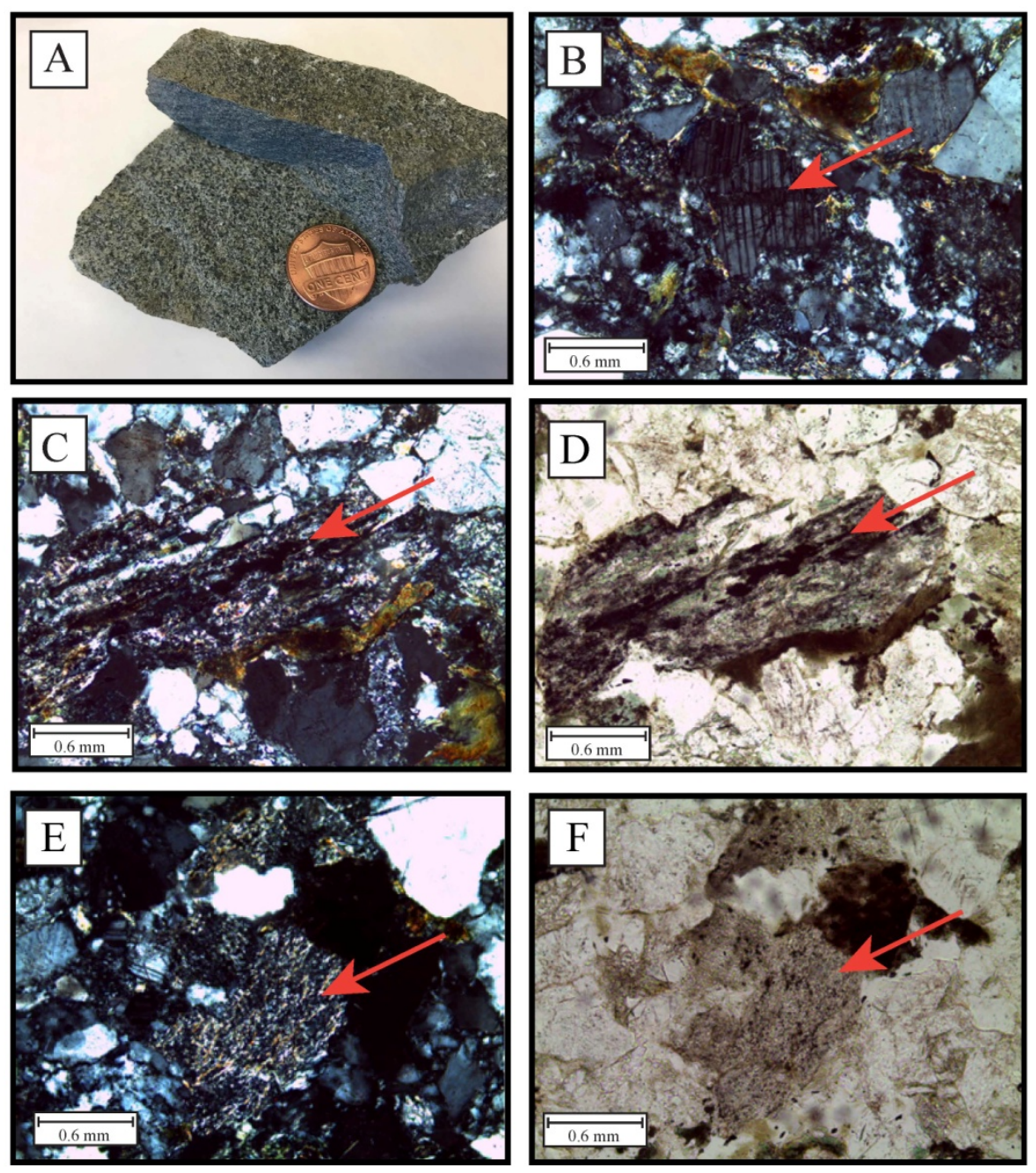

Figure 32. Sample FS280 of the Swauk Formation in the Ruby Creek-Windmill Point area. A) Hand sample. B) Fractured plagioclase in crossed polars. C) and D) Wellfoliated phyllite in crossed polars and plane light, respectively. E) and F) Fine-grained, well-foliated chloritic schist in crossed polars and plane light, respectively. 

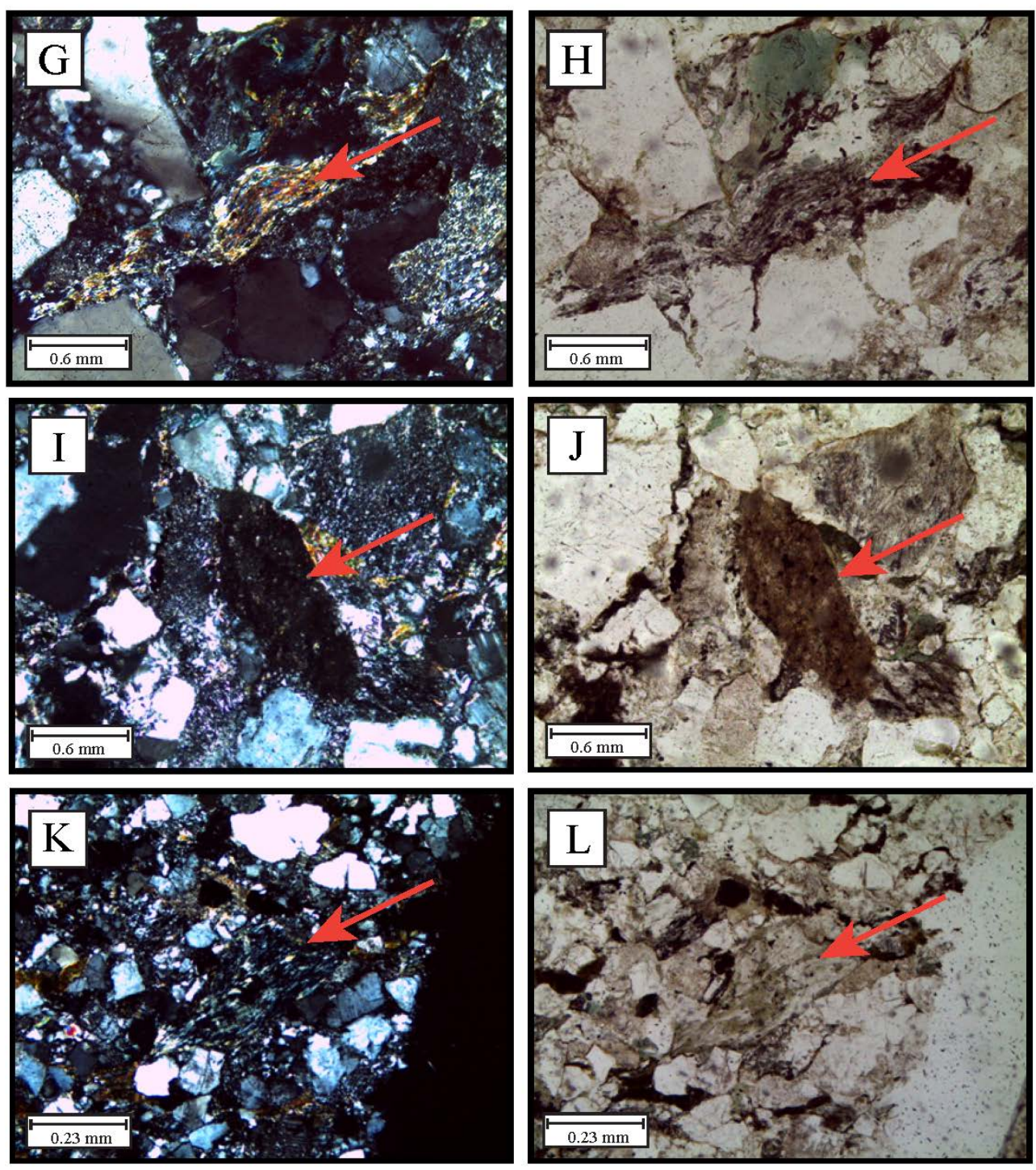

Figure 32 (continued). G) and H) Fine-grained, well-foliated biotite schist in crossed polars and plane light, respectively. I) and J) Fine-grained, mafic volcanic rock in crossed polars and plane light, respectively. K) and L) Serpentinite in crossed polars and plane light, respectively. 

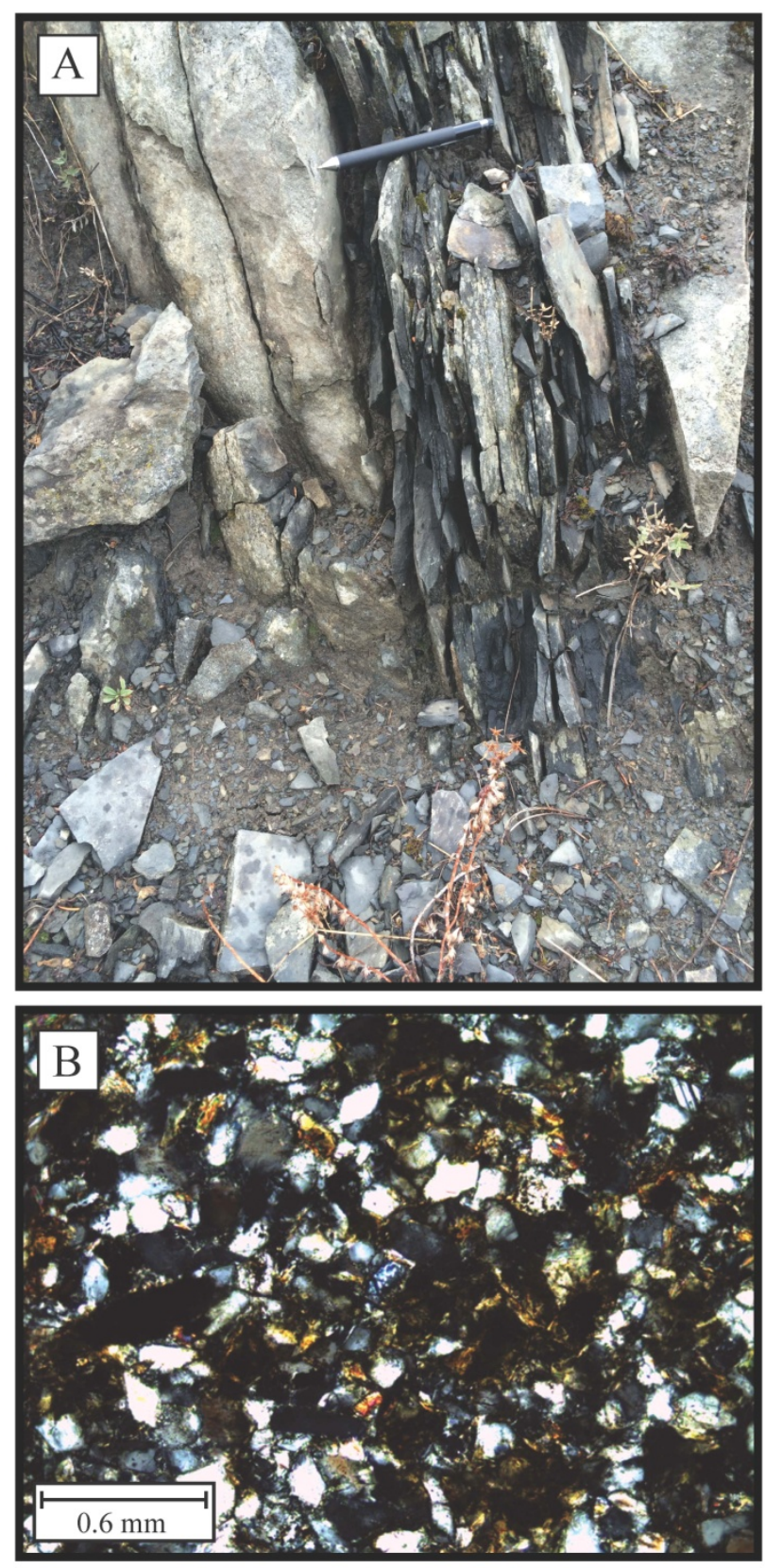

Figure 33: Sample FS151 of the Swauk Formation between the Ruby Creek-Windmill Point area and Tronsen Ridge. A) Outcrop of sandstone and shale interbeds. B) Sample FS151 under crossed polars showing well-sorted grains. 
micaceous quartzite with elongate quartz and fine-grained, well-foliated phyllite, and $0 \%$ felsic volcanic fragments. This fine-grained $(\sim 1 / 4-1 / 8 \mathrm{~mm})$ sandstone is very well sorted and clast supported, and grains are angular with a high sphericity (Fig. 33B).

Sample FS149 was collected $\sim 1 \mathrm{~km}$ south of FS151, between Ruby Creek and Tronsen Ridge (Fig. 30) from an outcrop of fine-grained, thinly bedded, grey sandstone. Common minerals are present as well as minor clinozoisite. Overall, rock fragments average $\sim 22 \%$ of this sample, and include chert and two types of metamorphic rock fragments: fine-grained micaceous quartzite with elongate quartz and fine-grained, wellfoliated phyllite. This sandstone is clast supported and very poorly sorted to poorly sorted; grains have low sphericity, and the sandstone is mostly fine to medium grained with some coarse grains (Fig. 34).

Sample FS147 was collected $\sim 1 \mathrm{~km}$ south of FS149 (Fig. 30) from an outcrop of thinly bedded, fine-grained sandstone. On a QFL diagram, this sample is a lithic arkose (Fig. 31). In addition to the typical minerals, muscovite, folded chlorite, epidote, and minor clinozoisite are also present. Quartz and biotite grains are moderately aligned (Fig. 35 ). Overall, this sample contains $\sim 8 \%$ metamorphic rock fragments, including phyllite, $\sim 2 \%$ mafic volcanic clasts, $\sim 2 \%$ felsic volcanic clasts, some of which are altered by chlorite, and even smaller amounts of chert $(\sim 1 \%)$. This sandstone is matrix supported or supported by rock fragments compacted between the grains. Grains are very well sorted, equigranular, subrounded, and have a moderate to high sphericity (Fig. 35).

Sample FS140 (MDA $=51.6 \pm 1.3$ Ma.) of the upper Tronsen Ridge Member (Fig. 30) was collected $\sim 3 \mathrm{~km}$ south of FS149, from an outcrop of 50\% medium-grained 

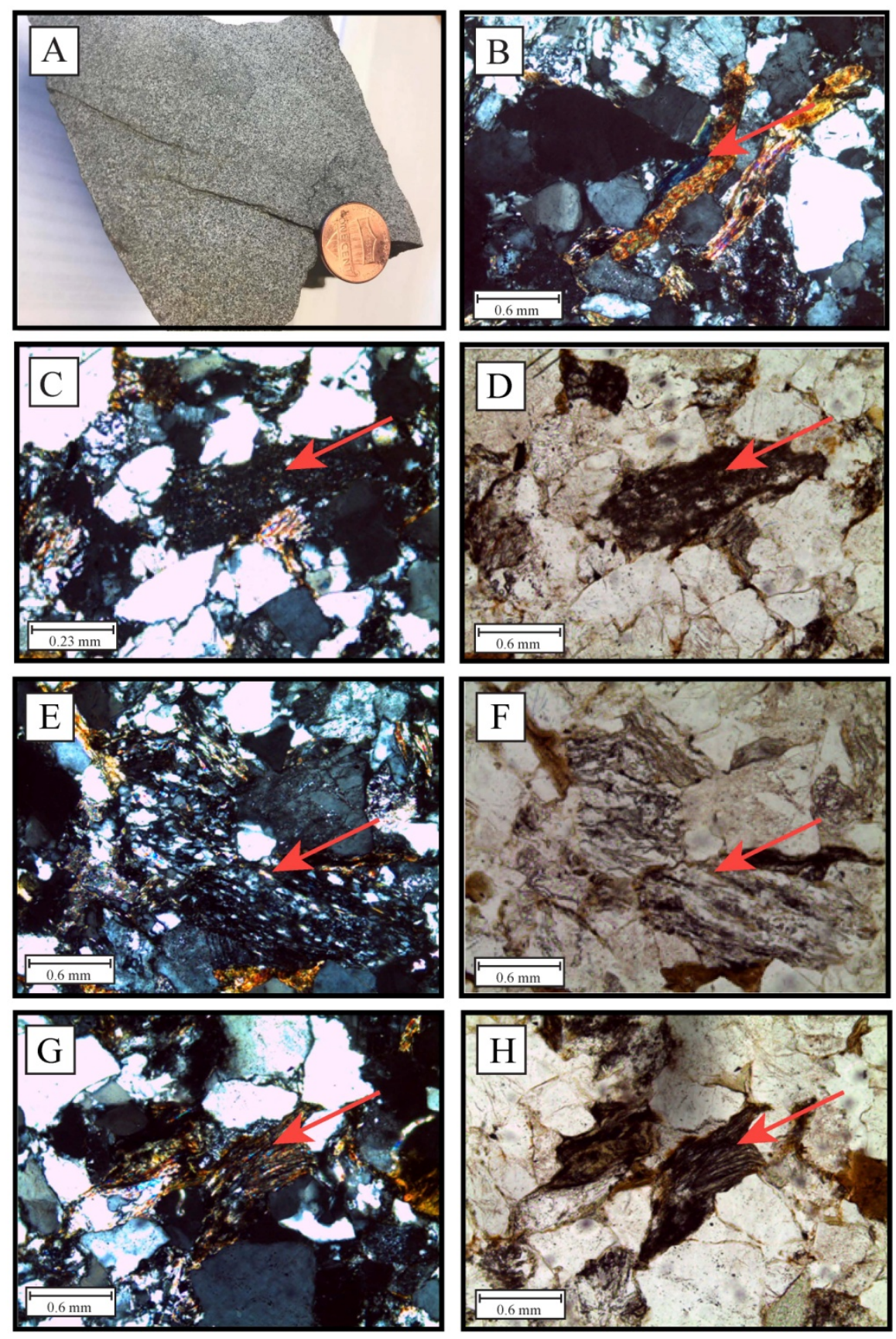

Figure 34. Sample FS149 of the Swauk Formation between the Ruby Creek-Windmill Point area and Tronsen Ridge. A) Hand sample. B) Folded biotite and chloritized biotite in crossed polars. C) and D) Mafic volcanic fragment in crossed polars and plane light, respectively. E) and F) Fine-grained micaceous quartzite with elongate quartz in crossed polars and plane light, respectively. G) and H) Muscovite-bearing phyllite in crossed polars and plane light, respectively. 

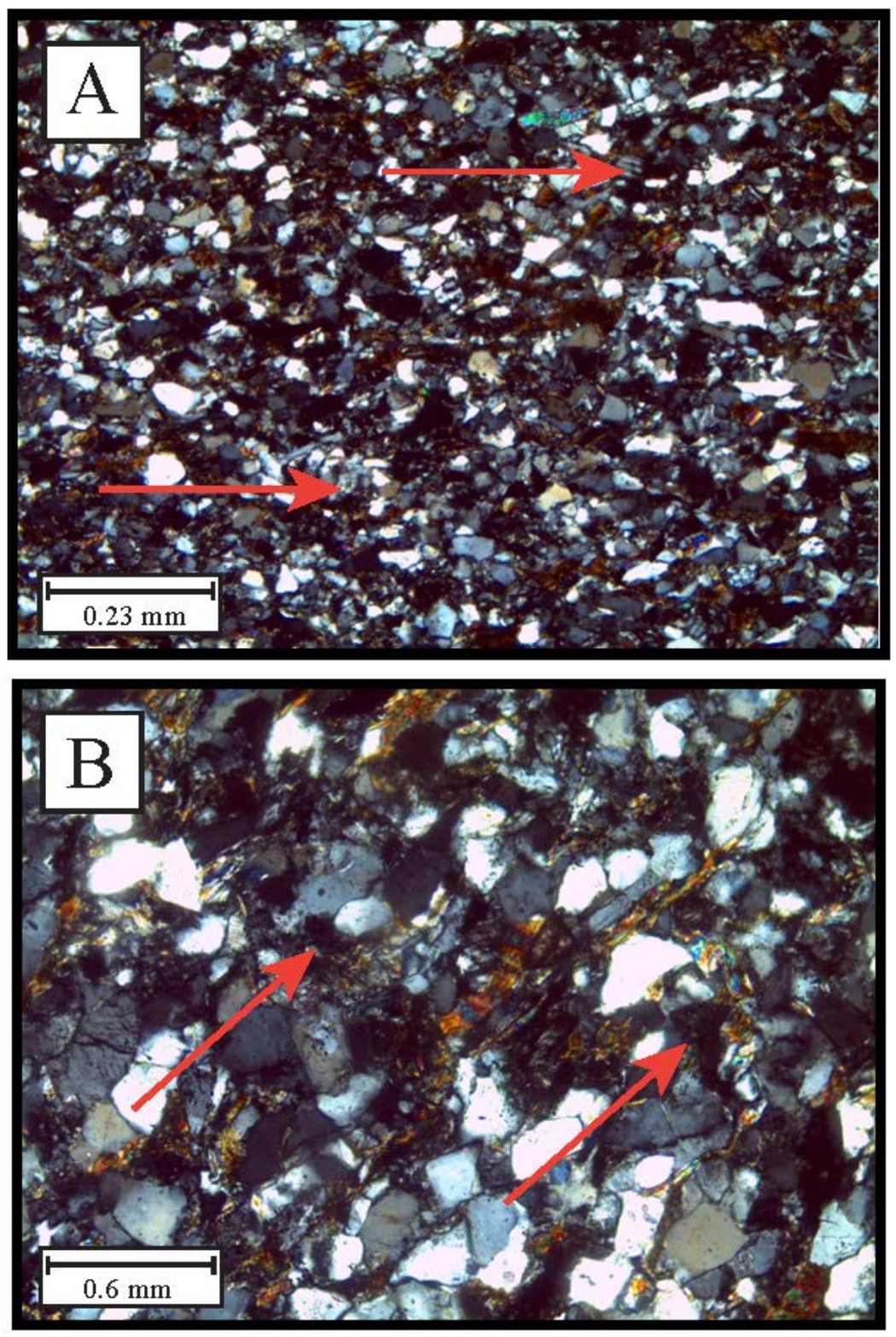

Figure 35. Sample FS147 of the Swauk Formation between the Ruby Creek-Windmill Point area and Tronsen Ridge. A) and B) Alignment of grains in crossed-polars, indicated by the red arrows. 
sandstone and 50\% shale interbeds. On a QFL diagram, this sample is a feldspathic litharenite (Fig. 31). In addition to the typical minerals, microcline, hornblende, and minor clinozoisite are present. Plagioclase is sericitized and fractured, and myrmekitic texture is common. A cataclastic band cuts through the sample. Overall, this sample contains $\sim 7 \%$ felsic rock fragments, $\sim 5 \%$ mafic rock fragments, $\sim 5 \%$ metamorphic rock fragments, $\sim 5 \%$ chert, and $\sim 5 \%$ unidentified lithics. Volcanic fragments are extensively altered by chlorite. This sandstone is clast supported and has a clay matrix; grains are poorly sorted and angular with moderate sphericity (Fig. 36).

Sample FS145 $(\mathrm{MDA}=50.46 \pm 0.17 \mathrm{Ma})$ of the upper Tronsen Ridge Member was collected $\sim 1 \mathrm{~km}$ south of FS147 (Fig. 30) from an outcrop of medium-grained sandstone. On a QFL diagram, this sample is a lithic arkose (Fig. 31). In addition to the typical minerals, apatite and tourmaline are present in minor amounts. Plagioclase albite law twinning, minor strain lamellae in feldspars, and sericitized plagioclase are present. Overall, this sample contains $\sim 5 \%$ metamorphic fragments, including graphitic biotite phyllite, and quartz-muscovite-biotite-phyllite, $\sim 4 \%$ felsic volcanic fragments, $\sim 3 \%$ sedimentary fragments, and $\sim 2 \%$ mafic volcanic fragments. Many volcanic fragments have porphyritic texture. This sandstone is clay supported and moderately sorted, and grains are sub-angular to sub-rounded with low sphericity (Fig. 37).

Sample FS224 of the lower Tronsen Ridge Member was collected $4 \mathrm{~km} \mathrm{SE} \mathrm{of}$ FS140 (Fig. 30) from an outcrop of coarse-grained, cross-bedded sandstone. On a QFL diagram, this sample is a lithic arkose (Fig. 31). In addition to the typical minerals, clinozoisite and epidote occur and myrmekitic texture is present. Secondary calcite 

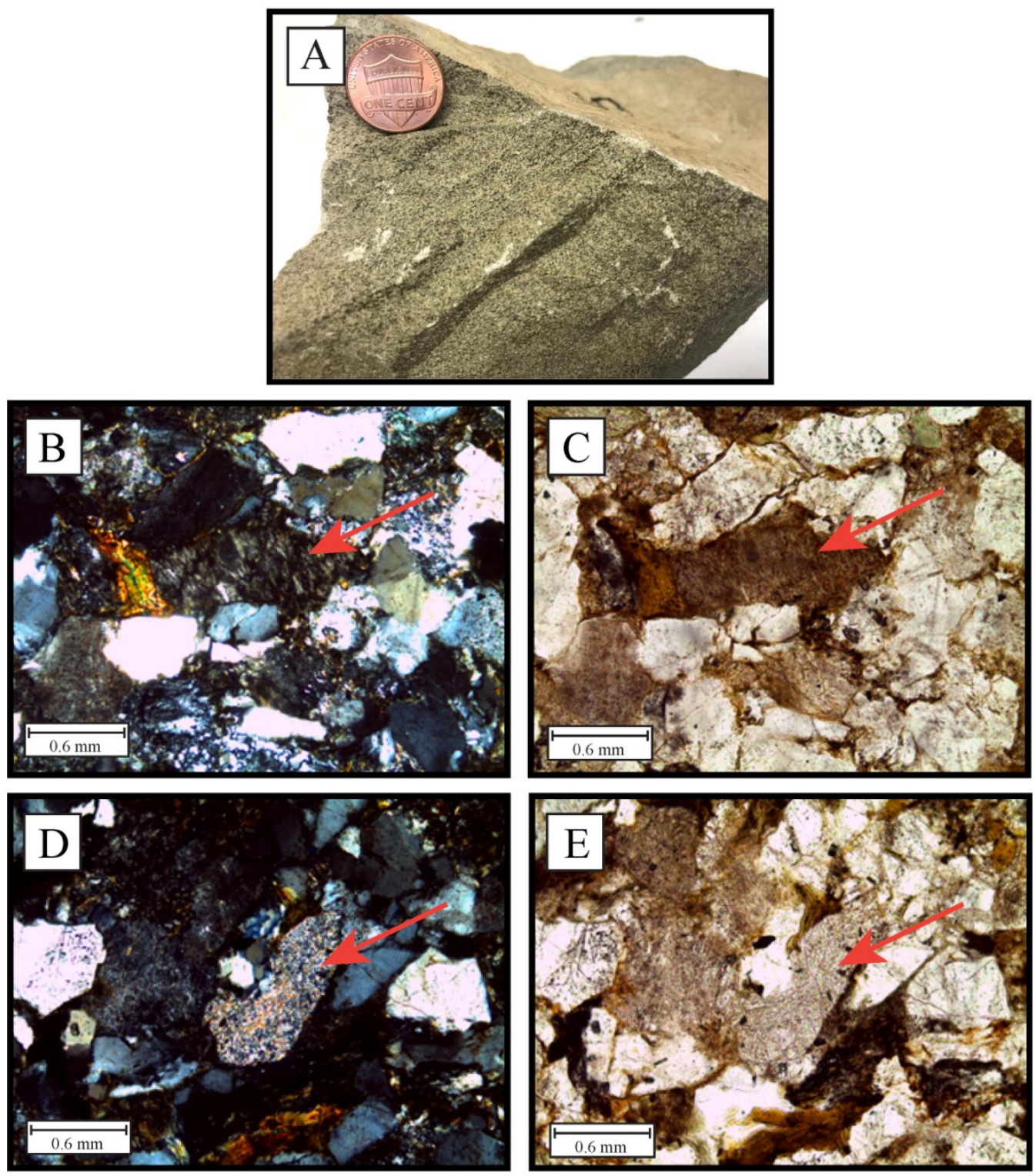

Figure 36. Sample FS140 of the upper Tronsen Ridge Member of the Swauk Formation. A) Hand sample. B) and C) Mafic volcanic rock fragments altered by chlorite in crossed polars and plane light, respectively. D) and E) Felsic volcanic rock fragment altered by chlorite in crossed polars and plane light, respectively. 

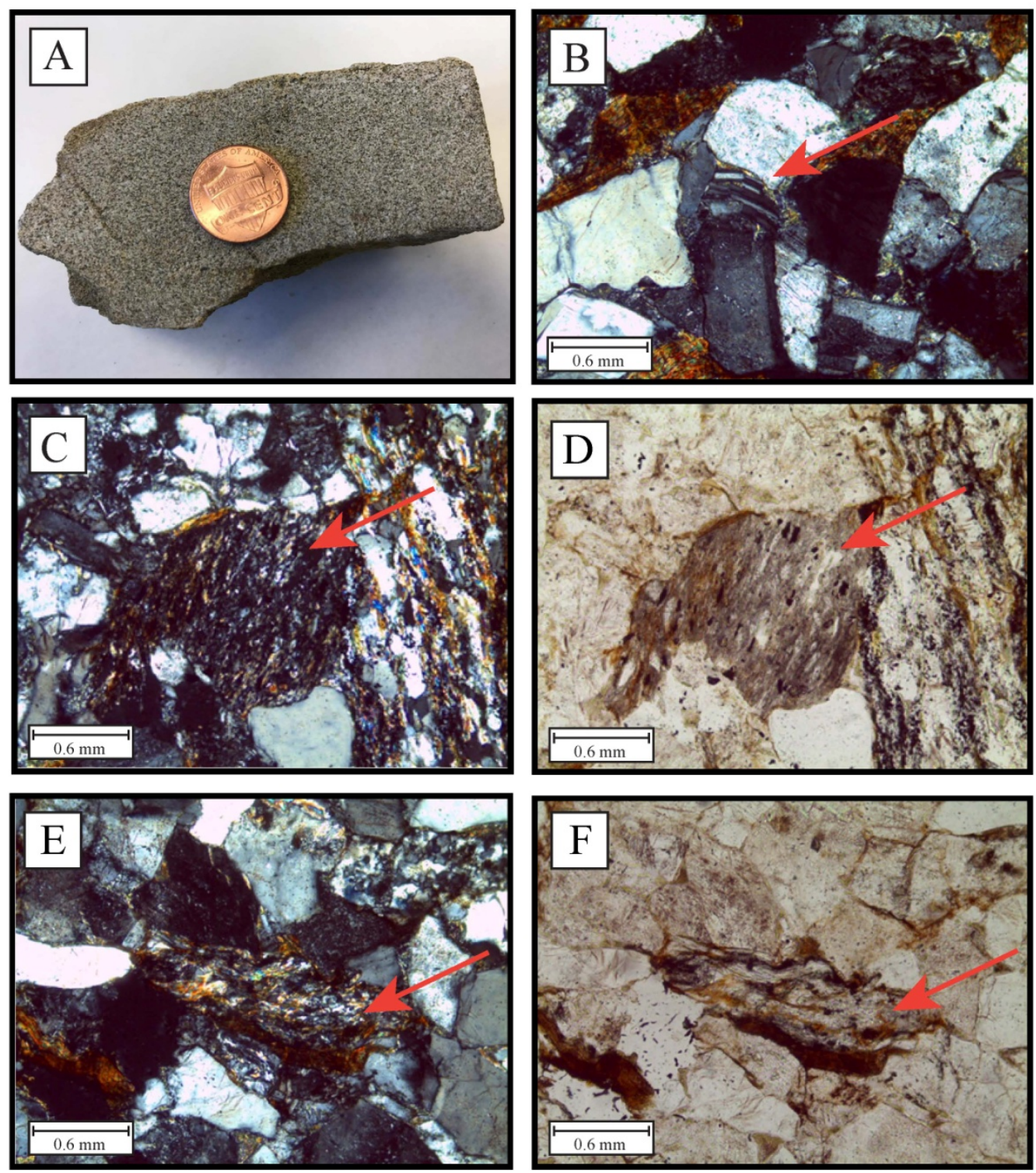

Figure 37. Sample FS145 of the upper Tronsen Ridge Member of the Swauk Formation. A) Hand sample. B) A kink fold of a plagioclase crystal. C) and D) Graphitic biotite phyllite in cross polars and plane light, respectively. E) and F) A low grade, foliated, metamorphic rock (unable to differentiate further) fragment with biotite in crossed polars and plane light, respectively. 
occurs in some rock fragments and some plagioclase grains are fractured. This sample contains $\sim 10 \%$ felsic volcanic rock fragments, $\sim 6 \%$ mafic volcanic rock fragments, $\sim 6 \%$ chert, and $\sim 3 \%$ metamorphic rock fragments. Diabase is also present in minor amounts and volcanic fragments are commonly altered by chlorite. This sandstone is clast supported and mostly coarse grained. Grains are well to moderately sorted, and angular with moderate sphericity (Fig. 38).

Sample FS224A of the lower Tronsen Ridge Member is a coarse-grained sandstone concretion collected in the same outcrop as sample FS224 (Fig. 30). On a QFL diagram, this sample is a lithic arkose (Fig. 31). In addition to the typical minerals, minor muscovite, and rare clinozoisite are also present. Fractured grains are common. Overall, this sample contains $\sim 5 \%$ chert, $\sim 6 \%$ mafic volcanic fragments, $\sim 5 \%$ felsic volcanic fragments rich in biotite and quartz, and $\sim 2 \%$ metamorphic rock fragments, including graphitic schist and biotite-bearing phyllite. Diabase is also present in minor amounts. This sample contains 7\% less rock fragments than sample FS224. This difference can be attributed to the removal of these fragments due to replacement by carbonates, or the compaction of rock fragments between grains in sample 224A. Sample 224A has calcite cement and is matrix supported. Grains are poorly sorted, and angular with low sphericity (Fig. 39).

\section{Chumstick Formation}

Two samples were point counted from the Devil's Gulch Member of the Chumstick Formation, including a sample from the northern segment of the member near Camas Creek (FS13) and another southwest of Beehive Reservoir (FS253) (Fig. 30). These 

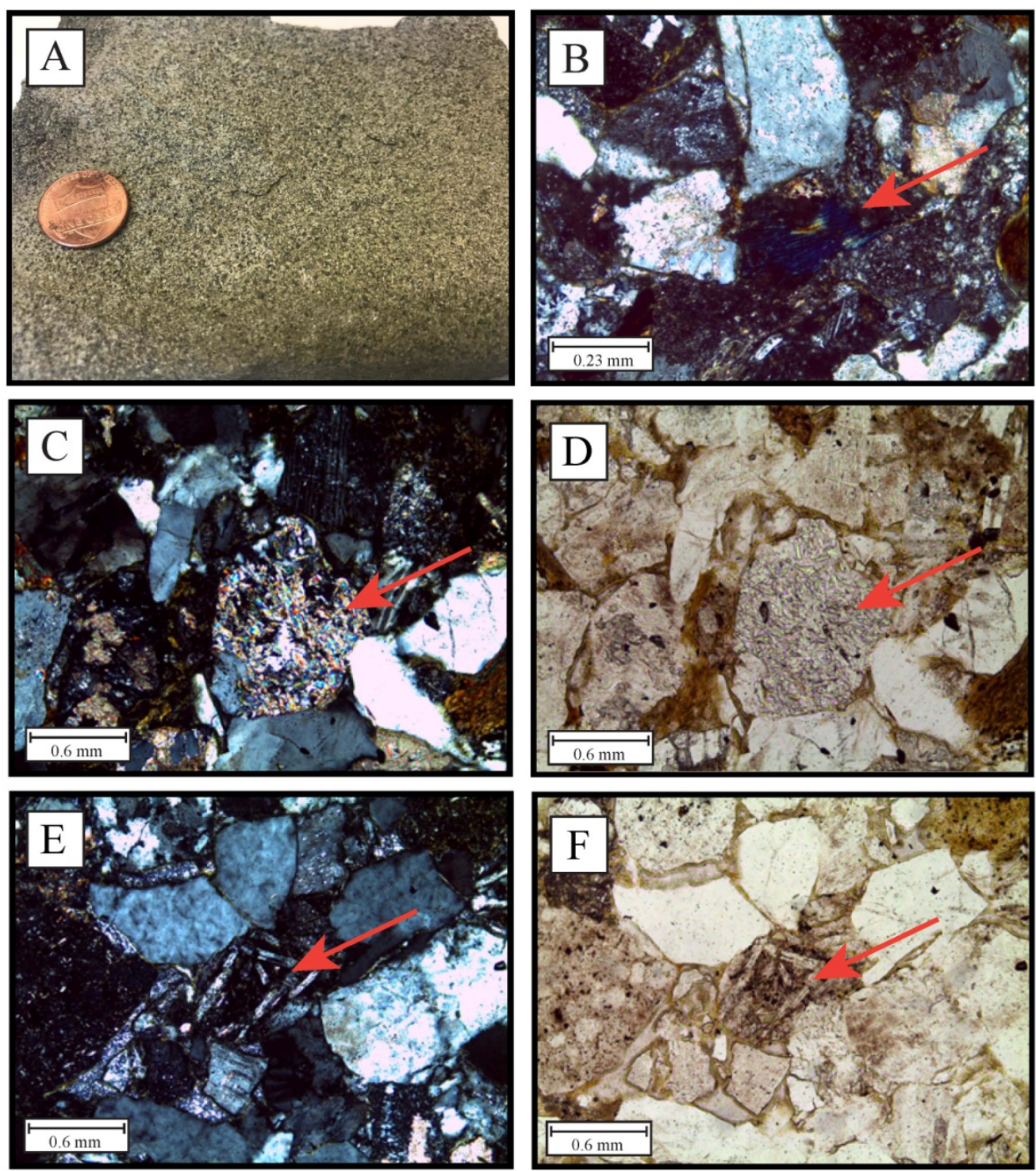

Figure 38. Sample FS224 of the lower Tronsen Ridge Member of the Swauk Formation. A) Hand sample. B) Chloritized biotite. C) and D) Felsic volcanic rock fragment altered by chlorite in crossed polars and plane light, respectively. E) and F) A diabase fragment in crossed polars and plane light, respectively. 

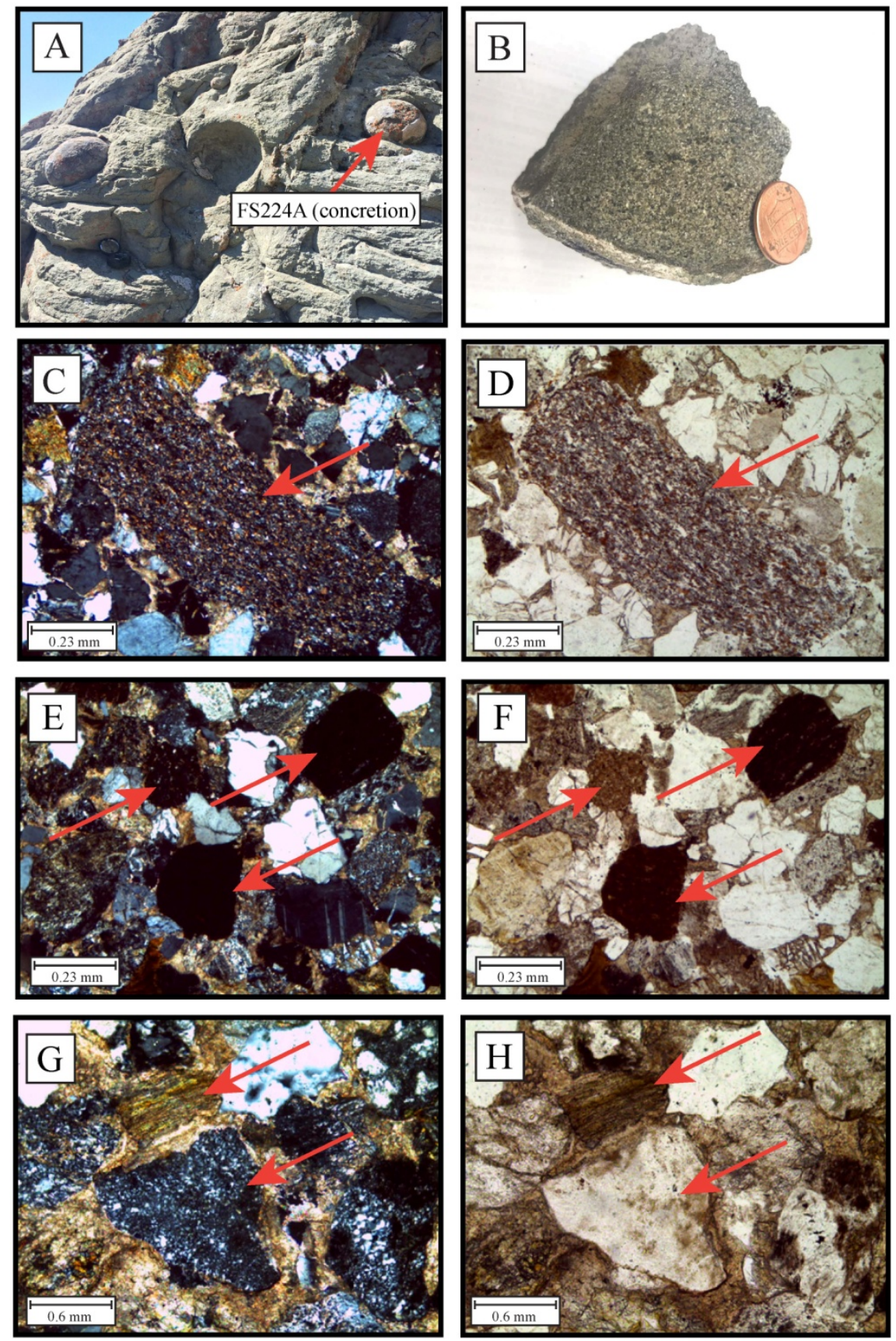

Figure 39. Sample FS224A of the lower Tronsen Ridge Member of the Swauk Formation. A) Outcrop FS224 and concretions FS224A. B) Hand sample of sandstone concretion. C) and D) Fine-grained graphitic schist in crossed polars and plane light, respectively. E) and F) Mafic volcanic rock fragments in crossed polars and plane light, respectively. G) and $\mathrm{H}$ ) Fine-grained, metamorphic rock fragment rich in biotite (upper) and a chert fragment (lower) in crossed polars and plane light, respectively. 
samples consist dominantly of quartz, plagioclase, and micas. Mineral modes for quartz range from $\sim 34-80 \%$ and average $\sim 57 \%$, plagioclase ranges from $\sim 8-35 \%$ with an average of $\sim 22 \%$, and biotite ranges from $\sim 6-10 \%$ with an average of $\sim 8 \%$. Biotite is commonly folded. These two samples are described individually in detail below.

Sample FS13 was collected $\sim 0.5 \mathrm{~km}$ east of the Ingalls Complex (Fig. 30) and is a siltstone interbed within the conglomerate of the Devil's Gulch Member. The outcrop is fine-grained and dips west. This sample contains recrystallized and moderately elongate quartz with sutured boundaries, and smaller amounts ( $6 \%)$ of detrital muscovite between the quartz grains. Granoblastic texture is present in some quartz grains and bedding is evident by a change from fine to medium grain size (Fig. 40). There are no visible rock fragments.

Sample FS253 (MDA $=86.9 \pm 2.0$ Ma.) was collected $\sim 3 \mathrm{~km} \mathrm{SW}$ of Beehive Reservoir within the Leavenworth fault zone (Fig. 30) and is conglomerate of the Devil's Gulch Member (Tabor et al., 1982). This sample contains biotite crystals ranging in length from $\sim 1-5 \mathrm{~mm}$, and quartz crystals ranging in length from $\sim 1 \mathrm{~mm}-1 \mathrm{~cm}$. In addition to the typical minerals, minor tremolite, muscovite, and clinozoisite are present. The rock contains abundant folded biotite, minor clasts with myrmekite texture, sericitized plagioclase, and calcite replacement of feldspar. Overall, this sample contains $\sim 5 \%$ chert, $\sim 3 \%$ felsic volcanic fragments, $\sim 1 \%$ mafic volcanic fragments, and $\sim 4 \%$ metamorphic rock fragments. Volcanic fragments are commonly altered by chlorite. This sample is framework supported and lacks porosity; grains are very poorly sorted to 

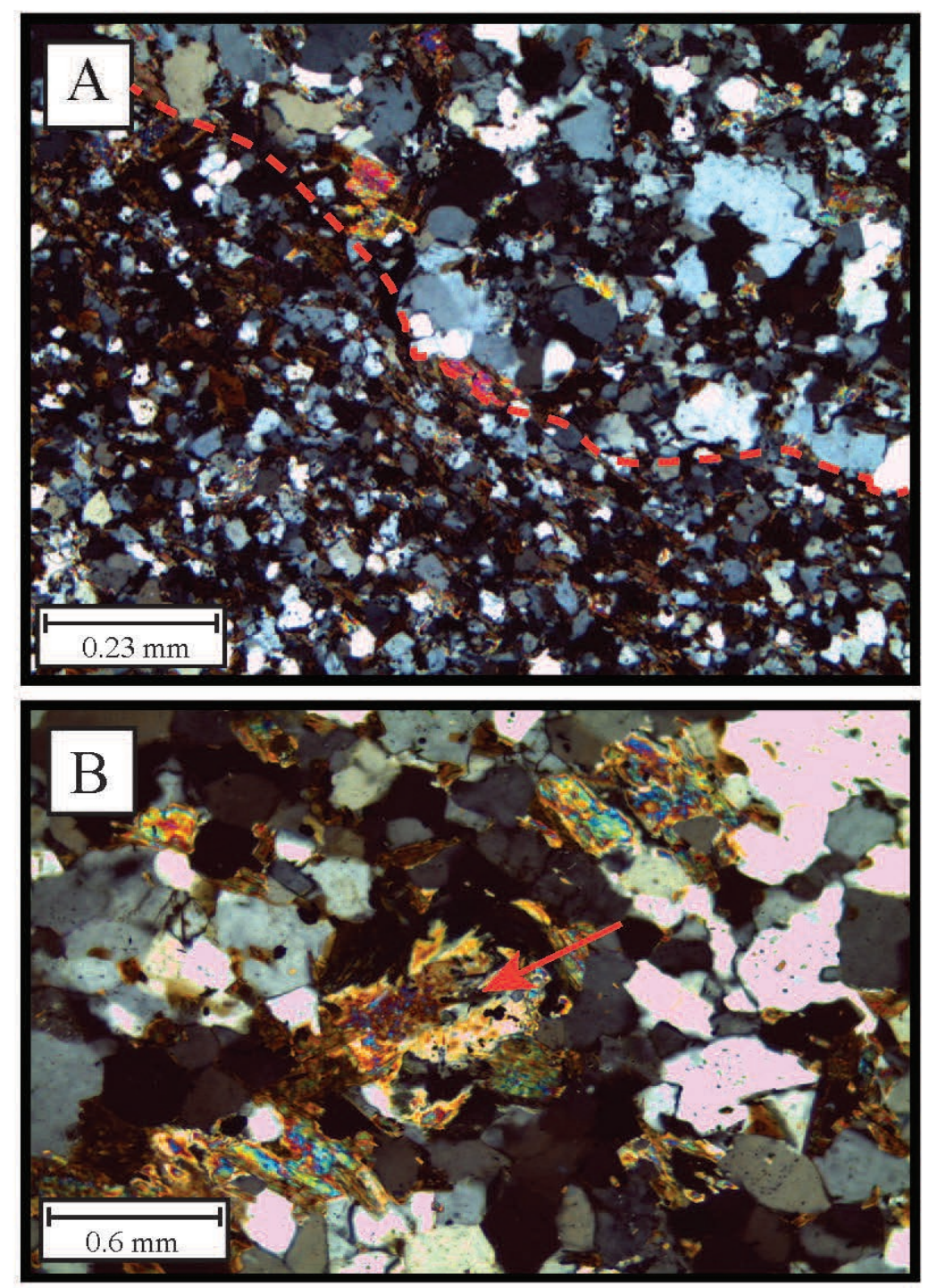

Figure 40. Sample FS13 of Devil's Gulch Member of the Chumstick Formation near Camas Creek. A) Bedding defined by difference in grain size is roughly marked by the dashed red line; in crossed polars. B) Detrital muscovite between sutured, recrystallized quartz marked by the red arrow; in crossed polars. 
poorly sorted, very fine to very coarse grained, and are very angular with low sphericity (Fig. 41).

\section{Teanaway Dikes}

The early Eocene ( 49.3 Ma; Eddy et al., 2016) Teanaway Formation consists of basaltic flows, breccias and tuffs, and minor rhyolites and fluvial sedimentary rocks (Tabor et al., 1984, 2000). Abundant dikes intruding the Swauk Formation are referred to as Teanaway dikes (Foster, 1958; Tabor et al., 1982, 1984) and are interpreted to be synchronous with the volcanic rocks of the Teanaway Formation. In the study area, Teanaway dikes are common in the northern transects, such as in the Ruby CreekWindmill Point area, and are rare in the Tronsen Ridge area.

Four dike samples were collected in the Ruby Creek-Windmill Point area at stations FS56, FS58, FS105, and FS107 (Fig. 30). In hand sample, the dikes are aphanitic and equigranular, with the exception of FS107, which is mildly porphyritic, displaying $\sim 0.5 \mathrm{~mm}$ long plagioclase crystals. Colors range from tan, to purplish-gray, to dark gray.

In thin-section (Fig. 42), dikes consist dominantly of plagioclase laths, and secondary biotite and chlorite; minor quartz occurs in some dikes. Clinopyroxene and hornblende are the dominant primary mafic minerals. In addition, FS56 contains oxides, FS105 has apatite needles (Fig. 42D), suggesting quenching, and FS107 has sizable $(\sim 0.7 \mathrm{~mm})$ and abundant $(\sim 15 \%)$ quartz, and hornblende replaced by biotite. Extensive low-temperature alteration prevents further analysis (Fig. 42). These observations are in accordance with those of Doran (2009) and Foster (1958). 


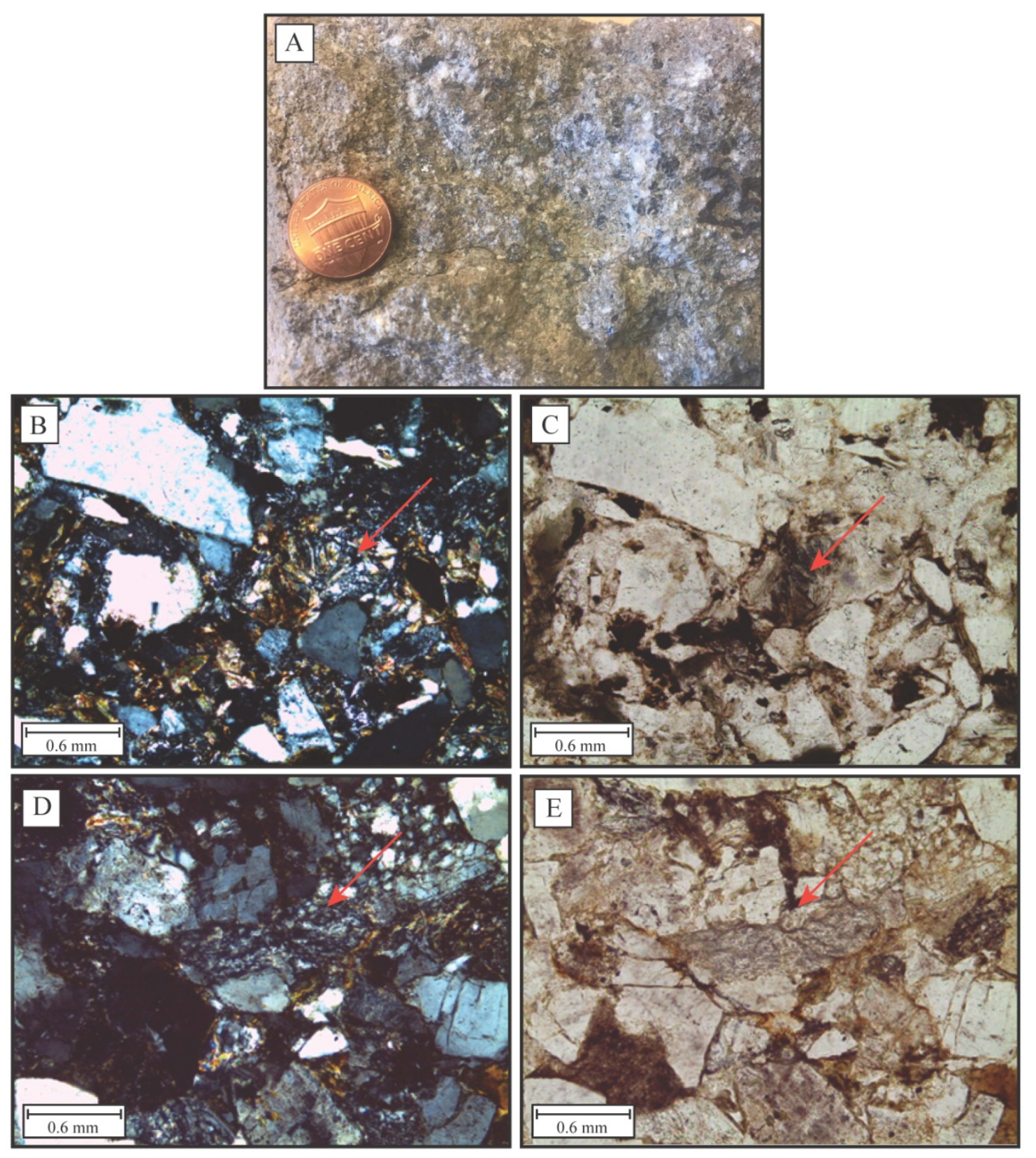

Figure 41. Sample FS253 of the Chumstick Formation southwest of Beehive Reservoir. A) Hand sample. B) and C) Felsic volcanic rock fragment altered by chlorite in crossed polars and plane light, respectively. D) and E) Chert in crossed polars and plane light, respectively. 

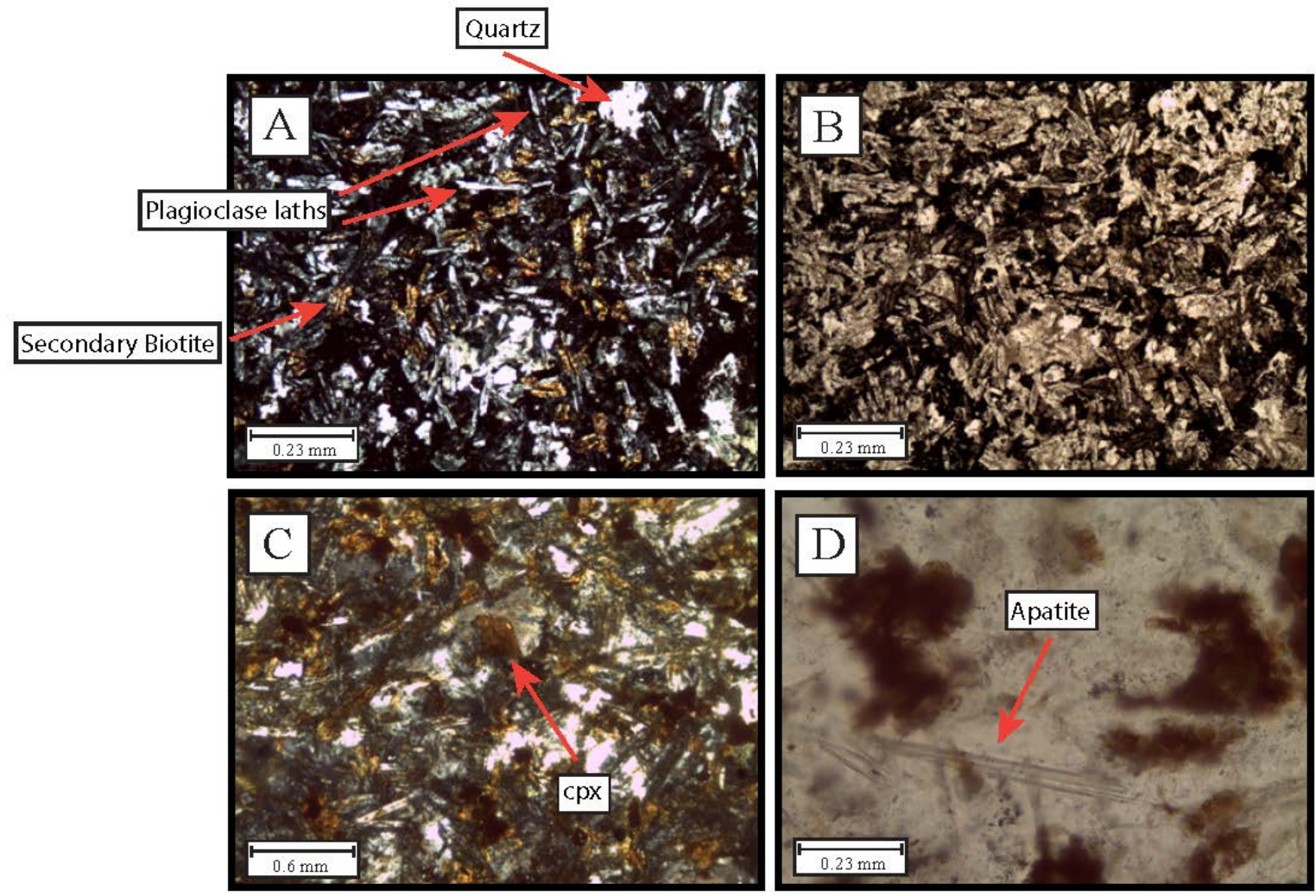

Figure 42. Photomicrographs of Teanaway dikes. A) and B) Dike showing common minerals under cross polars and plane light, respectively. C) Clinopyroxene in sample FS56. D) Apatite needles in sample FS105. 


\section{GEOCHRONOLOGY AND PROVENANCE OF UNITS}

The goal of the detrital zircon geochronology carried out for this study is to determine maximum depositional age and rock provenance of sandstones in and near the Leavenworth fault zone. Dating sandstone samples from different stratigraphic locations was conducted using Back-Scattered Electron (BSE) imaging and LA-ICPMS at the LaserChron lab in Tucson, Arizona. Four Swauk samples (FS280, FS140, FS145, FS147) and one Chumstick sample (FS253) were processed. One zircon from sample FS145 was re-evaluated using high precision CA-ID-TIMS (see methods) by M. Eddy (Fig. 30). See Appendix A for a list of UTM locations of dated samples.

The geochronological data from this study, along with paleocurrent data (Fraser, 1985; Taylor et al., 1988), imply that the dated detritus reflects a local provenance. Paleocurrent data and ages from tuffs suggest that Swauk sediment was predominantly derived from the north and northeast between $\leq 59.9$ and $\sim 51.3 \mathrm{Ma}$, and was followed by a reversal in paleoflow direction from the southwest between $\sim 51.3$ and $49.9 \mathrm{Ma}$ (Frizzell, 1979; Tabor et al., 1984; Eddy et al., 2016).

The potential sources for the Swauk Formation to the north and northeast are largely rocks of the Cascades crystalline core and the Okanogan Range batholith (Figs. 2 and 43). The adjacent Wenatchee block of the core is characterized by 96-86 Ma plutons that intrude the Early Cretaceous Chiwaukum Schist of the Nason terrane and Jurassic Ingalls Ophiolite (Figs. 2 and 43; Table 3) (Tabor et al., 1982, 1989; Miller, 1985; Miller et al., 2009a, 2016). The Chelan block of the Cascades crystalline core (Figs. 2 and 43; Table 3) consists mainly of 96-45 Ma plutons and meta-supracrustal rocks, including the Late 

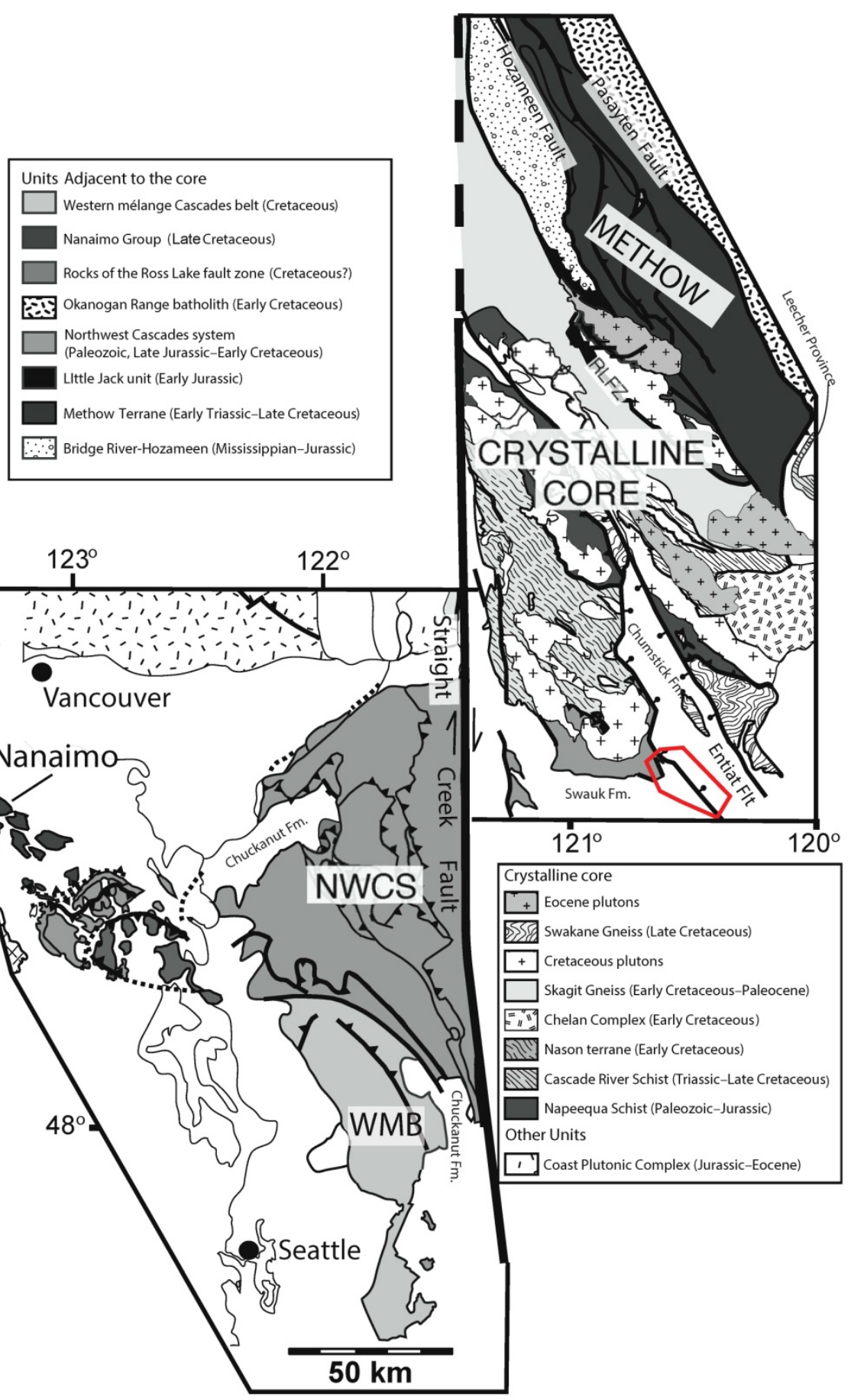

Figure 43. Geologic map emphasizing potential sources for Eocene clastic rocks and rocks in the Cascades core and adjacent units. Note location of study area (in red). Dextral strike-slip motion on the Straight Creek fault is restored to the maximum offset estimate $(\sim 170 \mathrm{~km})$. NWCS=Northwest Cascades System, RLFZ=Ross Lake fault zone, $\mathrm{WMB}=$ western mélange belt. Figure modified from Gordon et al. (2017). 
Table 3. Overview of the crystallization ages of plutons in the Cascades core.

\begin{tabular}{ll} 
Chelan Block Plutons & Age (Ma) \\
\hline Oval Peak & 65 \\
Entiat & $73-71$ \\
Jordan Lakes & 74 \\
Hidden Lake & 75 \\
Cardinal Peak & $78-72$ \\
High Pass & 88 \\
Bearcat Ridge & 89 \\
Eldorado & 90 \\
Black Peak & $92-87$ \\
Seven-Fingered-Jack & 92 \\
Sulphur Mountain & 96 \\
Chelan Complex & Early Cretaceous \\
Wenatchee Block Plutons & Age (Ma) \\
\hline Sloan Creek & 90 \\
Mount Stuart & $96-91$ \\
Beckler Peak & 91 \\
Dirtyface & 91 \\
Tenpeak & $92-89$ \\
Wenatchee Ridge & 93 \\
Unfocused Magmas & Age (Ma) \\
\hline Napeequa Sheets & $88-71$ \\
Cascade River Sheets & $90-72$ \\
Nason Terrane Sheets & 90 \\
Skagit Orthogneiss & $76-48$ \\
\hline
\end{tabular}

Note: Ages from Misch (1966), Miller and Bowring (1990), Walker and Brown (1991) Hurlow (1992), Matzel (2004), Matzel et al. (2006), Miller et al. (2009a, 2016), and Shea et al. (2017). 
Cretaceous Swakane Biotite Gneiss, the Paleozoic-Jurassic Napeequa unit, the TriassicLate Cretaceous Cascade River Schist-Holden unit, and orthogneisses of various ages (Table 4). Some of these units also occur in the northern part of the Wenatchee block (Tabor et al., 1989, 2003; Brown et al., 1994; Miller et al., 1994). Other sources to the east of the Cascades core include the Jurassic-Late Cretaceous clastic rocks of the Methow terrane (e.g., Barksdale, 1975; DeGraaff-Surpless et al., 2003; Surpless et al., 2014). Potential sources to the west of the Cascades core for the southwest-derived detritus are the Late Cretaceous sedimentary rocks of the Nanaimo Group, sandstones and plutonic rocks of the Cretaceous western mélange belt, and the Late Paleozoic-Early Cretaceous Northwest Cascades system (Misch, 1966; Brandon, 1988; Brown et al., 1994; Mustard, 1994; Brown and Gehrels, 2007) (Fig. 43). Age clusters and sources for each sample are discussed below.

\section{Swauk Formation}

Detrital zircons ( $\mathrm{n}=108)$ were dated from sample FS280 from the Ruby CreekWindmill Point area located in the northeastern part of the Swauk Formation (Fig. 30). This sample has a MDA of $67.2 \pm 1.9 \mathrm{Ma}$. The youngest and most prominent peak is $\sim 73$ Ma, followed by peaks of $\sim 88 \mathrm{Ma}$ and $\sim 110 \mathrm{Ma}$, and a few $\sim 168 \mathrm{Ma}$ and $\sim 208$ Ma grains (Fig. 44).

The youngest, $\sim 73$ Ma peak probably has a local source in the Chelan block. Potential sources of this age in the block include the Entiat pluton, Cardinal Peak pluton, and orthogneiss in the Skagit Gneiss Complex (Haugerud et al., 1991; Miller et al., 2016) (Tables 3 and 4$)$. The Cretaceous peaks ( $88 \mathrm{Ma}, \sim 110 \mathrm{Ma})$ could be derived from a 
Table 4. Overview of detrital zircon ages of metamorphic units in the Cascades core.

\begin{tabular}{|c|c|c|}
\hline Host Rock & Depositional Age (Ma) & Detrital Zircon Age Peaks (Ma) \\
\hline Swakane Biotite Gneiss & $\begin{array}{l}\text { Late Cretaceous, MDAs: } \sim 91-87 \\
\mathrm{Ma}, \sim 82-78 \mathrm{Ma} .\end{array}$ & $\begin{array}{l}1.8-1.6 \mathrm{Ga}, 1.4-1.3 \mathrm{Ga}, 100-90 \\
160-150 \mathrm{Ma}, 120 \mathrm{Ma} \text {. }\end{array}$ \\
\hline Skagit Gneiss Complex & $\begin{array}{l}\text { Early Cretaceous- Paleocene, } \\
\text { MDAs: } \sim 134, \sim 124, \sim 121, \sim 115 \text {, } \\
\sim 112, \sim 108, \sim 96 \mathrm{Ma} .\end{array}$ & Proterozoic-Late Cretaceous \\
\hline Chiwaukum Schist & $\begin{array}{l}\text { Early Cretaceous, MDA: } 125 \\
\text { Ma. }\end{array}$ & 152,125 \\
\hline $\begin{array}{l}\text { Cascade River Schist and } \\
\text { Holden unit }\end{array}$ & $\begin{array}{l}\text { Triassic-Late Cretaceous, } \\
\text { MDAs: } \sim 107, \sim 97, \sim 91 \mathrm{Ma} .\end{array}$ & $\begin{array}{l}230,205,190,165,150,120 \\
115,107,96,93\end{array}$ \\
\hline Ingalls Complex sediments & Late Jurassic & $155-164,150$ \\
\hline Napeequa Schist & Paleozoic-Jurassic & $245-225$ \\
\hline
\end{tabular}

Note: Ages from Haugerud et al. (1991), Walker and Brown (1991), Hurlow (1992), Matzel (2004), Brown and Gehrels (2007), Miller et al. (2009a, 2016), and Gordon et al. (2017). 

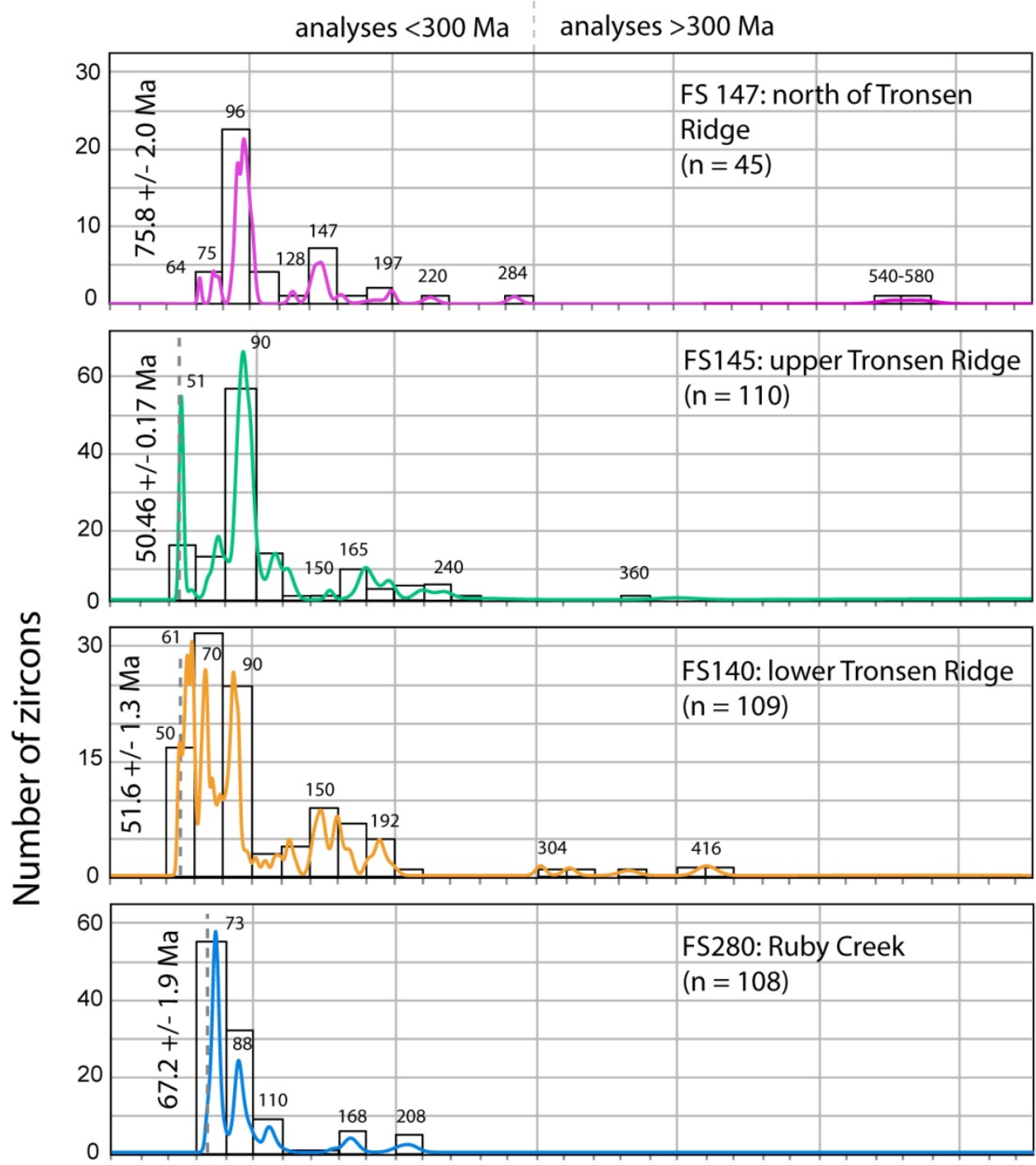

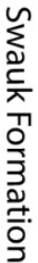

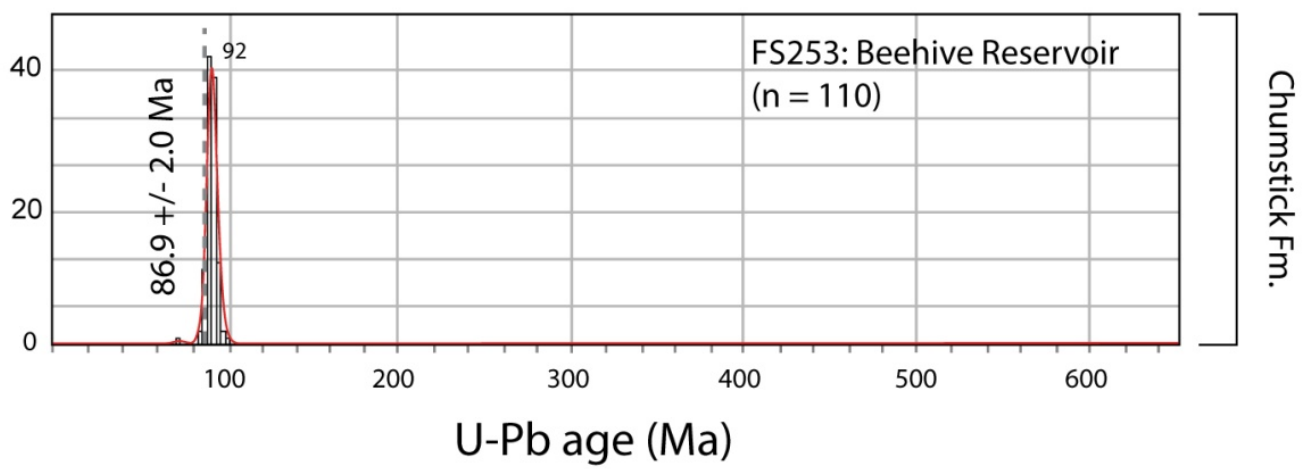

Figure 44. Relative probability plot of detrital zircon ages with MDAs for all dated samples. Swauk samples are arranged in stratigraphic order. 
combination of sources in the Wenatchee block and Chelan block to the northeast (Miller at al., 2009a) (Table 3). The $\sim 110$ Ma peak also has a potential source in the $\sim 120-110$ Ma Okanogan Range batholith (Hurlow, 1993), or represent reworked zircons from the Winthrop Formation and Jackass Mountain Group in the Methow basin (Surpless et al., 2014) (Fig. 43). The Middle Jurassic, 168 Ma grains have a potential Cascade River Schist source, with a detrital zircon age peak at $165 \mathrm{Ma}$ (Gordon et al., 2017) (Table 4). The $\sim 208$ Ma grains reflect numerous potential sources, including the Cascade River Schist and Holden unit, Little Jack unit, Dumbell Mountain plutons, and the Late Triassic Leecher metamorphics (Barksdale, 1975; Cater, 1982; Tabor et al., 1989, 2003; Miller et al., 1994; Gordon et al., 2017; Sauer et al., 2017) (Figs. 2 and 43; Table 4).

Detrital zircons ( $\mathrm{n}=109)$ from sample FS140 of the Swauk sandstone from the lower part of the Tronsen Ridge Member (Fig. 30) have peaks at $\sim 50 \mathrm{Ma}, \sim 60-70 \mathrm{Ma}$ and $\sim 90$ Ma, a broad spread with small peaks at $\sim 127 \mathrm{Ma}, \sim 150 \mathrm{Ma}$, and $\sim 192 \mathrm{Ma}$, scattered $\sim 304-420$ Ma grains, and a MDA of 51.6 $\pm 1.3 \mathrm{Ma}$ (Fig. 44).

The youngest $\sim 51$ Ma peak can be attributed to $51-43$ Ma Challis magmatism in northeastern Washington to Idaho (Dumitru et al., 2013), but is more likely sourced from the local 51.3 Ma Silver Pass tuff to the west (Eddy et al., 2016). The $\sim 61-70$ Ma cluster has a potential Chelan block source, such as the 76-59 Ma orthogneisses in the Skagit Gneiss Complex and the 65 Ma Oval Peak pluton (Miller at al., 2009a, 2016) (Tables 3 and 4). A number of plutons in the Wenatchee and Chelan blocks are possible sources for the $\sim 90$ Ma detrital zircons (See Fig. 2 and Table 3). The Cretaceous and Jurassic, $\sim 100$ 200 Ma grains may be derived from a combination of sources listed in Table 4, including: 
Mesozoic detrital zircons of the western mélange belt (Sauer et al., 2017), Late Jurassic Ingalls Ophiolite Complex of the Northwest Cascades system (NWCS) (Miller, 1985), the Late Cretaceous Nanaimo Group (Mustard, 1994; Matthews et al., 2017), the Okanogan Range batholith (Hurlow, 1993), and the Jurassic-Cretaceous strata of the Methow terrane (Surpless et al., 2014; Gordon et al., 2017) (Figs. 2, 43, and 44). The source for the Paleozoic, $\sim 300-360$ Ma and $\sim 400-420$ Ma grains is poorly constrained; these grains may have been derived from nappes of the NWCS (Brandon et al., 1988; Brown and Gehrels, 2007) (Fig. 43).

Detrital zircons ( $\mathrm{n}=110)$ for sample FS145, from the upper part of the Tronsen Ridge Member (Fig. 30), have peaks at $\sim 51 \mathrm{Ma}, \sim 90 \mathrm{Ma}$, a broad spread between $\sim 150-240 \mathrm{Ma}$ with peaks at $\sim 164.8 \mathrm{Ma}$ and $\sim 240 \mathrm{Ma}$, and a single grain at $\sim 360 \mathrm{Ma}$. This sample had a MDA of $49.7 \pm 1.2 \mathrm{Ma}$ from the LA-ICPMS dates. The youngest dated zircon was later picked and re-evaluated by CA-ID-TIMS, providing a more precise MDA of $50.46 \pm 0.17$ Ma (M. Eddy, written communication).

The magmatic rocks from the $51.36 \pm 0.03$ Ma Silver Pass Member are likely responsible for the $\sim 50$ Ma grains, whereas plutonic rocks in the Wenatchee and Chelan blocks, and the sheets in the Nason terrane and in the Holden unit, may be the source of the $\sim 90$ Ma grains (Table 3). The Middle Triassic to Late Jurassic grains of $\sim 150-240 \mathrm{Ma}$ can be attributed to contributions from a number of sources included in Table 4 and other ones to the west and east of the Straight Creek fault, such as the Early Jurassic Little Jack unit (Sauer et al., 2017), Late Jurassic detrital zircons of the Nanaimo Group (Mustard, 1994), Jurassic detrital zircons of the western mélange belt and the Northwest Cascades 
system to the southwest, and Late Jurassic rocks of the Methow basin to the northeast (Surpless et al., 2014; Sauer, 2017) (Figs. 2 and 43).

Detrital zircons $(\mathrm{n}=45)$ were dated from sample FS147, from the upper Swauk sandstone, north of the Tronsen Ridge Member (Fig. 30). This sample has age peaks at $\sim 64 \mathrm{Ma}, \sim 75 \mathrm{Ma}$, and $\sim 96 \mathrm{Ma}$, clusters at $\sim 128-147 \mathrm{Ma}$ and $\sim 197 \mathrm{Ma}$, one grain at $\sim 220$ Ma, one at $284 \mathrm{Ma}$, and two earliest Cambrian to Proterozoic grains at 540-580 Ma. The MDA is $75.8 \pm 2.0 \mathrm{Ma}$ (Fig. 44). Given the evidence for local derivation the MDA is probably significantly older than the actual depositional age.

The 64-75 Ma zircons have a probable Chelan block signature (Tables 3 and 4). The $\sim 95$ Ma grains are most likely derived from plutons in the Wenatchee block and from some plutons in the Chelan block (Table 3), whereas the smaller Early Cretaceous $\sim 128$ 147 Ma cluster could have various potential sources (Table 4), including the Okanogan Range batholith (Hurlow, 1993), Northwest Cascades System (Brandon et al., 1988), and Methow terrane (Surpless et al., 2014, 2017; Sauer, 2017). The 147-197 Ma cluster may have multiple sources listed in Table 4, including the Ingalls Ophiolite Complex (Miller, 1985), Nanaimo Group (Mustard, 1994; Matthews et al., 2017), western mélange belt (Tabor et al., 2002), and the Methow terrane (Surpless et al., 2014; Sauer, 2017). The $\sim 220$ Ma grain, has potential sources in the Cascade River Schist-Holden unit, Little Jack unit, and reworked zircons from sedimentary rocks in the Ingalls Complex (Figs. 2, 43 and 44; Table 4). The latter is compatible with field and petrographic evidence for an Ingalls source (Johnson and Miller, 1987; Harper et al., 2003) The few Paleozoic and Proterozoic ( $\sim 284-580 \mathrm{Ma})$ grains $(\mathrm{n}=3)$ are also compatible with the detrital zircons in 
the Lookout Mountain Formation south of the Swauk Formation (Brown and Gehrels, 2007; LaMaskin, 2012; MacDonald et al., 2017) (Fig. 43).

\section{Chumstick Formation}

Detrital zircons ( $\mathrm{n}=110)$ from sample FS253 from a sandstone interbed of the Devil's Gulch Member of the Chumstick Formation in the Beehive Reservoir area (Fig. 30) plot in a single cluster. They peak at $\sim 91.8 \mathrm{Ma}$, and have a MDA of $86.9 \pm 2.0 \mathrm{Ma}$ (Fig. 44).

Late Cretaceous ages are widespread in the Cascades core in the Wenatchee and Chelan blocks, and a 291 Ma pluton is a presumed source (Table 3). LA-ICP-MS U-Pb dating of zircons from Devil's Gulch conglomerate clasts by LaCasse et al. (2013) indicated ages of $91.0 \pm 2.3 \mathrm{Ma}, 90.6 \pm 1.5 \mathrm{Ma}$, and $91.7 \pm 1.8 \mathrm{Ma}$, which are consistent with crystallization ages of the Tenpeak pluton and Mount Stuart batholith in the Wenatchee block (Fig. 2). Considering the proximity of the Mount Stuart batholith to the Swauk Formation and that it is cut by the Leavenworth fault, it seems likely that the clasts were derived from this intrusion (Taylor et al., 1988; LaCasse et al., 2003).

\section{DISCUSSION}

The main focus of this research is to further understand the widely debated movement history of the Leavenworth fault. Different workers have interpreted the structure as either a dextral strike-slip fault or a reverse-slip fault. In addition, they have proposed contrasting ages of movement on the fault zone, and different hypotheses for the formation and depositional history of the Swauk basin (Taylor et al., 1988; Evans et al., 1989; Evans, 1994; Cheney and Hayman, 2009; Eddy et al., 2016). These interpretations are briefly reviewed before I discuss the implications of my data. 
Taylor et al. (1988) argued that alternating pulses of extensional and compressional deformation were the main controls of sedimentation of the Swauk Formation, a common occurrence in strike-slip basins. Evans (1994) suggested uplift along the fault zone due to transpression. Fold orientations, en enchelon faults, offset of conglomerate beds, and NEtrending dikes intruding the Swauk Formation are consistent with dextral shear (Evans, 1994). In contrast, Cheney and Hayman (2009) suggested that the Leavenworth fault zone is a post-depositional reverse fault. Most recently, geochronological data of Eddy et al. (2016) combined with paleocurrent data of Taylor et al. (1988) indicate that the Swauk basin accumulated along W- or SW-flowing streams between $\leq 59.9$ and $51.3 \mathrm{Ma}$, and along NE-flowing streams between 51.3 and $>49.9$ Ma. Tuff ages of 49.1 Ma in the lower part of the Chumstick Formation demonstrate that sediment accumulation initiated close in time to the eruption of the lower part of the Teanaway Formation (49.3 Ma) (Eddy et al., 2016), and support previous interpretations that the Chumstick Formation is younger than the Swauk Formation (e.g., Tabor et al., 1984). Eddy et al. (2016) argued that the rapid sediment accumulation rates in the Chumstick Formation are consistent with strikeslip basins, as are distinctive plutonic clasts separated dextrally from their likely sources.

\section{Summary and Analysis of Structural Data from the Swauk Formation}

The main strand of the Leavenworth fault in the study area has a NW strike of $\sim 320^{\circ}$ (Figs. 2 and 43). The fault zone is approximately $5 \mathrm{~km}$ wide in its southernmost segment, where this study was conducted. Overall, poles to beds $(\mathrm{n}=207)$ in the Swauk Formation indicate a WNW-striking and SSW-dipping maximum of $119^{\circ}, 61^{\circ} \mathrm{SSW}{ }^{\circ}$. Dips of Swauk beds range from $0^{\circ}-90^{\circ}$ to the NNE and SSW, and average $55^{\circ} \mathrm{SSW}$. Beds define 
a girdle and a fold axis plunging $4^{\circ}$ toward $297^{\circ}$ (Fig. 23). There is significant scatter in the girdle indicating non-cylindrical folding.

Most of the mapped folds $(\mathrm{n}=15)$ in the Swauk Formation trend NW to WNW, averaging $\sim 298$, and nearly $70 \%$ are counter-clockwise from the main strand of the Leavenworth fault. Of 15 measured folds, six trend between $0^{\circ}-10^{\circ}$ from the fault, two of which trend clockwise $\left(330^{\circ}\right.$ and $\left.340^{\circ}\right)$ to the fault, and four of which trend counterclockwise $\left(315-320^{\circ}\right)$ to the main fault. One fold trends between $11^{\circ}-20^{\circ}\left(300^{\circ}\right)$, two folds trend between $21^{\circ}-30^{\circ}\left(292^{\circ}\right.$ and $\left.296^{\circ}\right)$, and six folds trend $>30^{\circ}\left(249-290^{\circ}\right), 3$ of which trend $31^{\circ}-44^{\circ}\left(276^{\circ}-284^{\circ}\right)$ from the fault. In a dextral transpression wrench model, compressional features are oriented $<30^{\circ}$ counter-clockwise from the main fault, whereas in a dextral simple shear strike-slip model, they are oriented at $\sim 45^{\circ}$, and in a dextral transtension wrench model, they are oriented at $>45^{\circ}$ (Sanderson and Marchini, 1984). The seven folds that trend $<30^{\circ}$ counter-clockwise and the three folds that trend $31^{\circ}-45^{\circ}$ counter-clockwise from the main fault segment are compatible with a dextral transpression wrench model (Fig. 45). The folds that trend $>10^{\circ}$ from the main fault, are not compatible with a reverse fault, and only 6 folds oriented $0^{\circ}-10^{\circ}$ from the main fault are compatible with a reverse fault. Folds of the Swauk Formation in the study area mapped by Tabor et al. (1982) have a general NW trend, parallel to the main Leavenworth fault.

In the Ruby Creek-Windmill Point and Tip-Top areas of the Swauk Formation, where the most faults were measured, fault strikes were separated into those $>45^{\circ}, 31-44^{\circ}$, and 


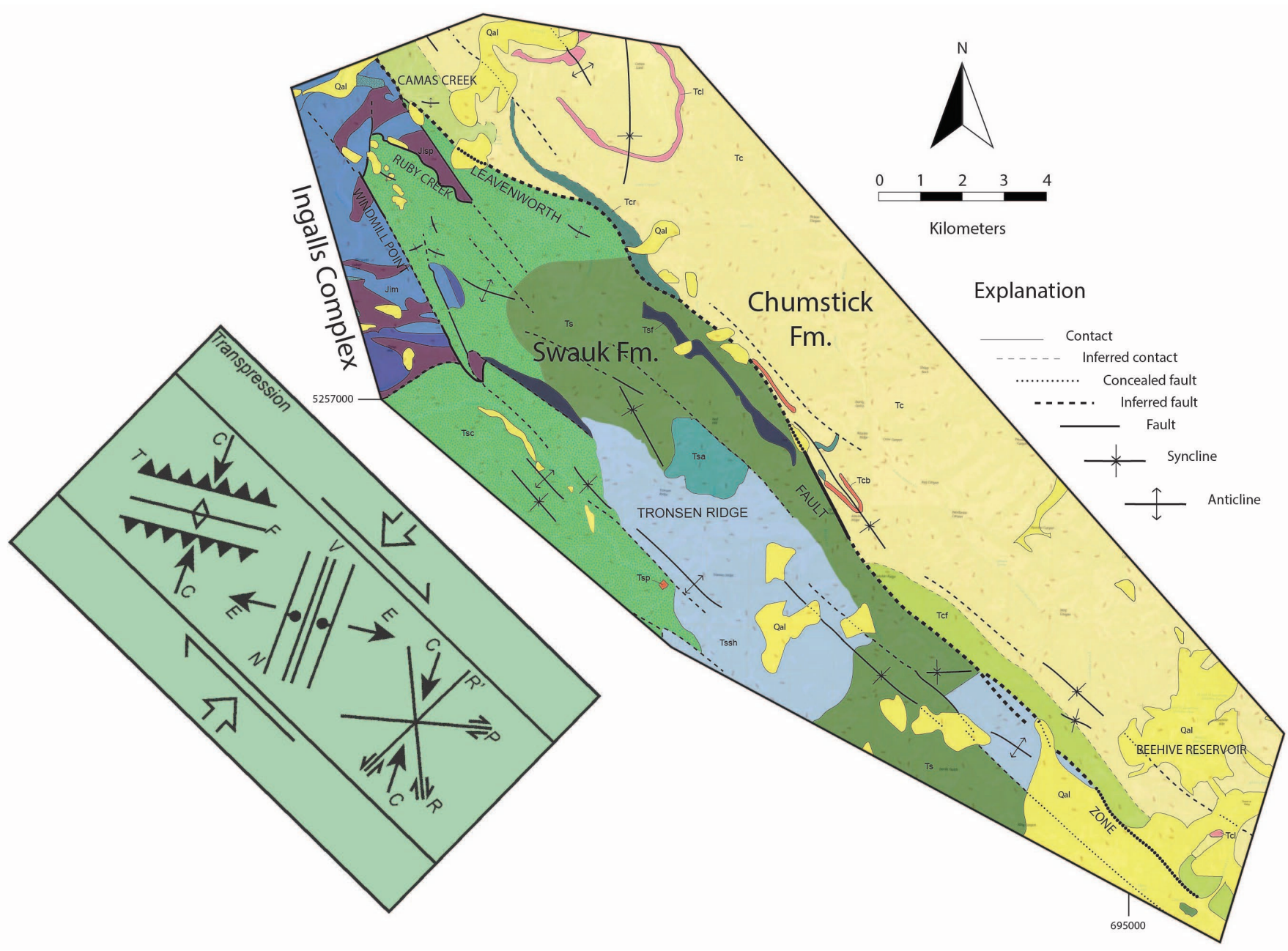

Figure 45. Geologic map of the study area highlighting folds. Diagram depicts secondary structures predicted for transpressional wrench fault systems. Diagram is oriented so that major fault is parallel to the Leavenworth fault zone. $\mathrm{C}=$ compression; $\mathrm{E}=$ extension; $\mathrm{F}=$ folds; $\mathrm{N}=$ normal faults; $\mathrm{P}=\mathrm{P}$-shears; $\mathrm{R}=$ Riedel shears; $\mathrm{R}$ ' = Riedel prime shears; $\mathrm{T}=$ thrust faults; $V=$ veins and dikes. Diagram modified from Sanderson and Marchini (1984). 
$<30^{\circ}$, clockwise and counter-clockwise to the main strand of the Leavenworth fault. Of $25 \mathrm{NW}$-striking faults, 19 faults strike $<30^{\circ}$ to the main Leavenworth fault, 11 of which strike parallel and counter-clockwise to the fault $\left(290^{\circ}-320^{\circ}\right)$, and 8 of which strike clockwise to the Leavenworth fault $\left(321^{\circ}-351^{\circ}\right)$. Six of the faults strike $31-44^{\circ}$ to the Leavenworth fault, 4 of which are clockwise $\left(333^{\circ}-003^{\circ}\right)$, and 2 of which are counterclockwise $\left(281^{\circ}-305^{\circ}\right)$. Nineteen out of $28 \mathrm{NE}$-striking faults strike $>45^{\circ}$ clockwise $\left(005^{\circ}-039^{\circ}\right)$ to the main Leavenworth fault, and nine faults strike $>45^{\circ}$ counter-clockwise $\left(054^{\circ}-082^{\circ}\right)$ to the fault. In a dextral transpression wrench model, normal faults are oriented $>60^{\circ}$, and thrust faults are oriented $<30^{\circ}$ from the main fault. In a dextral simple shear strike-slip model, both normal and thrust faults are oriented at $\sim 45^{\circ}$, and in a dextral transtension wrench model, normal faults are oriented $<30^{\circ}$, and thrust faults are oriented $>60^{\circ}$ from the main fault (Sanderson and Marchini, 1984). Due to a lack of exposure and kinematic indicators, the movement sense of these faults is unknown. If the faults that strike $<30^{\circ}$ counter-clockwise to the main fault are reverse, then these data could fit dextral transpression. In contrast, if the faults that strike $<30^{\circ}$ clockwise to the main fault are normal, then these data could fit dextral transtension (Fig. 46).

Of $22 \mathrm{NW}$-striking faults with measurable rakes in the Ruby Creek-Windmill Point and Tip-Top areas, 17 faults have rakes of $>45^{\circ}$ suggesting dip slip, and only 5 faults, which are not considered further, have rakes of $<30^{\circ}$ suggesting strike-slip movement. Nine of the 17 rakes that are $>45^{\circ}$ are on fault planes that strike clockwise to the Leavenworth fault and could be normal faults in dextral shear, and 8 are on fault planes that strike counter-clockwise to the Leavenworth fault and could be reverse faults in 


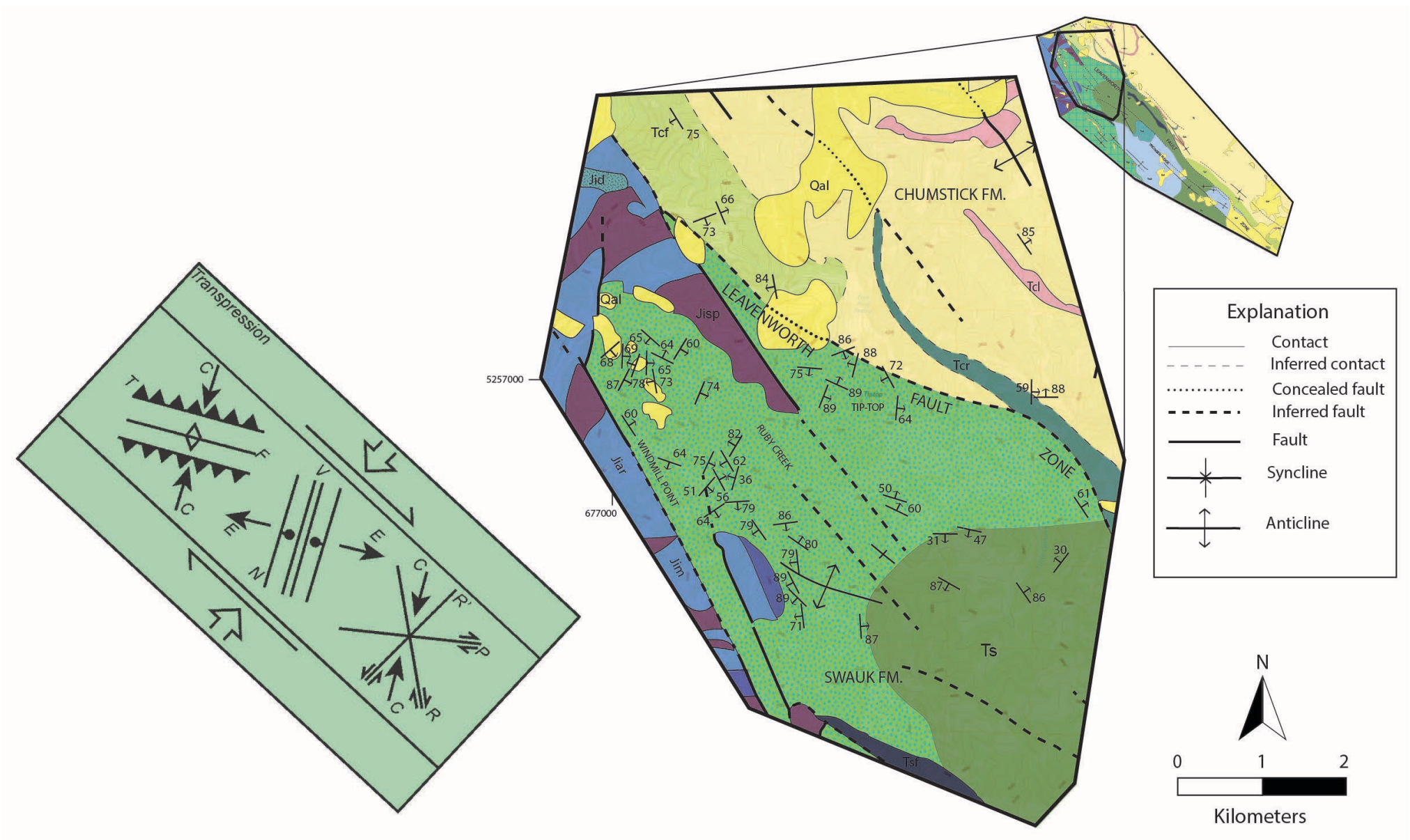

Figure 46. Geologic map of the Ruby Creek-Windmill Point and Tip-Top areas highlighting faults. Diagram depicts secondary structures predicted for transpressional wrench fault systems. Diagram is oriented so that the major fault is parallel to the Leavenworth fault zone. $\mathrm{C}=$ compression; $\mathrm{E}=$ extension; $\mathrm{F}=$ folds; $\mathrm{N}=$ normal faults; $\mathrm{P}=\mathrm{P}$-shears; $\mathrm{R}=\mathrm{R}$ iedel shears; $\mathrm{R}$ ' = Riedel prime shears; $\mathrm{T}=$ thrust faults; $\mathrm{V}=$ veins and dikes. Modified from Sanderson and Marchini (1984). 
dextral shear. Of $24 \mathrm{NE}$-striking faults with measurable rakes, 9 faults have rakes of $<30^{\circ}$, suggesting strike-slip movement, and are on fault planes that strike clockwise to the Leavenworth fault and could be R'-shears. Thirteen of the 24 faults have rakes of $>45^{\circ}$ suggesting dip slip, all of which are on fault planes that strike clockwise to the Leavenworth fault and could be normal faults in dextral shear. The remaining 2 faults have rakes between $31-44^{\circ}$, and are on fault planes that strike clockwise to the Leavenworth fault. These faults presumably have significant components of both strikeslip and dip-slip.

Gundersen's (2017) structural analysis of the eastern Swauk Formation, which she called domain 7 , extends from $\sim 6$ to $\sim 20 \mathrm{~km}$ southwest of my study area and does not include the Leavenworth fault zone. Her data were in large part based on the map of Tabor et al. (1982), and she noted that from south to north, folds mapped by Tabor et al. (1982) trend east-west and rotate to northwest-southeast approximately $12 \mathrm{~km}$ southwest of the Leavenworth fault, and continue this trend, as the fault zone is approached. Gundersen (2017) inferred that these folds, which as far as $\sim 18 \mathrm{~km} \mathrm{SW}$ from the Leavenworth fault, were rotated clockwise by dextral movement on the fault. Gundersen's (2017) interpretation of dextral shear generally agrees with my interpretation of dextral transpression.

Faults mapped by Tabor et al. (1982) strike $010^{\circ}-015^{\circ}$ and also fit a pure dextral strike-slip model if they are normal faults. Normal faults striking $50-55^{\circ}$ clockwise from the Leavenworth fault are compatible with dextral transpression. In contrast, if the system is transtensional, these faults may correspond to left-lateral R' shears (Fig. 46). It is 
plausible that these faults predate movement on the Leavenworth fault zone and are outside of the wrenching zone (Gundersen, 2017). This is in partial agreement with my data, in which faults strike mostly $>45^{\circ}$ and $<30^{\circ}$ from the Leavenworth fault, fitting a dextral transpression model or a dextral transtension model, depending on whether the movement along the faults is normal or reverse (Fig. 47).

\section{Summary and Analysis of Structural Data of the Teanaway Dikes}

Teanaway dikes rotate from NW-striking in the Ruby Creek-Windmill Point area, to NE-striking in the Tip-Top area, as the main strand of the Leavenworth fault is approached. This change implies that there is a rotation in the strain field related to the fault, or clockwise vertical axis rotation due to the fault.

Dikes in the SW part of the Ruby Creek-Windmill Point area strike perpendicular to the general strike of beds and trend of folds, whereas in the NE part of the Ruby Creek-Windmill Point area, dikes strike within $\sim 20^{\circ}$ of beds (Fig. 13). As the fault is approached, beds and dikes strike perpendicular to each other, suggesting a rotation in dike orientation, rather than in bedding.

Of the 19 measured dikes, seven dikes strike $>45^{\circ}$ clockwise $\left(006^{\circ}-045^{\circ}\right)$ to the main strand of the Leavenworth fault, and one dike strikes $>45^{\circ}$ counter-clockwise $\left(073^{\circ}\right)$ from the Leavenworth fault. Five dikes strike $22-40^{\circ}$ to the fault, four of which strike clockwise $\left(342^{\circ}-000^{\circ}\right)$ to the fault and one of which strikes counter-clockwise $\left(282^{\circ}\right)$ to the fault. Six dikes strike $<30^{\circ}$ to the fault, five of which strike clockwise $\left(329^{\circ}-346^{\circ}\right)$ and one of which strikes counter-clockwise $\left(316^{\circ}\right)$. In summary, most dikes strike $>45^{\circ}$ clockwise or $<30^{\circ}$ clockwise to the fault. This direction of extension could fit with the 


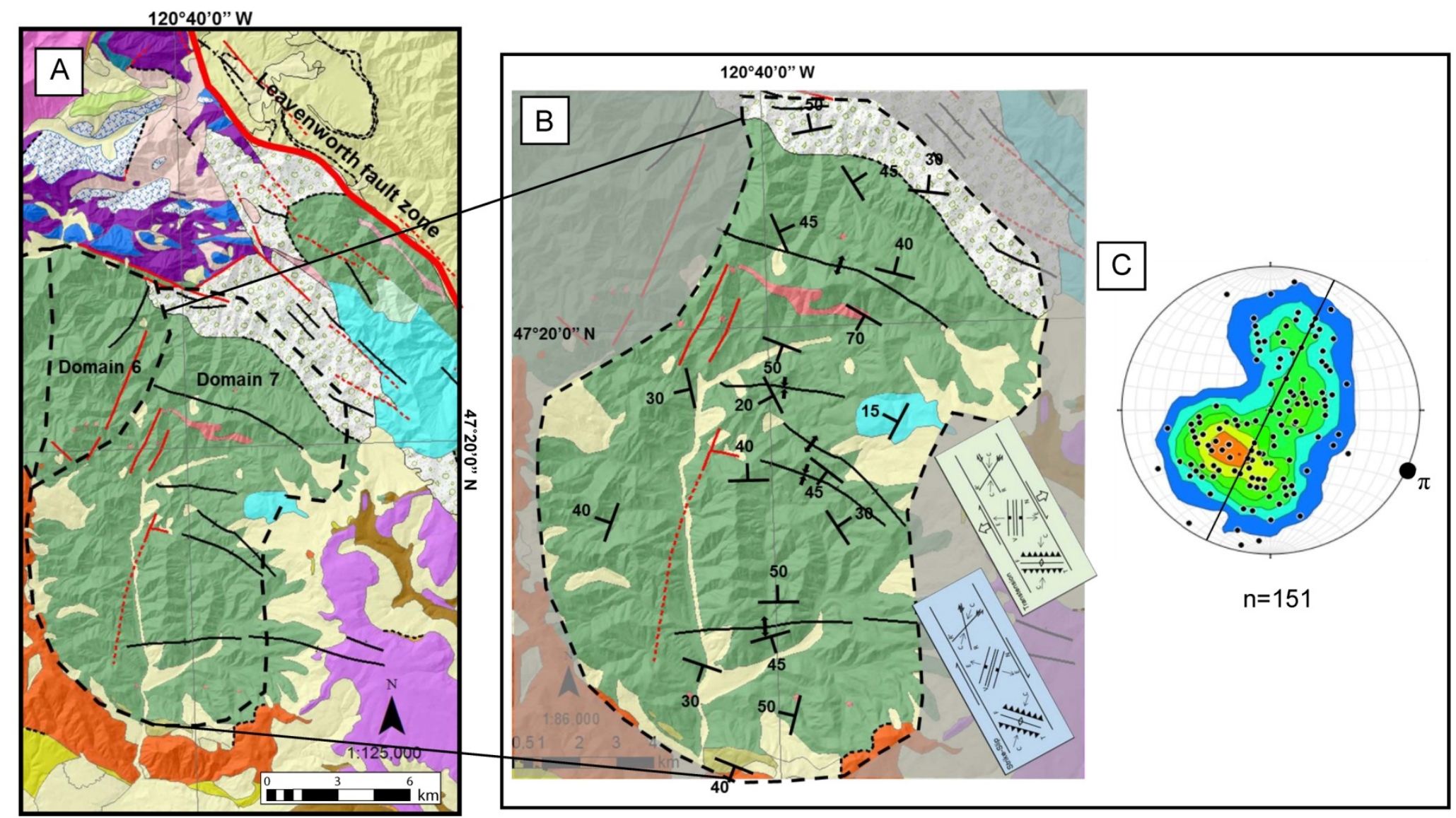

Figure 47. A) Geologic map of Gundersen's (2017) Domain 7 with respect to the study area and the Leavenworth fault zone. B) Geologic map highlighting the structures and bedding attitudes of Domain 7. Black lines are folds and red lines are faults. Synoptic diagrams modified from Sanderson and Marchini (1984) show secondary structures predicted for right-lateral strikeslip faults, which are oriented parallel to the Leavenworth fault zone (see caption for Fig. 46 for details). C) Stereographic projection showing poles to bedding with Kamb contouring (contour interval $=2$ sigma) and best fit great circle. $\mathrm{Pi}$-axis $=115^{\circ}$, $00^{\circ}$. Figure modified from Gundersen (2017). 
transpression model for the dikes that strike $>45^{\circ}$, or the transtension model for the eight clockwise dikes that strike $<30^{\circ}$ to the Leavenworth fault. A transtension model is more compatible with diking, but the potential rotation of dikes in the fault zone hampers interpretation.

Mendoza (2008) concluded that more than $85 \%$ of Teanaway dikes intruding the eastern part of Swauk Formation strike NE, with a mean strike of $040^{\circ} \mathrm{NE}$ and a dip of $78^{\circ} \mathrm{SE}$. Dike strikes and steep dips indicate sub-horizontal extension towards $\mathrm{N} 50^{\circ} \mathrm{W}$ $\mathrm{S} 50^{\circ} \mathrm{E}$, which is sub-parallel to slightly counter-clockwise of the regional strike. These data are broadly similar to those of Doran (2008) from the western and central parts of the Swauk basin, where the mean dike strike is $203^{\circ}$ and dip is $67 \mathrm{NW}^{\circ}$. Dikes show a systematic rotation of $13^{\circ}$ from west to east. Mendoza's (2008) and Doran's (2008) data are in agreement with the NE-striking dikes in my study, fitting a transtension model.

\section{Summary and Analysis of Structural Data from the Chumstick Formation}

The Chumstick Formation was studied in the Tip-Top, Mission Ridge, and Beehive Reservoir areas (Plate 1). In the Tip-Top and Beehive Reservoir areas, beds strike NW and dip predominantly NE (Figs. 7 and 25). On Mission Ridge, beds to the north strike NW and show a predominant SW dip, and over a distance of $\sim 5.6 \mathrm{~km}$ as the fault is approached, folds are indicated by the rotation of beds to WNW-striking (Fig. 21). These beds are oriented oblique to the main strand of the Leavenworth fault.

Overall, beds in the Chumstick Formation strike NW and dip mostly to the NE. There is significantly less folding and rotation of strikes in the Chumstick Formation compared to the Swauk Formation. Most folds are within $1 \mathrm{~km}$ of the main strand of the 
Leavenworth fault. Poles to beds in the Chumstick Formation form a bimodal distribution and define a weak girdle and a fold axis plunging $13^{\circ}$ towards $306^{\circ}$ (Fig. 29). Folds ( $\mathrm{n}=6$ ) of $\sim 200 \mathrm{~m}$ wavelength trend $\sim 270^{\circ}-360^{\circ}$; almost all $(\mathrm{n}=5)$ of these folds trend $\sim 270^{\circ}$ $330^{\circ}$, and the average is $\sim 312^{\circ}$. There are equal numbers of folds trending counterclockwise $\left(270^{\circ}-312^{\circ}\right)$ and clockwise $\left(325^{\circ}-360^{\circ}\right)$ to the main segment of the Leavenworth fault. These observations are in agreement with Tabor et al. (1982), who mapped NW-trending folds that trend clockwise and counter-clockwise to the main strand of the Leavenworth fault. The few fault planes $(\mathrm{n}=9)$ measured in the Tip-Top area of the Chumstick Formation strike mainly NW and dip steeply to the NE and SW. Two faults strike NE, at $>45^{\circ}$ clockwise $\left(52^{\circ}\right.$ and $\left.65^{\circ}\right)$ from the main strand of the Leavenworth fault. Five of the NW-striking faults are clockwise $\left(322^{\circ}-350^{\circ}\right)$ from the main fault, and 2 faults strike WNW $\left(280^{\circ}-296^{\circ}\right)$, counter-clockwise from the main fault. $\mathrm{NW}$-and NE-striking faults average $326^{\circ}$ and $076^{\circ}$, and dips average $59^{\circ} \mathrm{NE}$ and $77^{\circ} \mathrm{SE}$, respectively. In addition, rakes are mostly concentrated in the NW quadrant, are moderate to high, and average $61^{\circ}$. Five faults strike $<30^{\circ}$ clockwise from the main Leavenworth fault, compatible with a transpressional model if they were reverse faults, or a transtensional model if they were normal faults, whereas rakes suggest oblique slip with a component of dip slip (Fig. 26).

In the Tip-Top area, of $7 \mathrm{NW}$-striking fault planes, 5 have rakes of $>45^{\circ}$; only 2 have rakes of $<45^{\circ}$, and will not be considered further. Four of the 5 rakes that are $>^{\circ} 45$, are on fault planes that strike clockwise to the Leavenworth fault and could be normal faults, and 1 rake is on a fault plane that strikes counter-clockwise to the Leavenworth fault and 
could be a reverse fault. Two NE-striking fault planes have rakes of $<30^{\circ}$, and both are on fault planes that strike $>45^{\circ}$ clockwise to the Leavenworth fault and are most likely R' shears if related to the LF.

In the Beehive Reservoir area, fault strikes average $071^{\circ}$ and fault displacements measure $<3 \mathrm{~m}$. Fault planes without rakes strike NE and dip mostly to the NW, whereas fault planes with rakes show varying NW and SE dips. Of $5 \mathrm{NW}$-striking faults with measurable rakes, 4 have rakes of $>45^{\circ}, 3$ of which are on fault planes that strike counterclockwise to the Leavenworth fault and could be reverse faults, and 1 of which is on a fault plane that strikes clockwise to the Leavenworth fault and could be a normal fault. The 7 NE-striking fault planes with measurable rakes, strike $>60^{\circ}$ to the Leavenworth fault and are not compatible with a transpression or a transtension model. Overall, the rakes average $56^{\circ}$ (Fig. 28).

\section{Summary and Analysis of Structural Data from the Swauk and Chumstick}

\section{Formations}

In summary, fold trends in the Swauk and Chumstick formations are relatively consistent, trending mostly WNW to NW, and commonly $<30^{\circ}$ counter-clockwise to the main strand of the Leavenworth fault. Thus, these orientations are most compatible with a dextral transpressional wrench model. Folds are tighter in the Swauk Formation and bed strikes have a greater range than those in the Chumstick Formation, suggesting that there is more folding of the Swauk rocks, and that some folding near the Leavenworth fault predates folding of the Chumstick Formation.

Faults in the two formations have a similar strike and are oriented $>45^{\circ}$ or $<30^{\circ}$ 
clockwise and counter-clockwise to the main strand of the Leavenworth fault. In a transpression model, normal faults are oriented $>45^{\circ}$ clockwise to the main fault, and reverse faults are oriented $<30^{\circ}$ counter-clockwise to the main fault, whereas in a transtensional model, normal faults are oriented $<30^{\circ}$ clockwise to the main fault, and reverse faults are oriented $>45^{\circ}$ counter-clockwise to the main fault. Measured rakes for the small-scale faults suggest oblique slip with a higher component of dip-slip. However, because the sense of slip on the small faults is unknown, it is difficult to evaluate which model they fit best.

\section{Summary and Analysis of Petrography of the Swauk and Chumstick Formations}

The clastic samples collected in the Swauk and Chumstick formations are mostly fine-to coarse-grained sandstones. Most of them classify as lithic arkoses and feldspathic litharenites, and the modal data analyzed in this study plot mostly within the transitional continental, dissected arc, mixed, and quartzose recycled fields on a QFL diagram.

All Swauk samples consist dominantly of quartz, plagioclase, and micas. Approximate mineral mode averages are as follows: 49\% quartz, 24\% feldspars, and 5\% biotite. Rock fragments vary by sample and range as follows: $1-10 \%$ metamorphic, $0-7 \%$ mafic volcanic, $0-10 \%$ felsic volcanic, and 0-9\% sedimentary (mostly chert) rock.

Metamorphic clasts in the Swauk sandstones include micaceous quartzite, chloritemuscovite schist, graphitic biotite phyllite, graphitic schist, biotite schist, serpentinite, and quartz-muscovite-biotite schist. Mafic and felsic volcanic fragments, which are too fine-grained to further classify using a petrographic microscope, chert, and small quantities of diabase are also present. 
The two samples from the Chumstick Formation were collected from near the northern and southern ends of the Devil's Gulch Member. Approximate average mineral modes are: $57 \%$ quartz, $22 \%$ plagioclase, and $8 \%$ biotite. Sample FS13 from the northern Devil's Gulch Member is a siltstone, whereas sample FS253 (MDA $=86.9 \pm 2.0 \mathrm{Ma}$ ) from the southern Devil's Gulch Member in the Beehive Reservoir area is a conglomerate. The conglomerate contains dominantly tonalite clasts and small amounts of chert, felsic and mafic volcanic fragments, and phyllite.

Swauk sandstone samples in this study plot in the transitional continental, dissected arc, mixed, and quartzose recycled orogenic fields. According to Dickinson and Suzcek (1979), sandstones in the transitional continental block provenance are derived from fault-bounded basement blocks and are quartz rich due to multiple episodes of recycling and extensive transport. According to Maynard et al. (1982), sandstones derived from dissected arc provenances contain mixed plutonic and volcanic fragments, lesser amounts of metamorphic and sedimentary rock fragments, and abundant feldspars.

Taylor et al.’s (1988) sandstones of the conglomerate facies of Tronsen Creek, equivalent to my conglomerate facies (Plate 1), are medium-grained and arkosic, consisting predominantly of monocrystalline quartz, plagioclase, and lithic fragments. Tabor et al. (1987) reported QFL percentages of 38\%, 43\%, and 19\%, respectively, whereas my QFL percentages range between $40-76 \%, 16-34 \%$, and 8-28\%, indicating more quartz and less feldspar in the samples I analyzed from the conglomerate facies (Table 5). Tabor et al. (1987) also analyzed sandstones from the shale facies of Tronsen Ridge, which are fine-grained and arkosic, predominately consisting of monocrystalline 
Table 5. QFL percentages based on point counts for sandstone samples in the Swauk and Chumstick formations.

\begin{tabular}{|c|c|c|c|c|c|}
\hline \multirow{9}{*}{ Swauk } & Unit & Samples from this study & Q & $\mathrm{F}$ & $\mathrm{L}$ \\
\hline & Conglomerate facies & FS280 & 54 & 27 & 19 \\
\hline & $\begin{array}{l}\text { Micaceous feldspathic/ } \\
\text { lithofeldspathic sandstone }\end{array}$ & FS151 & 76 & 16 & 8 \\
\hline & $\begin{array}{l}\text { Micaceous feldspathic/ } \\
\text { lithofeldspathic sandstone }\end{array}$ & FS149 & 60 & 18 & 22 \\
\hline & $\begin{array}{l}\text { Micaceous feldspathic/ } \\
\text { lithofeldspathic sandstone }\end{array}$ & FS147 & 66 & 24 & 12 \\
\hline & Shale facies of Tronsen Ridge & FS140 & 46 & 29 & 25 \\
\hline & Shale facies of Tronsen Ridge & FS145 & 51 & 34 & 15 \\
\hline & Shale facies of Tronsen Ridge & FS224 & 40 & 31 & 28 \\
\hline & Shale facies of Tronsen Ridge & FS224A & 50 & 29 & 21 \\
\hline \multirow[t]{3}{*}{ Chumstick } & Conglomerate of Devil's Gulch & FS13 & 91 & 9 & 0 \\
\hline & Conglomerate of Devil's Gulch & FS253 & 41 & 43 & 16 \\
\hline & & Samples Tabor et al. (1987) & & & \\
\hline \multirow[t]{4}{*}{ Swauk } & Conglomerate of Tronsen Creek & $\mathrm{N} / \mathrm{A}$ & 38 & 43 & 19 \\
\hline & Shale facies of Tronsen Ridge & $\mathrm{N} / \mathrm{A}$ & 34 & 51 & 15 \\
\hline & Breccia faces of Devil's Gulch & $\mathrm{N} / \mathrm{A}$ & 30 & 69 & 1 \\
\hline & & Samples of Gundersen (2017) & & & \\
\hline Swauk & Conglomerate facies & MG-047 & 25 & 48 & 27 \\
\hline
\end{tabular}

Note: Q-F-Lt percentages were normalized to equal 100\%. Method of Folk (1974) was used in this study and the GazziDickinson method (Ingersoll et al., 1984) was used in Taylor et al.'s (1988) and Gundersen's (2017) study. 
quartz and plagioclase. Their QFL percentages for these sandstones are 34\%, 51\%, and $15 \%$, respectively, whereas my QFL percentages for the same sandstones range between $40-51 \%, 29-34 \%$, and $15-28 \%$, resulting in a greater amount of quartz and less feldspar than determined by Tabor et al. (1987) (Table 5).

Sandstone samples analyzed by Gundersen (2017) from across the Swauk basin (Fig. 48) consist of quartz, potassium feldspar, plagioclase, mica, and rock fragments. The most abundant lithic clasts are metamorphic, and include quartz- and mica-rich phyllite, schist, and gneiss. Other lithic fragments include siltstone, sandstone, chert, and volcanic rock. The sandstones plot predominately as arkoses and lithic arkoses. The QFL percentages for Gundersen's (2017) sample MG-047 (Fig. 47; Table 5), from the conglomerate facies of the Swauk Formation $\sim 5 \mathrm{~km}$ west of the study area, are $25 \%$, $48 \%$, and 27\%, respectively (Table 5). Gundersen (2017) documents an increase in modal percentages of biotite and plagioclase from west to east across the basin, in which biotite has percentages of up to $15 \%$. Gundersen's (2017) data are consistent with studies by Frizzell (1979) and Taylor et al. (1988), where sandstones plot within the dissected arc and continental-block provenance fields. In contrast, my sandstones mostly plot in the transitional continental, dissected arc, mixed, and quartzose recycled orogenic fields, and the biotite modal percentages only reach $8 \%$, plagioclase percentages reach $32 \%$, and quartz percentages reach 68\% (Appendix B). Some of the sandstones analyzed in this study were collected from strata that may be stratigraphically higher than sandstones analyzed by Tabor et al. (1987) and Gundersen (2017). This change in mineral modes, from less quartz-rich sandstones in the lower Swauk Formation to more quartz-rich 


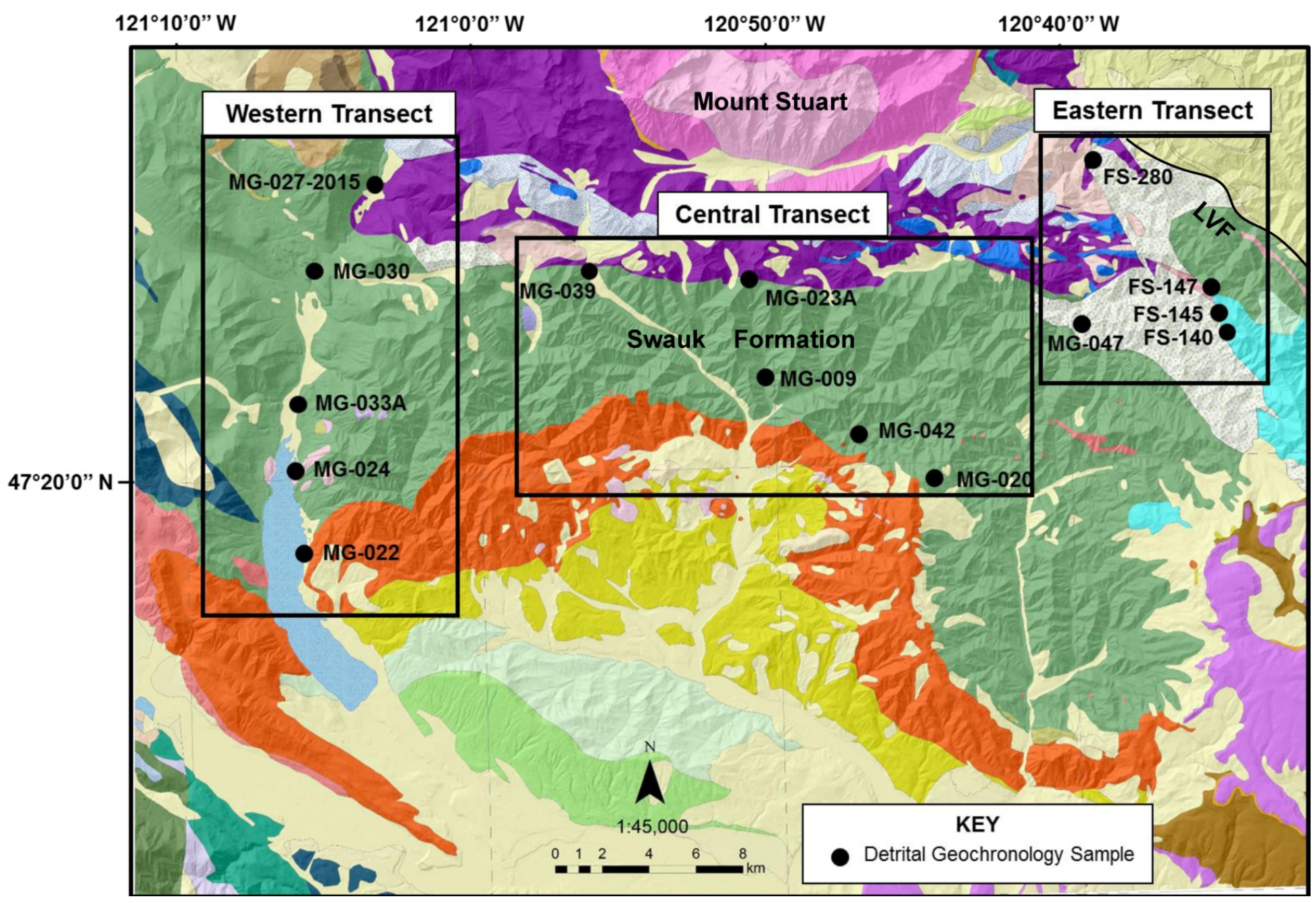

Figure 48. Geologic map showing detrital zircon sample locations in western, central, and eastern transects of Gundersen (2017) and this study. Gundersen's (2017) samples are labeled MG and this studies' samples are labeled FS. LVF Leavenworth fault zone. Figure modified from Gundersen (2017). 
sandstones in the upper Swauk Formation, may suggest a change of source.

Tabor et al.'s (1987) sample from the breccia facies of Devil's Gulch (Tsd), equivalent to my conglomerate (Tcf) of the Chumstick Formation (Plate 1), has QFL modal percentages of $30 \%, 69 \%$, and $1 \%$, respectively, whereas my modal percentages are $41 \%, 43 \%$, and $16 \%$ (Table 5). Tabor et al.'s (1987) and my data are different, however, the modes for feldspars are both the highest, followed by quartz, and lithics. These differences may reflect variations in grain size in the local source for these sediments, which were likely only transported a short distance (Cashman and Whetten, 1974).

\section{Geochronology and Provenance of Units}

The detrital mineralogy analysis of the Swauk and Chumstick Formation samples suggests that sediment was derived from plutonic and metamorphic sources (Fraser, 1985; Taylor et al., 1988). In addition, the geochronological data from this study coupled with Eddy et al.'s (2016) data, strongly imply that the Swauk Formation detritus in this study has a local provenance, and that sediment was transported by paleocurrents draining into the basins from the north and northeast between $\leq 59.9$ and $\sim 51.3 \mathrm{Ma}$, and from the southwest between $\sim 51.3$ and 49.9 Ma (Frizzell, 1979; Tabor et al., 1984; Fraser, 1985; Taylor et al., 1988; Evans, 1994; Eddy et al., 2016).

Potential sources north and northeast of the Swauk Formation are 96-86 Ma and 9665 Ma plutons of the Wenatchee and Chelan blocks of the Cascades crystalline core, respectively (Fig. 2; Table 3) (Tabor et al., 1989; Miller et al., 2009a). These plutons intrude host rocks of the Early Cretaceous Chiwaukum Schist of the Nason terrane, 
Jurassic Ingalls Ophiolite, Cretaceous Swakane Biotite Gneiss, Paleozoic to Jurassic Napeequa unit, and the Triassic and Late Cretaceous Cascade River Schist-Holden unit (Miller, 1985; Tabor et al., 1989, 2003; Miller et al., 1994, 2009a; Gordon et al., 2017), which are also potential sources for detritus (Figs. 2 and 43; Table 4). Other potential sources farther to the north include the 120-110 Ma Okanogan Range batholith (Hurlow, 1993), and the Methow terrane (DeGraaff-Surpless et al., 2003; Surpless et al., 2014; Gordon et al., 2017; Sauer et al., 2017). Likely sources of west-and southwest-derived detritus include the Nanaimo Group (Mustard, 1994), western mélange belt, and NW Cascades system (Fig. 43).

Sample FS280 (MDA of 67.2 $\pm 1.9 \mathrm{Ma}$ ) from the Ruby Creek-Windmill Point area (Figs. 30 and 44) consists primarily of detrital zircons that may be derived from a combination of the Wenatchee and Chelan blocks, in particular alluvial fan deposits from the Ingalls ophiolite complex. These deposits likely reflect early motion on the Leavenworth fault (Johnson and Miller, 1987) and indicate a local southwest source.

Sample FS147 (MDA of $75.8 \pm 2.0 \mathrm{Ma}$ ) from north of the Tronsen Ridge Member (Figs. 30 and 44) consists of detrital zircons from a combination of sources, such as the Wenatchee and Chelan blocks, sources to the north including the Methow terrane and Okanogan Range batholith, to the west including the Nanaimo Group, and to the southwest including the Lookout Mountain Formation.

Sample FS140 (MDA of 51.6 $\pm 1.3 \mathrm{Ma}$ ) from the lower Tronsen Ridge Member (Figs. 30 and 44) consists primarily of $\sim 70-90$ Ma detrital zircons that may have been derived from the Chelan and Wenatchee blocks. This sample has a $\sim 50$ Ma peak, which 
probably reflects a Silver Pass tuff source. These sources and the MDA are in accordance with east and southwest-directed paleocurrents.

Sample FS145 (MDA of $50.46 \pm 0.17 \mathrm{Ma}$ ) (M. Eddy, written communication) from the upper Tronsen Ridge Member (Figs. 30 and 44) consists of detrital zircons that were perhaps derived from a combination of sources, including: the $~ 51.3$ Ma Silver Pass tuff; the Chelan and Wenatchee blocks to the north and northeast, the Nanaimo Group to the west, and the western mélange belt to the southwest. The changes inferred in paleoflow from the SW at $\sim 51.3-49.9 \mathrm{Ma}$, and the MDA of $50.46 \pm 0.17 \mathrm{Ma}$, indicate that the most probable source is the Nanaimo Group or the western mélange belt.

Detrital zircon geochronology by Gundersen (2017) in the Swauk Formation and the geochronology conducted in this study show a similar age trend (Fig. 49). Relative probability plots of detrital zircon ages in the Swauk Formation display an increase in older grains moving up section. The dominant age peaks in the lower Swauk Formation cluster around $\sim 80-65 \mathrm{Ma}$, whereas farther up section, the $\sim 70-60$ Ma peaks decrease and the dominant peaks are $\sim 100-90$ Ma. This pattern could be due to the gradual exhumation of the nearby Mount Stuart batholith and host rocks of the Wenatchee block at ca. $55 \mathrm{Ma}$, thus adding to the Swauk detritus from the Chelan block.

Detrital zircons for sample FS253 (MDA of $86.9 \pm 2.0 \mathrm{Ma}$ ), from the sandstone of the Devil's Gulch Member of the Chumstick Formation in the Beehive Reservoir area, have a similar age to that of Mount Stuart batholith. The large tonalitic clasts in the conglomerate, which coupled with the MDA, suggest that the main source of the clasts in the Devil's Gulch Member is the Mount Stuart batholith. The size of these clasts implies 

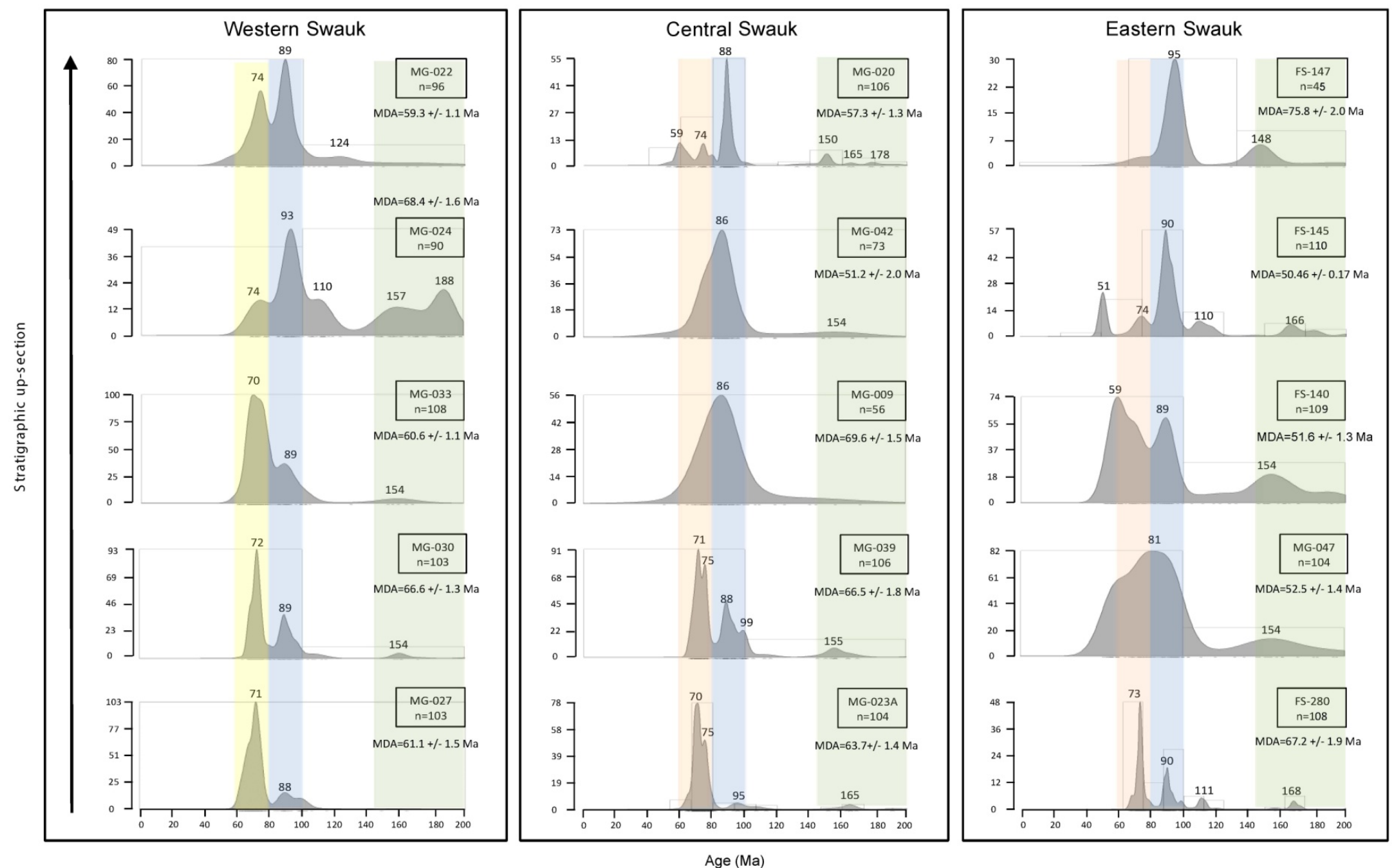

Figure 49. Kernal density plots of detrital zircon ages from 0-200 Ma in the western, central, and eastern transects through the Swauk Formation. Combined data from Gundersen (2017) and this study. Figure modified from Gundersen (2017). 
that they did not travel far, and their location 20-30 km to the SE of the Mount Stuart batholith (Fig. 2), suggests dextral offset of this magnitude along the Leavenworth fault.

\section{CONCLUSIONS}

The fold $(\pi)$ axes defined by all beds in the Swauk Formation and Chumstick Formation are $297^{\circ}, 4^{\circ}$ and $306^{\circ}, 13^{\circ}$, respectively, which are orientations expected for dextral transpression related to the LFZ. Smaller folds are somewhat variable in orientation, which for the Swauk Formation probably reflects the earlier folding inferred to result from the collision of Siletzia.

Approximately $40 \%$ of the folds in the Swauk and Chumstick formations trend $<30^{\circ}$ counter-clockwise from the main strand of the Leavenworth fault, and another $22 \%$ trend $31-44^{\circ}$ counter-clockwise from the fault, compatible with dextral transpression. Nineteen percent of the folds trend $<30^{\circ}$ clockwise from the main strand of the Leavenworth fault, and another $19 \%$ of the folds trend $>45^{\circ}$ clockwise from the fault. These orientations are not compatible with a dextral wrench model.

Line-length balancing of folded beds, assuming flexural slip, yields $\sim 0.6-1.1 \mathrm{~km}$ of shortening in the Ruby Creek-Windmill Point area and $\sim 1.7-2.2 \mathrm{~km}$ of shortening in the Tronsen Ridge area. Folds in the Swauk Formation are tighter and more common than in the Chumstick Formation and in the Teanaway Formation, which unconformably overlies the Swauk Formation. Thus, early folding of the Swauk Formation occurred between the youngest MDA of a Swauk sandstone at $50.46 \pm 1.7$ and the oldest tuff date in the lower part of the Chumstick Formation at $49.147 \pm 0.041$ Ma. Movement on an early strand of the Leavenworth fault may have been responsible for the alluvial fan deposits containing 
abundant clasts from the Ingalls Ophiolite in the Swauk Formation in the northern Ruby Creek area.

The time constraints of folding in the Swauk Formation also give insight into the timing of the collision of the Siletzia oceanic plateau with the Pacific Northwest margin. The accretion of Siletzia generated a shift in tectonics to transtension and right-lateral, strike-slip on the Leavenworth and the Straight Creek faults. The switch to transtension facilitated the intrusion of the Teanaway dikes at $49.3 \mathrm{Ma}$, and the rapid rates of subsidence and deposition of the Chumstick Formation in what has been interpreted as a strike-slip basin. Subsequent transpression on the Leavenworth fault led to further folding of the Swauk Formation and Chumstick Formation.

Faults in the Swauk and Chumstick formations strike $>45^{\circ}$ clockwise, or $<30^{\circ}$ counter-clockwise, from the main strand of the Leavenworth fault. The slip along these faults is unknown and thus, it is difficult to evaluate them in a kinematic model. However, slickenside striations on fault planes range from shallow to steep, and most slickensides in the study area rake $>45^{\circ}$. Assuming normal slip on the faults that are $>45^{\circ}$ clockwise to the Leavenworth fault, and have rakes of $>45^{\circ}$, then this orientation fits dextral transpression. Teanaway dikes rotate from NW- to NE-striking as the main Leavenworth fault is approached, implying that there is a rotation in the strain field, most likely related to the fault.

Petrographic studies and detrital zircon geochronology suggest that sediment in the Swauk Formation is locally derived from sources to the north, northwest, northeast, and southwest, such as the 96-86 Ma and 96-45 Ma plutons of the Wenatchee and Chelan 
blocks, respectively, the western mélange belt, the Northwest Cascades system, and the Nanaimo Group. Detrital zircon MDAs in the Swauk Formation range from $67.2 \pm 1.9$ to $50.46 \pm 0.17 \mathrm{Ma}$, and support interpretations that Swauk deposition ended before deposition of the Chumstick Formation at $\sim 49.147 \pm 0.041$ Ma.

The tonalitic composition of the large clasts in the breccia facies of the Devil's Gulch of the Chumstick Formation, coupled with the MDA of $\sim 86.9 \pm 2.0 \mathrm{Ma}$ and an age peak of 91.8 Ma, suggest that these clasts were likely derived from the Mount Stuart batholith, and support evidence for 20-30 km of dextral displacement along the Leavenworth fault. Collectively, the data presented in this study indicate that folding near the Leavenworth fault zone better fits a dextral transpressional wrench model than a reverse fault model. 


\section{REFERENCES CITED}

Allmendinger, R.W., 2017, Stereonet 9, A computer program for stereographic projections, Department of Geology, Cornell University, http://www.geo.cornell.edu/geology/faculty/RWA/programs/stereonet.html.

Barksdale, J.D., 1975, Geology of the Methow Valley, Okanogan County, Washington: State of Washington, Department of Natural Resources, Division of Geology and Earth Resources, v. 68, 72 p.

Brandon, M.T., Cowan, D.S., and Vance, J.A., 1988, The Late Cretaceous San Juan Thrust System, San Juan Islands, Washington: Geological Society of America Special Paper 221, 81 p., doi:10.1130/SPE221-p1.

Brown, E.H., and Gehrels, G.E., 2007, Detrital zircon constraints on terrane ages and affinities and timing of orogenic events in the San Juan Islands and North Cascades, Washington: Canadian Journal of Earth Sciences, v. 44, p. 1375-1396, doi: 10.1139/E07-040.

Brown, E.H., Carey, J.A., Dougan, B.E., Dragovich, J.D., Fluke, S.M., and McShane, D.P., 1994, Tectonic evolution of the Cascades crystalline core in the Cascade River area, Washington: Washington Division of Geology and Earth Resources Bulletin, v. 80, p. 93-113.

Cashman, S.M., and Whetten, J.T., 1974, Low-temperature serpentinization of peridotite fanglomerate on the west margin of the Chiwaukum graben, Washington: Geological Society of America Bulletin, v. 87, p. 1773-1776.

Cater, F.W., 1982, Intrusive Rocks of the Holden and Lucerne Quadrangles, Washington: The relation of depth zones, composition, textures, and emplacement of plutons: U.S. Geological Survey Professional Paper 1220, 108 p.

Cater, F.W., and Crowder, D.F., 1967, Geologic map of the Holden quadrangle, Snohomish and Chelan Counties, Washington: U.S. Geological Survey Geologic Quadrangle Map GQ-646, scale 1:62,500.

Cheney, E.S., and Hayman, N.W., 2009, The Chiwaukum structural low: Cenozoic shortening of the central Cascade Range, Washington State, USA: Geological Society of America Bulletin, v. 121, p. 1135-1153, doi: 10.1130/B26446.1.

Clayton, D.N., 1973, Volcanic history of the Teanaway basalt, east-central Cascade Mountains, Washington [M.S. thesis]: Seattle, University of Washington, 55 p.

DeGraaff-Surpless, K., Mahoney, J.B., Wooden, J.L., and McWilliams, M.O., 2003, Lithofacies control in detrital zircon provenance studies: Insights from the 
Cretaceous Methow basin, southern Canadian Cordillera: Geological Society of America Bulletin, v. 115, p. 899-915, doi:10.1130/B25267.1.

Dickinson, W.R., and Gehrels, G.E., 2009, Use of U-Pb ages of detrital zircons to infer maximum depositional ages of strata: A test against a Colorado Plateau Mesozoic database: Earth and Planetary Science Letters, v. 288, p. 115-125.

Dickinson, W.R. and Suczek, C.A., 1979, Plate tectonics and sandstone compositions: American Association of Petroleum Geologists Bulletin, v. 63, p.2164-2182.

Dickinson, W.R., Beard, S., Brakenbridge, F., Erjavec, J., Ferguson, R., Inman, K., Knepp, R., Lindberg, P., Ryberg, P., 1983, Provenance of North American Phanerozoic sandstones in relation to tectonic setting: Geological Society of America Bulletin, v. 64, p. 233-235.

Donaghy, E.E., 2015, Structure, stratigraphy, and provenance of Eocene sedimentary rocks in the Chumstick basin, central Washington [M.S. Thesis]: Northern Arizona University, Flagstaff, Arizona, 252 p.

Doran, B.A., 2009, Structure of the Swauk Formation and Teanaway dike swarm, Washington Cascades [M.S. Thesis]: San Jose, California, San Jose State University, $97 \mathrm{p}$.

Eddy, M.P., Bowring, S.A, Umhoefer, P.J., Miller, R.B., McLean, N.M., and Donaghy, E.E., 2016, High-resolution temporal and stratigraphic record of Siletzia's accretion and triple junction migration from nonmarine sedimentary basins in central and western Washington: Geological Society of America Bulletin, v. 128, p. 425-441, doi: 10.1130/B31335.1.

Evans, J.E., 1988, Depositional environments, basin evolution and tectonic significance of the Eocene Chumstick Formation, Cascade Range, Washington [PhD thesis]: Seattle, University of Washington, $325 \mathrm{p}$.

Evans, J.E., 1994, Depositional history of the Eocene Chumstick Formation: Implications of tectonic partitioning for the history of the Leavenworth and Entiat-Eagle Creek fault system, Washington: Tectonics, v. 13, p. 1425-1444, doi: 10.1029/94TC01321.

Evans, J.E., and Johnson, S.Y., 1989, A field guide to the Paleogene strike-slip basins of central Washington; Swauk Formation and Chumstick Formation, in Joseph, N.L., et al., eds., Geologic Guidebook for Washington and Adjacent Areas: Washington Division of Geology and Earth Resources, p. 1425-1444. 
Folk, R.L., 1974, Petrology of Sedimentary Rocks: Austin, Texas—, Hemphill Press, second edition, $182 \mathrm{p}$.

Foster, R.J., 1958, The Teanaway dike swarm of Central Washington: American Journal of Science, v. 256, p. 644-653.

Fraser, G.T., 1985, Straigraphy, sedimentology, and structure of the Swauk Formation in the Swauk Pass area, central Cascades, Washington [M.S. thesis]: Pullman, Washington State University, 219 p.

Frizzell, V.A., Jr., 1979, Petrology and stratigraphy of Paleogene nonmarine sandstones, Cascade Range, Washington: U.S: Geological Survey Open-File Report 79-1149, $151 \mathrm{p}$.

Gordon, S.M., Miller, R.B., and Sauer, K.B., 2017, Incorporation of sedimentary rocks into the deep levels of continental magmatic arcs: Links between the North Cascades arc and surrounding sedimentary terranes, in Haugerud, R.A., and Kelsey, H.M., eds., From the Puget Lowland to East of the Cascade Range: Geologic Excursions in the Pacific Northwest: Geological Society of America Field Guide 49, p. 101-141, doi:10.1130/2017.0049 (06).

Gresens, R.L., 1982, Early Cenozoic geology of central Washington State: II. Implications for plate tectonics and alternatives for the origin of the Chiwaukum graben: Northwest Science, v. 56, p. 259-264.

Gresens, R.L., Naeser, C.W., and Whetten, J.W., 1981, Stratigraphy and age of the Chumstick and Wenatchee formations: Tertiary fluvial and lacustrine rocks, Chiwaukum graben, Washington: Geological Society of America Bulletin, v. 92, p. 223-236.

Gundersen, M., 2017, A record of the evolving Eocene tectonics of the Pacific Northwest in the Swauk Formation, Central Washington [M.S. thesis]: Flagstaff, Arizona, Northern Arizona University, 216 p.

Harper, G.D., Miller, R.B., MacDonald, J.H., Jr., Miller, J.S., and Mlinarevic, A.N., 2003, Evolution of a polygenetic ophiolite: The Jurassic Ingalls ophiolite, Washington Cascades, in Swanson, T.W., ed., Western Cordillera and Adjacent Areas: Boulder, Colorado, Geological Society of America, Field Guide 4, p. 251265.

Haugerud, R.A., van der Heyden, P., Tabor, R.W., Stacey, J.S., and Zartman, R.E., 1991, Late Cretaceous and early Tertiary plutonism and deformation in the Skagit Gneiss Complex, North Cascade Range, Washington and British Columbia: Geological Society of America Bulletin, v. 103, p. 1297-1307. 
Hurlow, H.A., 1992, Structural and U/Pb geochronologic studies of the Pasayten fault, Okanogan Range batholith, and southeastern Cascades crystalline core, Washington [Ph.D. thesis]: Seattle, University of Washington, 180 p.

Hurlow, H.A., 1993, Mid-Cretaceous strike-slip and contractional fault zones in the western intermontane terrane, Washington, and their relation to the North Cascades-southeastern Coast Belt orogen: Tectonics, v. 12, p. 1240-1257, doi:10.1029/93TC01061.

Ingersoll, R.V., Bullard, T.F., Ford, R.L., Grimm, J.P., Pickle, J.D. and Sares, S.W., 1984, The effect of grain size on detrital modes: a test of the Gazzi-Dickinson point-counting method: Journal of Sedimentary Research, v. 54, p.103-116.

Johnson, S.Y., 1984, Evidence for margin-truncating transcurrent fault (pre-late Eocene) in western Washington: Geology, v. 12, p. 538-541.

Johnson, S.Y., and Miller, R.B., 1987, Ingalls Tectonic Complex and Swauk Formation, Ruby Creek area, Cascade Mountains, Washington, in Hill, M.L., ed., Cordilleran Section of the Geological Society of America: Geological Society of America Centennial Field Guide 1, p. 363-368.

LaCasse, T.J., 2013, Using a coarse-grained conglomerate to investigate lateral offset along the Leavenworth Fault Zone, North Cascades, Washington [Senior Integrative Exercise]: Northfield, Minnesota, Carleton College, 40 p.

LaMaskin, T.A., 2012, Detrital zircon facies of Cordilleran terranes in western North America: GSA Today, v. 22, no.3, p. 4-11, doi:10.1130/GSATG142A.1.

MacDonald, J.H., Jr., Harper, G.D., Miller, R.B., Miller, J.S., Mlinarevic, A.N., and Schultz, C.E., 2008, The Ingalls ophiolite complex, central Cascades, Washington, in Wright, J.E., and Shervais, J,W, eds., Geochemistry, tectonic setting, and regional correlations, Ophiolites, Arcs, and Batholiths: A Tribute to Cliff Hopson: Geological Society of America Special Paper, v. 438, p. 133-159.

MacDonald, J.H., and Schoonmaker, A., 2017, Evidence of a Late Jurassic ridge subduction event: Geochemistry and age of the Quartz Mountain stock, Manastash inlier, Central Cascades, Washington: The Journal of Geology, v. 125, p. 423-438, doi: 10.1086/692099.

Matthews, W.A., Guest, B., Coutts, D., Bain, H., and Hubbard, S., 2017, Detrital zircons from the Nanaimo basin, Vancouver Island, British Columbia: An independent test of Late Cretaceous to Cenozoic northward translation: Tectonics, v. 36, p. 854-876, doi:10.1002/2017TC004531. 
Matzel, J.E., Bowring, S.A., and Miller, R.B., 2004, Protolith age of the Swakane Gneiss, North Cascades, Washington: evidence of rapid underthrusting of sediments beneath an arc: Tectonics, v. 23, p. 1-18.

Matzel, J.P., Bowring, S.A., and Miller, R.B., 2006, Time scales of pluton construction at differing crustal levels: Examples from the Mount Stuart and Tenpeak intrusions, North Cascades, Washington: Geological Society of America Bulletin, v. 118, p.1412-1430, doi: 10.1130/B25923.1.

Maynard, J.B., Valloni, R. and Yu, H.S., 1982, Composition of modern deep-sea sands from arc-related basins: Geological Society, London, Special Publications, v.10, p. 551-561.

Mendoza, M.K., 2008, Tectonic implications of the Eocene Teanaway dike swarm in the eastern Swauk basin, central Washington: Geological Society of America Abstracts with Programs, v. 40, no. 1, p. 66.

Metzger, E.P., Miller, R.B., and Harper, G.D., 2002, Geochemistry and tectonic setting of the ophiolitic Ingalls complex, North Cascades, Washington; implications for correlations of Jurassic Cordilleran ophiolites: The Journal of Geology, v. 110, p. 543-560, doi: 10.1086/341759.

Miller, R.B., 1985, The ophiolitic Ingalls Complex, north-central Cascade Mountains, Washington: Geological Society of America Bulletin, v. 96, p. 27-42, doi: 10.1130/0016-7606.

Miller, R.B., 1994, A mid-crustal contractional stepover zone in a major strike-slip system, North Cascades, Washington: Journal of Structural Geology, v. 16, p. 4760 .

Miller, R.B., and Bowring, S.A., 1990, Structure and chronology of the Oval Peak batholith and adjacent rocks: Implications for the Ross Lake fault zone, North Cascades, Washington: Geological Society of America Bulletin, v. 102, p. 13611377, doi: 10.1130/0016 7606(1990)102<1361:SACOTO>2.3.CO;2.

Miller, R.B., and Paterson, S.R., 1994, The transition from magmatic to high temperature solid-state deformation: Implications from the Mount Stuart batholith, Washington: Journal of Structural Geology, v. 16, p. 853-865, doi: 10.1016/01918141(94)90150-3.

Miller, R.B., Gordon, S.M., Bowring, S.A., Doran, B.A., McLean, N.M., Michels, Z.D., Shea, E.K., Whitney, D.L., Wintzer, N.E., and Mendoza, M.K., 2009a, Linking deep and shallow crustal processes in an exhumed continental arc, North Cascades, Washington, in O’Connor, J.E., Dorsey, R.J., and Madin, I.P., eds., 
Volcanoes to Vineyards: Geologic Field Trips through the Dynamic Landscape of the Pacific Northwest: Geological Society of America Field Guide 15, p. 373406, doi: 10.1130/2009.fld015(19).

Miller, R.B., Paterson, S.R., and Matzel, J.P., 2009b, Plutonism at different crustal levels: Insights into the $\sim 5-40 \mathrm{~km}$ (paleodepth) North Cascades crustal section, Washington, in Miller, R.B., and Snoke, A.W., eds., Crustal Cross Sections from the Western North America Cordillera and Elsewhere: Implications for Tectonic and Petrologic Processes: Geological Society of America Special Paper 456, p. 125-149, doi: 10.1130/2009.2456(05).

Miller, R.B., Gordon, S.M., Bowring, S.A., Doran, B.A., McLean, N.M., Michels, Z.D., Shea, E.K., and Whitney, D.L., 2016, Linking deep and shallow crustal processes during regional transtension in an exhumed continental arc, North Cascades, northwestern Cordillera (USA): Geosphere, v. 12, no. 3, p. 900-924, doi: 10.1130/GES01262.1.

Misch, P., 1966, Tectonic evolution of the northern Cascades of Washington State-a west Cordilleran case history: Canadian Institute of Mining and Metallurgy, Special v. 8, p. 101-148.

Mustard, P.S., 1994, The Upper Cretaceous Nanaimo Group, Georgia Basin, in Monger, J.W.H., ed., Geology and Geological Hazards of the Vancouver Region, Southwestern British Columbia: Geological Society of Canada Bulletin 481, p. 27-95, doi:10.4095/203246.

Sanderson, D.J. and Marchini, W.R.D., 1984, Transpression: Journal of Structural Geology, v. 6, p. 449-458.

Sauer, K.B., Gordon, S.M., Miller, R.B., Vervoort, J.D., and Fisher, C.M., 2017, Evolution of the Jura-Cretaceous North American Cordilleran margin: Insights from detrital-zircon $\mathrm{U}-\mathrm{Pb}$ and $\mathrm{Hf}$ isotopes of sedimentary units of the North Cascades Range, Washington: Geosphere, v. 13, no. 6, p. 2094-2118, doi: doi.org/10.1130/GES01501.1.

Southwick, D.L., 1974, Geology of the alpine-type ultramafic complex near Mount Stuart, Washington: Geological Society of America Bulletin, v. 85, p. 391-402.

Surpless, K.D., Sickmann, Z.T., and Koplitz, T.A., 2014, East-derived strata in the Methow basin record rapid mid-Cretaceous uplift of the southern Coast Mountains batholith: Canadian Journal of Earth Sciences, v. 51, p. 339-357, doi:10.1139/cjes-2013-0144. 
Tabor, R.W., Waitt, R.B., Frizzell, V.A., Swanson, D.A., Byerly, G.R., and Bentley, R.D., 1982, Geologic map of the Wenatchee 1:100,000 quadrangle, central Washington: United States Geological Survey Miscellaneous Investigations Series Map I-1311, 26 p., scale 1:100,000.

Tabor, R.W., Frizzel, V.A., Vance, J.A.; and Naeser, C.W., 1984, Ages and stratigraphy of lower and middle Tertiary sedimentary and volcanic rocks of the central Cascades, Washington-Application to the tectonic history of the Straight Creek fault: Geological Society of America Bulletin, v. 95, p. 26-44.

Tabor, R.W., Waitt, R.B., Jr., Frizzell, V.A., Whetten, J.T., Waitt, R.B., Swanson, D.A., Byerly, G.R., Booth, D.B., Hetherigton, M.J., and Zartman, R.E., 1987, Geologic map of the Chelan 30-minute by 60-minute quadrangle, Washington: United States Geological Survey Miscellaneous Investigations Series Map I-1661, 33 p., scale 1:100,000.

Tabor, R.W., Haugerud, R.H., and Miller R.B., 1989, Accreted Terranes of the North Cascades Range, Washington: American Geophysical Union, v. T307, 62 p.

Tabor, R.W., Frizzell, V.A, Jr, Booth, D. B., and Waitt, R. B., Jr., 2000, Geologic map of the Snoqualmie Pass 30-minute by 60-minute quadrangle, Washington: U.S. Geological Survey Miscellaneous Investigations Map with pamphlet, $50 \mathrm{p}$.

Tabor, R.W., Booth, D.B., Vance, J.A., and Ford, A.B., 2002, Geologic Map of the Sauk River 30-minute by 60-minute Quadrangle, Washington: U.S. Geological Survey Scientific Investigations Map 2592, 2 sheets, scale 1:100,000, 1 pamphlet, 67 p.

Taylor, S.B., 1985, Stratigraphy, sedimentology, and paleogeography of the Swauk Formation in the Liberty area, central Cascades, Washington [M.S. thesis]: Pullman, Washington State University, 199 p.

Taylor, S.B., Johnson, S.Y., Fraser, G.T., Roberts, J.W., 1988, Sedimentation and tectonics of the lower and middle Eocene Swauk Formation in eastern Swauk Basin, central Cascades, central Washington: Canadian Journal of Earth Science, v. 25 , no. 7 , p. $1020-1036$.

Umhoefer, P.J., and Miller, R.B., 1996, Mid-Cretaceous thrusting in the southern Coast belt, British Columbia and Washington, after strike-slip reconstruction: Tectonics, v. 15 , p. 545-565, doi: 10.1029/95TC03498.

Walker, N., and Brown, E.H., 1991, Is the southeast Coast Plutonic Complex the consequence of accretion of the Insular superterrane? Evidence from $\mathrm{U}-\mathrm{Pb}$ zircon geochronometry in the northern Washington Cascades: Geology, v. 19, p. 714717, doi: 101130/00917613(1991)019<0714:ITSCPC>2.3.CO;2. 


\section{APPENDICES}

\section{Appendix A: Geochronology Sample UTM Locations}

Table A. 1: UTM locations of dated samples taken from the Swauk and Chumstick formations. UTM's are in zone 10, NAD83.

\begin{tabular}{cccc} 
Sample & Area & UTM & Elevation (ft) \\
\hline FS147 & upper Tronsen Ridge & 0682311,5252088 & 4486 \\
FS145 & upper Tronsen Ridge & 0682523,5251113 & 3985 \\
FS140 & lower Tronsen Ridge & 0682827,5250378 & 3789 \\
FS280 & Ruby Creek-Windmill & 0676993,5257382 & 2420 \\
FS253 & Point & 0696865,5241401 & 4510 \\
\hline
\end{tabular}




\section{Appendix B: Sample point counting data}

Table B. 1: Detailed mineral percentage modes based on point counts for all samples in the Swauk and Chumstick formations. Three hundred grains were counted and normalized to $100 \%$.

\begin{tabular}{|c|c|c|c|c|c|c|c|c|c|c|c|}
\hline & $\begin{array}{c}\text { Sample } \\
\text { FS }\end{array}$ & $\begin{array}{c}\text { Quartz } \\
(\%)\end{array}$ & $\begin{array}{c}\text { Feldspar } \\
(\%)\end{array}$ & $\begin{array}{c}\text { Biotite } \\
(\%)\end{array}$ & $\begin{array}{c}\text { Muscovite } \\
(\%)\end{array}$ & $\begin{array}{c}\text { Sedimentary- } \\
\text { Chert (\%) }\end{array}$ & $\begin{array}{c}\text { Metamorphic } \\
(\%)\end{array}$ & $\begin{array}{c}\text { Mafic } \\
\text { Volcanic (\%) } \\
\end{array}$ & $\begin{array}{c}\text { Felsic Volcanic } \\
(\%)\end{array}$ & $\begin{array}{c}\text { Miscelaneous/ } \\
\text { Unidentified/ } \\
\text { Cement (\%) }\end{array}$ & $\begin{array}{c}\text { Total } \\
(\%)\end{array}$ \\
\hline \multirow[t]{7}{*}{ Swauk } & 280 & 49 & 25 & 4 & 0 & 4 & 6 & 4 & 3 & 5 & 100 \\
\hline & 151 & 68 & 14 & 7 & 0 & 0 & 1 & 7 & 0 & 3 & 100 \\
\hline & 149 & 52 & 16 & 7 & 0 & 9 & 10 & 0 & 0 & 6 & 100 \\
\hline & 147 & 57 & 22 & 4 & 1 & 1 & 8 & 2 & 2 & 3 & 100 \\
\hline & 140 & 40 & 25 & 8 & 0 & 5 & 5 & 5 & 7 & 5 & 100 \\
\hline & 224 & 36 & 28 & 5 & 0 & 6 & 3 & 6 & 10 & 6 & 100 \\
\hline & $224 \mathrm{~A}$ & 42 & 24 & 4 & 0 & 5 & 2 & 6 & 5 & 12 & 100 \\
\hline \multirow[t]{2}{*}{ Chumstick } & 13 & 80 & 8 & 6 & 6 & 0 & 0 & 0 & 0 & 0 & 100 \\
\hline & 253 & 34 & 35 & 10 & 1 & 5 & 4 & 1 & 3 & 7 & 100 \\
\hline
\end{tabular}

